\title{
Article
}

\section{Enforcing Civility and Respect: Three Societies}

\author{
James Q. Whitman ${ }^{\dagger}$
}

\section{CONTENTS}

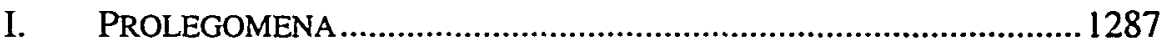

II. THE GERMAN CULTURE OF INSULT ....................................... 1295

III. THE ROOTS OF THE LAW OF INSULT IN PREMODERN SOCIAL HIERARCHY

IV. HATE SPEECH AND INSUlT BETWEEN "HONOR" AND "HUMAN DIGNITY"

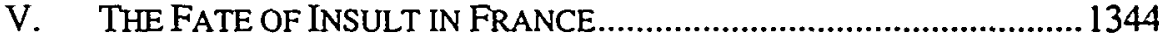

VI. NONLEGAL REGULATION IN FRANCE ......................................1361

VII. THE AMERICAN CASE............................................................... 1372

VIII. LEVELING UP/LEVELING DOWN............................................... 1384

IX. EXCURSUS ON VIOLENCE AND MODERN HONOR CULTURES........1391

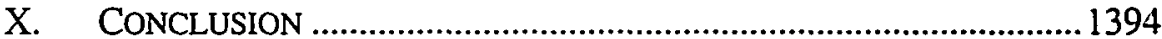

$\doteqdot$ Ford Foundation Professor of Comparative and Foreign Law, Yale Law School. Earlier versions of this Aricle were presented to the Law and Society Association and to workshops at the European Institute, Florence; Louisiana State University Law School: Yale Law School: and the University of Connecticut Law School. I am grateful to participants at all these fora for their comments. I would also like to acknowledge gratefully the comments of Bruce Ackerman, Mary Anne Case, Nikolas Eschen, George Fletcher, Daniel Gordon. Christian Joerges, Dan Kahan, Kar! Klare, Friedrich Kübler, William Miller, Rober Nye, Roben Post, Danicl Statman, and Reinhard Zimmermann. I benefited from the research assistance of Delphine Gaultier de la Ferritre, and most especially that of Gabrielle Friedman. I am also grateful to my European friends Olivier Beaud, Florence Bellivier, and above all Ines Stahlmann, who tried to teach me how to behave. This Article was originally prepared as part of a tribute to Lawrence Friedman. and I am glad. finally, to acknowledge not only his advice, but also his inspiration. Except where noted, translations are my own. 
It has become common, over the last decade or so, to plead for more "civility" and "respect" in American daily life. Some of this has come from politicians. Mayor Giuliani of New York, in particular, has been pushing the idea that more everyday civility can lower the urban crime rate. ${ }^{1}$ Newspapers and T.V. newsmagazines have suggested the same thing. ${ }^{2}$ At the same time, civility has become a favorite subject for academics, with books and articles written by philosophers, ${ }^{3}$ sociologists, ${ }^{4}$ historians, ${ }^{5}$ linguists, ${ }^{6}$ and lawyers. ${ }^{7}$ Two special topics have particularly engaged the attention of law professors: hate speech and sexual harassment. More "civility" and "respect" have been proposed as a solution to the problems of both. ${ }^{8}$ All in all, ideas that used to seem a little schoolmarmish in the wake of the 1960s-ideas about the enforcement of decent behavior-have come to seem respectable again, both politically and intellectually.

It is hard not to feel, though, that there is something utopian about much of this literature. America is a place where interpersonal relations have always been a bit rough by comparison with many other parts of the world. ${ }^{9}$ Introducing civil behavior into America-especially into places like New York City-means trying to root out what really seem like deepseated tendencies in American society. Maybe this can be done. But it is not easy to feel confident, especially since most of our literature is weak when

1. See Crime in America: Defeating the Bad Guys, THE ECONOMIST (American ed.), Oct. 3, 1998, at 35; Crime in the Subways Declines Again, N.Y. TIMES, May 14, 1999, at B3; New York City Mayor Giuliani Talks About His Efforts To Increase Civic Virtue, IOWA ST. Dally, Nov. 16. 1998 , at 1. On other aspects of the civility campaign, including the "civility retreat" for members of Congress, see generally Bayou Schools May Mix Math with Manners, CHRISTIAN SCI. MONITOR, June 21, 1999, at 1. For Louisiana legislation requiring "good manners" in schools (for example, addressing teachers and school administrators "by using the respectful terms 'Yes, Ma'am' and 'No, Ma'am' or 'Yes, Sir' and 'No, Sir'") in part as a response to the Columbine High School shootings, see Schools Look Hard at Lockers, Shirts, Bags, and Manners, N.Y. TIMES, May 24, 1999, at Al.

2. See, e.g., Crossfire: Giuliani Declares Civil War on Incivility (CNN television broadcast, Feb. 27, 1998).

3. See, e.g., Avishai Margaltr, The Decent SOciety (Naomi Goldblum trans., 1996); Sarah Buss, Appearing Respectful: The Moral Significance of Manners, 109 ETHICs 795 (1999).

4. See, e.g., EDWARD SHLS, THE VIRTUE OF CIVILITY (Steven Grosberg ed., 1997).

5. See, e.g., Kenneth Cmiel, The Politics of Civility, in THE SIXTIES 263-90 (David Farber ed., 1994).

6. See, e.g., Deborah TANNEN, You JuSt DON'T UNDERSTAND (1990).

7. See, e.g., RICHARD L. ABEL, SPEAKING RESPECT, RESPECTING SPEECH (1998); STEPHEN CARTER, CIVILITY: MANNERS, MORALS AND THE ETIQUETTE OF DEMOCRACY (1998); ROBERT Post, CONSTITUTIONAL DOMAINS (1995); Robert C. Post, The Social Foundations of Defamation Law: Reputation and the Constitution, 74 CAL. L. REV. 691 (1986).

8. See ABEL, supra note 7, at 262-63; Anita Bernstein, Treating Sexual Harassment with Respect. 111 HARV. L. REV. 445 (1997); Rosa Ehrenreich, Dignity and Discrimination: Toward a Pluralistic Understanding of Workplace Harassment, 88 GEO. L.J. 1 (1999) (emphasizing the dignitary harm of sexual harassment).

9. See KenNeth CMIEL, DEMOCRatic Eloquence: THE Fight over Popular SPEech in NINETEENTH-CENTURY AMERICA $69-70$ (1990); JOHN F. KASSON, RUDENESS AND CIVILITY: MANNERS IN NINETEENTH-CENTURY URBAN AMERICA 64, 138 (1990); ROBERT WIEBE, SELFRULE: A CULTURAL HISTORY OF AMERICAN DEMOCRACY 45-47, 49-50 (1995). 
it comes to explaining the deep workings of the sociology of civility. What, after all, is really involved in introducing "civility" into a given society? Why do some societies manage to do it, while ours fails?

It is with these questions in mind that I want to try, in this Article, to bring some comparative law to bear on the civility problem. Within our swelling civility literature there has not been much in the way of careful comparative law. To be sure, a kind of pop comparativism has been a minor motif in the literature. In particular, writers concerned with the problems of hate-speech regulation like to mention that other countries find it easier than ours does to regulate "uncivil" hate speech, and they have produced a variety of lists of the countries that do so. ${ }^{10}$ Other, more vague, comparative claims have also been made. France in particular, we have been told, with its patterns of courtesy and respect, is a more "mature" or more "civilized" place than the United States. ${ }^{11}$

But it has to be said that these comparative observations have been made in a naïve way. Authors generally summarize the cold black letter of foreign "hate-speech" laws without saying much about how those laws are applied in practice. Moreover-and more importantly - they make no effort to explain how or why the regulation of civility appears in some societies and not in others. ${ }^{12}$ It is all well and good to remark that foreigners regulate hate speech. Before we cite foreign statutes in any discussion of American law, though, we really need to know more. We need to know how hatespeech regulation, which seems so objectionable in the United States, came to seem acceptable elsewhere. We need to know, more generally, how the very idea that the law can regulate ordinary interpersonal relations could establish itself in some societies, but not in others.

10. See, e.g., POST, supra note 7, at 9 (citing Canada and listing authors who have compared the United States to other countries); Bradley Appleman. Hate Speech: A Comparison of the Approaches Taken by the United States and Germany, 14 WIS. INT'L LJ. 422 (1996): Sionaidh Douglas-Scott, The Hatefulness of Protected Speech, 7 WM. \& MARY BLL RTS. J. 305 (1999) (U.K., France, Germany); Credence Fogo-Schensul, More than a River in Egypt, 33 GoNz L. REV. 241, 267-69 (1997) (Canada, Germany); F. Haiman, Words That May Injure. 28 FREE SPEECH Y.B. 8 (1990) (France); Kenneth Lasson, Group Libel Versus Free Speech, 23 DUQ. L. REV. 77, 88-89 (1984) (Sweden); Mari J. Matsuda, Public Response to Racist Speech, 87 MiCH. L. REv. 2320, 2346-48 (1989) (U.K., Canada, Australia, New Zealand, Sweden); Mayo Moran, Talking About Hate Speech, 1994 WIS. L. REV. 1425 (Canada); Stephen J. Roth. The Legal Fight Against Anti-Semitism-Survey of Developments in 1993 and 1994, 25 ISRAEL Y.B. HUM. RTS. 349 (1995).

11. See Thomas Nagel, Concealment and Exposure, 27 PHL. \& PUB. AFF. 1, 9 n.4 (1998) (describing France, in contrast to the "regressed" United States, as a "postadolescent civilization").

12. For articles that try to penetrate a litule deeper, though from a point of view very different from mine, and focusing on Canada, see Kent Greenawalt. Free Speech in the United States and Canada, LAW \& CONTEMP. PROBS., Winter 1992, at 5; Kathleen Mahoncy. The Canadian Constitutional Approach to Freedom of Expression in Hase Propaganda and Pomography, LAW \& CONTEMP. PROBS., Winter 1992, at 77: and Moran, supra note 10. 
Hence the problem that I tackle in this Article. My focus is on the contrast between two highly "civil" Continental traditions-those of France and Germany-and the notoriously "uncivil" tradition of the United States. Both France and Germany are countries that are cited, admiringly, for their hate-speech regulation. France in particular is often noted for the high development of its norms of politeness. These countries are cultural near-neighbors of the United States whose social and political systems are in many ways not all that different from our own. They offer themselves naturally for an in-depth comparison. How did these countries, which in many ways closely resemble the United States, come to differ from us in matters of "civility"?

The effort to answer that question plunges us into a sea of complex problems in comparative sociology and history. Part of what I want to show is that European hate-speech regulation, in Germany in particular, is less far-reaching than American authors sometimes like to imagine. But my main interest is in tracing larger patterns in civility regulation than hate speech alone. The relative willingness of the Germans and the French to regulate hate speech is only a part of a more wide-ranging tradition of civility regulation in both countries. In neither France nor Germany is it right to view hate-speech regulation in isolation from other patterns of behavior, for in both countries, the regulation of hate speech is only one aspect of a more complex cultural pattern of the maintenance of respectful interpersonal relations. "Respect" matters over the whole landscape of law and society in Germany and France. In Germany, as we shall see, it may even be a criminal offense to call somebody a "jerk" or to give somebody "the finger": Germany has not only hate-speech regulation, but also civility law of a more far-reaching kind. France, for its part, is rich in widely accepted and carefully inculcated civility norms. The great challenge, in the effort to understand the comparative civility of the "civil" civil societies of France and Germany, is to understand how the values of "respect" and "civility" came to have this much more sweeping importance than they have ever attained in American law.

In addressing that challenge, this Article touches on a range of difficult questions in the sociology of law. But it focuses upon one thing in particular-something that will seem quite strange to most Americans: the idea of the protection of personal honor. In both Germany and France, "honor" is a protectable legal interest $;{ }^{13}$ and in both of those countries the maintenance of norms of civility is closely linked to the maintenance of a general right to what German scholars sometimes call "a minimum of

13. On France, see, for example, BERNARD BEIGNIER, L'HONNEUR ET LE DROIT (1995): and ANDRÉ Vitu, Traité de Droit CRIMINEL: Droit PÉnal SPÉcial 1577-78 (1982). 
honor" 14 or "a certain minimum standard of personal respect." is Rude behavior is regarded in both countries as an assault on the personal honor of its target, in a way that Americans would find difficult to comprehend. It is the German and French legal cultures of honor that present the mystery that is my principal topic in this Article: How did it come to pass that honor, a concept regarded by most Americans as almost laughable, has survived in the large industrial democracies of Continental Europe?

Explaining that survival, it turns out, is not entirely easy to do. There is, to be sure, a literature on European honor and dignity. In particular, commentators frequently point to the European commitment to generalized personal honor as part of a larger reaction against the horrors of the Fascist period. This is particularly true of accounts of the German hate-speech regime. As Eric Stein, for example, describes it:

In the Federal Republic of Germany...the Basic Law (Grundgesetz) guarantees freedom of opinion and speech but makes it expressly subject to limitations defined in "the general laws, the provision of law for the protection of youth, and by the right to inviolability of personal honour." The experience with the abuse of freedoms that contributed to the demise of the Weimar Republic and the suppression of these freedoms by the National Socialist regime left a deep imprint upon the Basic Law and subsequent legislation .... [As a consequence of that experience,] free speech claims must be weighed against the values of human dignity and personal honor that are grounded in the Basic Law itself. ${ }^{16}$

Reading this passage, and many comparable ones, ${ }^{17}$ one might think of the European attachment to dignity and honor as the work of the postwar period. Europeans, one might suppose, try to enforce "respectful"

\footnotetext{
14. RALF STARK, EHRENSCHUTZ IN DEUTSCHLAND 26 (1996).

15. RUDOLPH MACKEPRANG, EHRENSCHUTZ IM VERFASSUNGSSTAAT 268 (1990).

16. Eric Stein, History Against Free Speech: German Law in European and American Perspective, in VERFASSUNGSRECHT UND VOLKERRECHT: GEDÄCHTNISSCHRIFT FOR WILHELU KARL GECK 831-32 (Wilfried Fiedler \& Georg Ress eds., 1989) (footnotes omitted). An carlicr version of this article appeared in 85 MICH. L. REv. 277 (1986). Cf. Fricdrich Kubler. How Much Freedom for Racist Speech?, 27 HOFSTRA L. REV. 335. 336 (1998) ("Specific laws against racist hate speech are largely a product of the second half of the iwentieth century. In par. their origins are shaped by the specific national experience. This is particularly obvious in Germany, where its approach is primarily dictated by the trauma of the Holocaust.").

17. Many post-1945 constitutions included provisions guarantecing "social dignity" or "human dignity" that were clearly intended to mark the end of the Fascist era. See infra note 354 and accompanying text. Human rights lawyers similarly explain and justify the campaign for human rights that is so vigorously proseculed in the European Court of Human Rights in Strasbourg as the product of the horrific experience of Fascism. Even the new French law on bioethics has been presented to the world as a safeguard against Fascism. See Richard Saltus, France Weighs Restrictive Biomedical Science Law. BOSTON GLOBE, Oct. 23, 1993, at 6 (stating that Justice Lenoir, a top French jurist, ascribes the restrictiveness of French biocthics law to "memories of Nazi racial and genetic practices").
} 
interpersonal relations because Europe went through a hell of human indignity in the 1930s and 1940s that America escaped. Correspondingly, one might suppose that the European law of honor and dignity had to do with great issues of human rights. One might draw the same conclusions from some of the commentaries on European law that present the idea of dignity as a realization of the philosophy of Immanuel Kant and of the ideals of the Christian tradition; ${ }^{18}$ European lawyers, one might guess, have been horrified by the Nazi experience and have felt compelled to turn to high moral philosophy.

Yet, as I argue in this Article, no such account of the rise of European dignitary law can be more than partially correct. First of all, the European law of honor is by no means exclusively about great issues of human rights. To the contrary, the European culture of honor and dignity reaches very deep into everyday social life, covering what to us seem astoundingly trivial matters of civility. Germany and France are not just countries with law on politically charged matters like hate speech. They are countries where ideas of honor and respect govern a striking range of human interaction. They are countries with cultures of respect that form the deep sociological context of their law of respect.

Moreover, they are countries whose cultures of respect are palpably much older than 1945, and whose laws of respect rest on some very unKantian values. Indeed, as this Article argues, the honor-laden civility environments of both France and Germany must be traced back principally to the aristocratic cultures of the eighteenth, and to some extent the nineteenth, centuries. The honor associated with civil behavior was, in earlier periods, a characteristically aristocratic value; and when people in both countries behave "civilly" today, they do so, in large part, by adopting patterns of behavior that were once characteristically aristocratic patterns. The post-Fascist period is a latecomer in the making of law safeguarding European dignity. Indeed, the role of Fascism itself in the making of the European culture of honor is, I suggest, complex and ambivalent: The Nazis, in point of fact, far from hindering the generalization of honor in German society, were largely responsible for establishing that all Germans (though of course not all persons; and of course only those "Germans" who matched the Nazi definition) had a legally cognizable share of social honor. As for Kantianism and Christianity, while they have certainly exercised a postwar influence on European dignitary law, it is an influence, as I try to show, that has often failed to reach terribly deep.

The notion that the culture of legal dignity is simply a post-Fascist development in Europe, straightforwardly drawn from the traditions of high moral philosophy, thus will not do. Explaining French and German respect

18. See infra note 167 and accompanying text. 
requires us to reach deeper into everyday life, and deeper into the European past, than that.

Reaching into everyday life and the European past is accordingly what this Article undertakes to do. This Article describes the dignitary cultures of civility that reign in both France and Germany today and traces the sources of those cultures to old traditions of social hierarchy: The "personal honor" that is now the possession of every European, I will show, is modeled on what was once aristocratic honor. Even European hate-speech regulation is a product of this history, for hate-speech regulation in both countries grows, strangely enough, out of a tradition of dueling law, which historically aimed to guarantee the honor of the aristocratic classes, as well as out of a tradition of law of deference, or law obliging social inferiors to show respect to their betters. When Jews and other outsiders receive the protection of the laws in France and Germany, they are, in effect, being treated as honorary aristocrats. The same is also true, I suggest, of developing European sexual harassment law: The tendency in Europe has been to build a dignitary law of sexual harassment that is quite different in spirit from what we have here. In the heritage of the laws of dueling and deference, and in other aspects of French and German dignitary law as well, we see the continuing strength of an aristocratic tradition that is simply missing in the United States. To echo a famous claim of Louis Hartz, the United States is a place where, in contrast to Continental Europe, the "feudal ethos" has not exercised a formative influence, ${ }^{19}$ and that has made a profound difference.

This difference is one that I try to capture in a large sociological generalization: France and Germany, I argue, have witnessed, each in its own way, leveling up. In both societies, the cultural memory of an age of social hierarchy is strong, and the commitment to modern egalitarianism has been a commitment to the proposition that all persons should stand on the highest rung of the social hierarchy. Egalitarianism in France and Germany is an egalitarianism that proclaims we are all aristocrats now; and in practice this has been an egalitarianism of widely generalized norms of civil respect. American egalitarianism, by contrast, is, I suggest, an egalitarianism of leveling down, which proclaims, in effect, that there are no more aristocrats - that we all stand together on the lowest rung of the social ladder. One consequence is that this egalitarianism of the lowest rung has often proven to be an egalitarianism of lack of respect.

This is, I want to emphasize at the outset, a somewhat disheartening conclusion for those who would like to see more civility in the United States. Germans and French show respect for others now, I argue, principally because they continue to profit from a tradition of social

19. See LOUIS HARTZ, THE LIBERAL TRADITON IN AMERICA 4 (1955). 
hierarchy. We in the United States do not have, and generally do not want, any such hierarchical tradition, and that makes the prospects for more civility here a bit dimmer.

A few further introductory words about the aims of this Article are in order. Civility is a topic that straddles the realms of "law" and "society," and inevitably much of this Article will consist of detailed discussion of the interrelationship between "legal" and "social" regulation in both Germany and France. Indeed, it is part of my goal to show that law and socicty interpenetrate in complex ways in both of those countries. With regard to Germany, I show that the technically defined law of civility has stimulated and informed a wide-ranging "legal culture" of civility, whose prescriptions go well beyond the provisions of the law itself. With regard to France, I show that, while the technically defined law of civility has largely vanished, the social norms of politeness that govern French society are nevertheless largely modeled on the law, making heavy and revealing use of legal terminology and concepts. In tracing all of this, I hope to give us a deeper grasp of the abidingly difficult problem of the social impact of narrowly legal ideas.

I also hope to make something of a contribution to the theoretical sociological literature, and, especially in the closing analytic sections of this Article, I measure my argument against the ideas of some of our leading sociological authorities on interpersonal interaction-in particular, Erving Goffman, Norbert Elias, Hume, and Tocqueville. I also address one paradoxical issue that grows out of our standard literature on "honor cultures": the issue of violence. Most of our accounts of honor cultures assume that a strong attachment to honor brings with it high rates of social violence. Yet the opposite is the case in Continental Europe. I make, in a brief Part, some effort to explain why.

Part I of this Article briefly makes some preliminary analytic distinctions: between civility and decency; between civility rules requiring an outward show of respect and civility rules requiring a sincere acknowledgment of the equality of others; and between the legal protection of reputation and the legal protection of honor. Part II describes the remarkable German legal culture of insult, under which disrespectful expressions like "jerk" can be criminally penalized and hate speech is regulated. This Part also touches on something called the law of "sexual insult," which theoretically guarantees respect for women in Germany. As this Part shows, Germans participate in a kind of popular legal culture of "insult" that extends well beyond the technical coverage of the law. Part III traces the roots of the contemporary German law of insult to their sources in the law of dueling and deference. Part III also discusses something disturbing: the importance of the Nazi period in the critical generalization of norms of civil respect in Germany. Part IV discusses the current state of 
German law, in which old values of personal honor continue to haunt efforts to build a new jurisprudence of "human dignity."

Parts V and VI turn to France. In Part V, I describe the decline of the French law of insult after the eighteenth century. France has today a merely vestigial law of insult, which serves as the basis for French hate-speech regulation, but which has not produced anything like the German legal culture of insult described in Part II. France does, however, have a lively and vigorous culture of politesse, or norms of politeness. In Part VI, I describe that culture of politesse, showing that it too has roots in aristocratic tradition and in the terminology and conceptual repertoire of the old law of insult. Part VI also emphasizes that while France has only a vestigial law of insult, it has a vigorous tradition of teaching civility in the schools: In France, education does some of the work that law does in Germany. In Part VII, I briefly describe the absence of a law of civility in the United States.

The final three Parts of this Article present my conclusions. Part VIII makes a broad argument for the decisive importance of aristocratic tradition in the making of the respect-oriented cultures of Germany and France, invoking some of the classic social-scientific claims of figures like Hume and Elias. Part IX tackles some of the difficult problems raised by the relationship between honor and violence. Part $X$, finally, assesses the impact of this research for our thinking about civility regulation here in the United States.

Making my case will require some dense historical detail, including a foray deep into the Nazi period. The reader will, I hope, be patient. By the end of the Article, I hope to have convinced the reader of the importance of these different traditions of egalitarianism for the making of relations of civility. One thing I am not able to offer is any clear answer on the advisability or the prospects of a law of civility in the United States. But I do mean to offer, by the end of the Article, a clearer sense of just what is at stake in any campaign to introduce civility regulation into the United States.

\section{PROLEGOMENA}

Everyday American life can seem extremely abrasive, and the yearning for more "civility" in America is easy to understand. So is the desire to make the law somehow a tool for "civilizing" American society. It is entirely natural to look abroad for models for any American civility program. When we look abroad, though, what do we see?

We might expect to see no law of civility at all. There is a tradition, as old as Aristotle, that holds that matters of civility are never a proper field for legal regulation. It was Aristotle's view (at least in one famous passage) 
that people who "say mean things out of cussedness" are not any concern of the theory of justice, narrowly and properly understood. ${ }^{20}$ This tradition, holding that rudeness is no concern of the law, has been especially strong since the eighteenth century, ${ }^{21}$ and it remains strong today. It is a tradition that is, of course, particularly strong in the United States, where the assumption that "mere rudeness" cannot be legally regulated pervades our discussions of both hate speech and sexual harassment. Nor is it Americans alone who imagine that rudeness is just plain unregulable: The legal literatures of all major Western countries declare that there is a category of behavior that is "merely rude"-behavior that, though it may be objectionable and nasty, gives rise to no legal liability. ${ }^{22}$ Such behavior may run afoul of the rules of civility, but those rules are social rules and not legal ones.

This is such a widespread notion that it may seem surprising that anything that could be called a law of civility should be accepted in the democratic West, or indeed in any part of the world. Yet in point of fact, there is plenty of what can fairly be called law of civility. Indeed, Aristotle himself (writing in other, less famous, passages) had no doubt that some kinds of disrespectful statements ought to be penalized. ${ }^{23}$ Even in the modern Western democracies, one can find law that penalizes what to Americans seem stunningly trivial instances of rudeness.

Here it is important to begin, though, by making three often-neglected analytic distinctions. The first is the distinction between two aspects of "good manners" - what I will call civility and decency. By civility, in this

20. ARISTOTLE, ETHICA NiCOMACHEA 98 (1130a) (Franciscus Susemihl ed., Teubner $3 \mathrm{~d}$ ed.

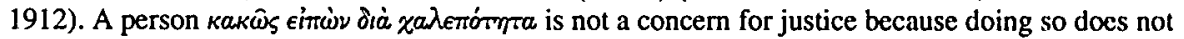
involve taking more than one's share. This hardly means that Aristotle thought "honor" was not a good that should be correctly distributed in society, of course. See id. It means only that, in this passage at least, he doubted that mere harsh words counted enough to be a subject of concern. For a survey of later literature on this topic through the 17th century, see Manfred Beetz, Ein neuentdeckter Lehrer der Conduite: Thomasius in der Geschichte der Gesellschaftsethik, in CHRISTIAN THOMASIUS 1655-1728, at 199, 209 n.60 (Werner Schneiders ed., 1989).

21. On the particularly important contribution of Christian Thomasius, who distinguished among three types of good, the "justum," the "decorum," and the "honestum," where decorum served to characterize rules of civility that stood outside the reach both of the law and of morality properly understood, see Frederick M. Barnard, Rightful Decorum and Rational Accountability: A Forgotten Theory of Civil Life, in CHRISTIAN THOMASIUS 1655-1728, supra note 20, at 187; Beetz, supra note 20, at 199; and Hinrich Rüping, Theorie und Praxis bei Christian Thomasius, in CHRISTIAN THOMASIUS 1655-1728, supra note 20, at 137,139 . The classic statement of the modern view is to be found in Rousseau, Lettre a d'Alembert sur les spectacles, discussed in James Q. Whitman, What Is Wrong with Inflicting Shame Sanctions?, 107 YALE L.J. 1055, 1086 \& n.142 (1998).

22. See, e.g., EMILE WORMS, Les ATtENTATS A L'HonneUR 169 (n.p., Perrin 1890) (“"Il va de soi ... que de simples impolitesses, des faits de discourtoisie ne constituent pas, mais en raison seulement de leur insignifiance, des offenses qui peuvent être évoquées par le droit."). For Germany and the United States, see infra notes 66, 327, 330 and accompanying text.

23. See N.R.E. Fisher, Hybris: A STUDY IN THE VAlues of HONOR and SHAME iN ANCIENT GREeCE 7-35 (1992); Douglas M. MaCDOWELl, THE LAW IN CLASSiCAL ATHENS 130 (1978). 
Article, I mean strictly the practices that involve showing respect to others. These practices include forms of address (the use of "Sir" and "Madam," vous and Sie), forms of deportment (bowing, shaking hands), and other forms of deference such as yielding to another on the street; they also include refraining respectfully from telling ethnic jokes or indulging in ethnic slurs. By decency, in contrast, I mean practices that aim to avoid giving offense or calling attention to gross or bestial aspects of life. The practices of decency include such things as the maintenance of delicacy in table manners, restraint from exposing one's nudity, and refusal to use obscene expressions in public. Civility and decency are routinely lumped together under the heading of "good manners," 24 yet they involve two fundamentally different aspects of social life. As a moment's reflection will show, the psychological drives that underlie civility and decency differ: The urge to show or demand respect is importantly different from the urge to cover one's nakedness or to cover one's mouth when eating or yawning. Civility and decency are, moreover, addressed to very different audiences. As Rudolf von Jhering pointed out more than a century ago, the practices of civility are always directed at some particular person or persons considered as having a particular defined status: We always show respect for somebody. The practices of decency, by contrast, are never directed at anybody in particular. They restrain our behavior vis-à-vis an undifferentiated public. ${ }^{25}$ Not least, civility and decency presuppose different underlying problems of social structure. Rules of civility speak, as a general matter, to problems in the maintenance of hierarchical social order among human beings; rules of decency speak, as a general matter, to problems in differentiating the human from the bestial. Civility and decency are of course related. When one wants to show disrespect, for example, one

24. The failure to distinguish between the two is a fault that infects even, and especially, the leading work on the subject of civility, Norbert Elias's The Civilizing Process. Elias's argument, summarized infra note 381 and accompanying text, purports to analyze the history of "good manners." See NORBERT ElLAS, THE CIVILLING PROCESS 42-178 (1994). In fact. Elias addresses almost exclusively questions of decency, not questions of civility.

Something of the same fault also weakens William Miller's superb exploration of the realm of decency, The Anatomy of Disgust. The least persuasive chapter in Miller's book aims to link the experience of disgust with social contempt for inferiors. See WILLAAs IAN MILLER. THE ANATOMY OF DISGUST 206-34 (1997). That sort of social contempt is something that I show here is more closely linked with norms of civility than with norms of decency. Miller has expressed his own doubts about the relation between contempt and disgust. See id. at 218 . In saying this. I do not mean to deny that decency and civility should ultimately be analyzed together. I mean only to say that much more care in argument is required before disrespect and disgust can be shown to reduce to the same social-psychological force.

25. See 2 RUDOLPH VON JHERING, DER ZWECK M RECHT 281-83 (Hildesheim 4th ed. 1970) (1905) (distinguishing Höflicllkeit, Anstand, and Takt, which may, in the context of his discussion, be translated as civility, decency, and tact); id. at 288-89 (distinguishing decency from Höflichkeit); id. at 379 (observing that civility, unlike decency, always involves some contact with another individual). 
often uses indecent expressions. ${ }^{26}$ Nevertheless, it is critically important to keep the two distinct, especially when speaking of the law. There is law of civility and there is law of decency. The two have different purposes and appear in different societies in different measures.

Within the category civility, moreover, it is important to make a further distinction, between rules that require what can be called the outward show of respect and rules that call for the sincere acknowledgment of the equality of others. The outward show of respect is the form of "civil" interaction that is invariably discussed in our philosophical and sociological literature on good manners. The stuff of the outward show of respect is direct interaction between two individuals, the deployment of polite forms of address (such as "Sir," "Madam," "Your Grace," or "Your Majesty"), polite inquiries (such as "How are you?" and "How are [various members of your family]?"), polite formulas attached to the exchange of goods or services ("Thank you," "much obliged," or "your servant"), and polite deportment. The little drama of the show of respect is something that has fascinated a number of philosophers, who have analyzed it as a highly unusual form of ethical interaction-a form in which truth-telling carries no positive value.

The show of respect is, indeed, a realm of socially sanctioned lying: One is being most polite when one disguises one's actual lack of respect for another. As Hume put it, in analyzing "the rules of GOOD MANNERS OF POLITENESS" as part of his Enquiry Concerning the Principles of Morals: "Among well-bred people, a mutual deference is affected: Contempt of others disguised: Authority concealed: Attention given to each in his turn: And an easy stream of conversation maintained, without ... eagerness for victory, and without any airs of superiority." ${ }^{27}$ To Jhering, similarly, the forms of civility, which give the lie to the affectation that goodness always involves truth-telling, are a species of dolus bonus, or "good deceit," where deceit would otherwise be a form of illegality. ${ }^{28}$ Most recently, Sarah Buss has revived the same line of thought in an article pointedly titled Appearing Respectful. ${ }^{29}$ To all of these authors, the world of civility is a remarkable arena of mere appearances-and of routinely false appearances. This oddly positive valuation of a species of hypocrisy manifests itself, moreover, in the kind of remedy that we demand when the rules of the outward show of respect are violated: We demand a ritualistic apology. In demanding an apology, though, we do not imagine that

26. See Charles P. Flyni, InSUlt AND SOCIETY: PATtERnS OF COMPARATIVE INTERACTION 16-20 (1977) (surveying the evidence).

27. DAVId Hume, AN ENQUiRy CONCERNING THE PRINCIPLES OF MORALS 139 (Tom L. Beauchamp ed., 1998) (1751).

28. See 2 JHERING, supra note 25 , at $449-50,455$.

29. See Buss, supra note 3. 
apologies are always sincerely meant; apologies too can be hypocritical. This does not trouble us, however, because the realm of the outward show of respect is a realm of form and not of inner conviction, a realm of purely ritual self-abasement. The world of the show of respect, in Erving Goffman's terminology, is a world purely of ceremony, not of substance. ${ }^{30}$ The use of the apology as a remedy also reflects the character of the outward show of respect as involving interaction between two individuals. Because the victim of a failure to show respect has been insulted by one person, the wound to that victim's subjective sense of dignity can ordinarily be salved by an individual apology.

Civility has thus been routinely treated by philosophers as a form of individual interaction in a world of masks, or mere appearances. Yet, everyday experience tells us that there are forms of civility that we perceive precisely as reactions against the cheerful hypocrisy of the outward show of respect-forms of civility that, in a kind of dialectical opposition to ordinary politesse, call for ostentatious sincerity. In particular, Americans are all familiar with civility rules requiring the sincere acknowledgment of the equality of others. By these rules (which do not figure in the literature on good manners, but which matter immensely for our analysis of the problem of hate speech), I have in mind rules of a particular kind of respectful decorum-rules that generally forbid us to glory in the social inferiority of particular classes of persons. Such rules typically prohibit the use of ugly racial epithets and nasty ethnic jokes.

Unlike rules guaranteeing the outward show of respect, rules requiring the sincere acknowledgment of the equality of others do not necessarily involve direct interaction between individuals at all. On the contrary, it is a striking fact that it may violate those rules to tell an ethnic joke even when no individual who is a target of the joke is present at all. There is a reason for this: While the outward show of respect aims to create or affirm a ritual relationship of respect between two individuals, the sincere acknowledgment of the equality of others aims to create or affirm a deeper dignitary structure for society at large. This contrast is manifested in the sort of remedy called for by a breach of rules requiring the sincere acknowledgment of the equality of others. Because the victim of an ethnic slur has been confronted by a larger social pattern of disrespect, an individual apology will typically do little to restore his or her subjective sense of dignity. It is small comfort to the victim to hear what may seem a "merely polite" or hypocritical disavowal of prejudiced views. On the contrary, the victim tends to wish that the joke-teller would undergo some sort of transformation of inner state of mind-some experience of

30. See ERVING GOFFMAN, The Nature of Deference and Demeanor, in INTERACTION RITUAL 47, 53 (1967). 
conversion or reeducation. This highlights a revealing, and very large, contrast between these two kinds of rules. While a kind of hypocrisy is in the spirit of the outward show of respect, the drive of rules requiring the sincere acknowledgment of the equality of others is precisely to root out hypocrisy. Substance, and not ceremony, does matter here. Indeed, one of the most deeply felt injuries of those who complain about the absence of a social commitment to dignity equality is the injury occasioned by hypocritical shows of tolerance. (This suggests that advocates of the apology as a remedy for offensive hate speech, such as Richard Abel, ${ }^{31}$ have not fully considered the underlying phenomenology of the kind of disrespect involved.)

This distinction, between rules requiring the outward show of respect and contrary rules requiring the sincere acknowledgment of the equality of others, has been neglected in our secondary literature. Yet it deserves some careful emphasis. In particular, I am going to suggest in this Article that the law of civility that we find in Continental Europe tends to embody rules guaranteeing the show of respect. This has some dramatic consequences. Because this outward show of respect model of civil relations dominates in German law, for example, German jurists, as we shall see, may discern no violation of norms of respect in the posting of a sign that reads "No Turks Allowed," or even in the act of a German man who grabs the breasts of a woman passing in the street.

Alongside these distinctions in the nature of good manners, we must, finally, distinguish between two legal interests: the legally protectable interest in reputation and the legally protectable interest in honor. The interest in reputation is an interest in making sure that shameful or discreditable things about us do not become public knowledge. The interest in honor is an interest in making sure that other people show us respect, not only in the public sphere, but also in private settings. These two are quite different. The difference between them can be extremely difficult for American lawyers to grasp, however, because in the United States, we generally protect only reputation. Thus, our strong tendency is to protect individuals against nasty statements only through our law of defamation: We tend to penalize such statements only if they injure reputation, which means that they must normally reach the ears or eyes of someone other than the person defamed. Correspondingly, our tendency, in discussing hate speech, is to imagine a law of group "libel" or group "defamation." 32

31. See ABEL, supra note 7, at 265.

32. See Lasson, supra note 10; David Riesman, Democracy and Defamation: Control of Group Libel, 42 COLUM. L. REV. 727 (1942); David Riesman, Democracy and Defamation: Fair Game and Fair Comment I, 42 CoLUM. L. REv. 1085 (1942). This is the approach to be found in Beauharnais v. Illinois, 343 U.S. 250 (1952), as well. Some confusion, arising from a failure to understand the logic of honor, is also to be seen in DAvid GARRIOCH, NEIGHBORHOOD AND 
Continental European law and the law of many other parts of the world that protect honor differ in ways that lead them to imagine different kinds of law. The difference shows itself most dramatically in the existence of what German and French lawyers call the "law of insult" - a species of law that the United States fundamentally lacks. ${ }^{33}$ The law of insult does not concern injuries to reputation. What it involves, instead, is shows of disrespect. The law of insult is pure law of civility in the sense in which I just defined it: It penalizes disrespectful words, gestures, and the like. In the countries in which it exists, the law of insult is regarded as concerning injuries not primarily to reputation, but to personal honor or dignity. Accordingly, there is no requirement that legally cognizable insults ever reach the ears or eyes of any third party; it is a sufficient assault on a person's dignity to have been addressed in a disrespectful or contemptuous manner, regardless of whether any third party has witnessed the event. ${ }^{34}$ Moreover, since disrespect and contempt are at stake in the law of insult, legally insulting statements or gestures, unlike defamations, do not typically include any allegation of fact. Most legal "insults" simply involve expressions of contempt, such as "you swine" or "you jerk," or gestures of contempt, such as "the finger." Such words and gestures of contempt cannot be said to include imputations of fact in any meaningful way. ${ }^{35}$ The existence of a law of insult is, moreover, only the most dramatic example of the way in which legal systems that protect honor can differ from legal systems that protect reputation. France and Germany also differ from the United States

COMMUNITY IN PARIS, 1740-1790, at 40 (1986). Garrioch understands insults to affect reputation and puzzles over what harm many cases of insult could have occasioned.

33. The difference goes strikingly unnoted even in the European literature, in which law of Beleidigung is routinely translated as "law of defamation" without discussion of the decp-scated differences that are my topic in this Article. See, e.g.. GEORG NOLTE, BElEIDIGUNGSSCHUTZ IN DER FREIHEITLICHEN DEMOKRATIE 3 (1992).

34. For an example of the failure of even the very finest American imagination to see that there can be a law of honor that does not require publication to a third party, see Post, supra note 7 , at $710-11$.

35. The difference between the law of defamation and the law of insult can be usefully illustrated with an example from the world of American hate spcech. If a white American, out of the hearing of third parties, calls a black American "nigger," there is no legal defamation. Because the white American has expressed personal contempt for the black American, however. there might be a legal insult under German law.

It is also possible to draw another valuable distinction, though it is not one that I pursue in this Article. This is the distinction between the law of insult, narrowly understood, and the law of deference. The law of deference is also concerned with maintaining respect. But the object of the law of deference is to guarantee the maintenance of social hierarchy in a socicty in which a welldefined social hierarchy exists. Typical law of deference, of the kind we find in many premodern societies, may require, for example, that social inferiors always yield to social superiors on the street. An example is the law of medieval Islam, which required members of tolerated minority religious groups to yield to Muslims in just that way. See, e.8.. JOSEPH SCHACrT. AN INTRODUCTION TO ISLAMIC LAW 131 (1964). Law of deference is exclusively concemed with relations between persons who are not status-equals: All law of deference involves relations between lower-status persons and higher-staus persons. This distinguishes the law of deference from the law of insult, which typically involves relations between status-equals. 
in their law of defamation. For in both France and Germany, defamation law is regarded as protecting both reputation and honor. ${ }^{36}$ As we shall see, this has some very important consequences for the analysis of defamatory statements in both France and Germany.

Understanding the distinction between honor and reputation is critical for the analysis of the law of civility. Both law protecting honor and law protecting reputation can be thought of as regulating "rude" behavior in some sense. Nevertheless, it is really law protecting honor that matters most for the establishment of a law of civility. When American authors complain that we lack law of civility, they do not mean that we lack law protecting reputation. We do have such law. They are complaining that we lack law protecting honor-law that aims specifically to protect individual dignity by maintaining forms of respect. When I speak of the "law of civility," accordingly, I mean law protecting honor-law whose purpose is to guarantee respectful interaction.

With these distinctions made, we can say that law of civility does exist. Despite the widespread notion that rudeness can never be legally regulated, the law of civility is, in fact, found in many parts of the world; Aristotle's "people who say mean things" are penalized in many places. ${ }^{37}$ Some of this is informal and therefore hard to detect. We shall see, for example, that in France some civility norms have historically been enforced through discretionary police action, whose exact contours may be difficult to identify. Some civility regulation also probably goes on informally in the litigation process: It is fair to guess that litigants who act in "polite" ways sometimes receive more favorable treatment than litigants who do not. ${ }^{38}$ But there is also civility regulation that consists of formal legal rules of the ordinary kind. Formal legal rules of civility are particularly common in legal systems founded on hierarchical principles. Confucian systems, for example, include elaborate regulation of polite interaction between persons of different statuses; societies that set great store by maintaining formal hierarchical relations typically have a great deal of law regulating deference. $^{39}$

36. See Jeanne M. Hauch, Protecting Private Facts in France: The Warren \& Brandeis Tort Is Alive and Well and Flourishing in Paris, 68 TUL. L. REV. 1219, 1236 (1994) (discussing the law of defamation in France); Peter E. Quint, Free Speech and Private Law in German Constitutional Theory, 48 MD. L. REV. 247, 297-98 (1989) (discussing the German law of defamation).

37. For some (unfortunately unsystematically gathered) anthropological data. see FLYNN. supra note 26 , at $69-76$.

38. Presumably, for example, litigants in defamation cases both in the United States and abroad receive better treatment, and perhaps are subjected to lower damage awards. if they apologize or otherwise present themselves as "civil" persons.

39. See, e.g., Geoffrey MacCormack, The SpIRIT Of Traditional Chinese Law 100-86 (1996). For (again unsystematic) observations from a variety of world cultures on the connection between rules of insult and social hierarchy, see FLYNN, supra note 26, at 34-36, 39-53. For the 
But formal legal regulation also exists in the egalitarian West. While every Western system declares that "mere rudeness" is not sanctionable at law, the fact is that Western systems define "rudeness" in quite various ways. The consequence is that it is often possible to point to law, in a given country, that from the outsider's point of view can only be said to regulate "rudeness."

\section{THE GERMAN CULTURE OF INSULT}

One remarkable example of such rudeness regulation is the German law of Beleidigung, or "insult," and it is with the German law of insult, and more broadly with the German legal culture of civility, that I would like to begin. ${ }^{40}$

Americans are aware that Germany has one of those more "civil" Continental societies against which we might want to measure our own. Much of what makes German society seem so "civil" is a matter of easily observed social regulation. Linguistic forms play an especially prominent role. Everyday rituals of linguistic respect-the use of forms of address like Herr and Frau, for example-are perhaps not as common in Germany as they are in France, but they are certainly more common than they are in the United States. Germans are indeed famous for their affection for complex honorifics such as Herr Professor Doktor. One intricate set of German civility problems is completely unfamiliar in America: the constellation of sociolinguistic problems surrounding the use of the formal Sie- "you"rather than the informal $d u$ - "thou." These problems play a large role in everyday interaction in Germany. ${ }^{41}$ Germans are also, as foreign visitors to Germany often remark, more apt than are either Americans or the French to express loud and vocal disapproval of those who violate community norms. The cry of unverschämt! - "what shameless behavior!" - is familiar to all savvy travelers as a part of the local civility climate in Germany. ${ }^{42}$

focus on deference in American slave codes, see BERTRAM WYATT-BROWN, SOUTHERN HONOR: ETHICS AND BEHAVIOR IN THE OLD SOUTH 363 (1982).

40. There is some terminological confusion that should be dealt with immediately. Beleidigung in German law is used in two senses: as the general term for law not only of insult strictly understood, see \$ 185 STRAFGESETZBUCH [StGB] [criminal code] (F.R.G.). but also of defamation, slander, and certain other crimes, see id. § 186 (defamation); id. $\$ 187$ (slander); id. $\S 187$ a (political defamation); id. $\$ 189$ (abuse of the memory of deceased persons). Here, for clarity's sake, I use "insult" only in its strict sense, as applied to \$ 185 SiGB.

41. The ordinary German rule is that the status-superior "offers the $d u$ ": that is to say, the status-superior has the option of inviting the status-inferior to enter a relationship in which the two parties address each other as $d u$. This rule can of course run up against difficulties where it is unclear which of the two is the status-superior. In certain settings. especially among students, saying $d u$ is normal. For a typical etiquette-book discussion, see INGE FALKEN. KLEINES LEXIKON DER MODERNEN UMGANGSFORMEN: VON ABENDANZUG BIS ZUHOREN $35-36$ (1998).

42. As nicely observed at the opening of Dutch author Cees Nooteboom's Berlijnse Notities, 
Where German society differs most strikingly from both French and American, though, is in the degree of its legal regulation of civility behaviors. It is of course a famous fact that hate speech-racial "insult," in German legal analysis ${ }^{43}$ - has been subject to dramatic legal regulation since the collapse of the Nazi regime. ${ }^{44}$ What goes unremarked, though, is that the law of insult reaches far beyond the problem of hate speech. The general law of insult penalizes a whole range of behaviors that seem to foreigners much less naturally "illegal" than hate speech does. Indeed, it distorts the German law of insult to speak as though it were just about hate speech. That law establishes something much grander: a kind of general law of interpersonal respect.

Respect is indeed the critical operative concept. The German law of insult criminalizes words, gestures, or behavior that show Mißachtung oder Nichtachtung, "disrespect or lack of respect" for another. Most famously, in German everyday culture, the law of insult criminalizes a gesture called "the bird" : the tapping of the index finger on the forehead. "The bird" is a gesture used by one car driver to indicate that another is mentally defective. ${ }^{45}$ In my experience, every German knows that it is illegal to make "the bird." In fact, every German knows that anybody who is the target of any such gesture-for example, "the finger" or "the fig" ${ }^{46}$ - has the right

Als ik voor de deur van mijn nieuwe huis aangekomen ben krijg ik ecn herhalingsoefening. Ik heb de auto nog niet neergezet om mijn bagage en mijn boeken voor het komende halfjaar uit te laden of er gaat een raam open en van bovenaf begint een oude man te schreeuwen over unverschämt. Ik ben thuis.

As I arrive at the door of my new house I get a lesson. Before I have finished pulling my car over to unload my bags and books for the coming half year a window opens above me and an old man starts to carry on about unverschämt. I'm home.

CEES NOOTEBOOM, BERLIJNSE NOTITIES 8 (1990).

43. German hate-speech regulation also includes the crime of Volksverhetzung, which I will explore below.

44. For a description of the German law of insult in the context of the politically charged questions of hate speech, see Quint, supra note 36, at 319, which discusses hate speech, and Mathias Reimann, Prurient Interest and Human Dignity: Pornography Regulation in West Germany and the United States, 21 U. MICH. J.L. REFORM 201, 233 (1988), which discusses insult directed toward women as a group. These discussions do not touch on the deeper culture of insult that is my topic here. See also Edward J. Eberle, Public Discourse in Contemporary Germany, 47 CASE W. RES. L. REV. 797, 862 (1997) (briefly mentioning the law of insult).

45. On "the bird," see HANS-GEORg DOERING, BElEIDIGUNG UND PRIVATKLAGE 23, 38 n.2 (1971); on "the bird" and "the double bird," see ANDREAS HOHNEL, "DOPPELVOGEL" UND ANDERE BELEIDIGUNGEN 25-26, 28 (1997). I am most grateful to Dr. Hohnel, who provided me with a copy of this book. For another view, see HAMBURGER ABENDBLATT, Feb. 19, 1999, available in <http://www.abendblatt.de/contents/ha/news/lokales/html/190299/ 1702RARE2.HTM>, excerpted infra note 52. Surprisingly, Doering found that traffic was actually rare as the setting for insults. The most frequent setting, during the 1957-1965 period studied in his monograph, was the common area of an apartment building. See DOERING, supra, at 15.

46. On "the finger"-nicely known as the Stinkefinger in German-see HOHNEL, supra note 45, at 26. "The fig" falls under the same jurisprudence, described infra notes 68-70 and accompanying text. 
to call the cops. I have more than once had conversations with Germans along the following lines:

American: You mean it's illegal to make a gesture like that in Germany?

German: You mean it's not illegal in America? ${ }^{47}$

Nor is it gestures alone that are criminalized by the German law of insult. Words fall under the same set of prohibitions: It can be a criminal offense in Germany to call another person a "jerk," or even to use the informal $d u$, or "thou." ${ }^{48}$ Clearly enough, there are differences, and indeed chasms of difference, between Americans and Germans.

But to understand what those differences are, and how deep they run, we have to read carefully in the literature of German law. We have to read carefully, in particular, because the problem is not just what the law of insult says, but what ordinary German people think the law of insult says. The German law of insult belongs, as I want to show, to a much larger German culture of insult, a culture in which the law encourages and reinforces popular values that often differ from the values enshrined in the law itself. This means that we must read our texts with scrupulous care, looking for evidence that takes us beyond the words of the text itself.

Going beyond the words of the text itself is in any case unavoidable, since the text of the criminal provision on insult is remarkably un-selfexplanatory. The German provision on insult appears in the criminal code next to the provisions on defamation and slander. ${ }^{49}$ It is unlike almost any

47. I cite, as one example among many, my conversation with Professor Reinhard Zimmermann, of the Universität Regensburg, in New York City (Mar. 21, 1998). For an example of American surprise at German practices, see FLYNN, supra note 26, at 79, describing a traffic citation for "the bird."

48. See infra note 53 and accompanying text

49. As noted supra note 40 , there is terminological confusion in the use of Beleidigung; in particular, some statistical reporting lumps them together, especially $\S \S 185-187 \mathrm{StGB}$. While this gives rise to some analytical difficulties, it is important to note that $\$ 185$ actions dwarf others in the case law. See Klaus Geppert, Straftaten gegen die Ehre, 10 JuRA 530 (1983). Also relevant to the general law of Beleidigung is $\$ 213$ StGB, which provides for lesser penalties for offenders whose homicides have been "provoked" by an insult. For recent cases, see Bundesgerichtshof [BGH] [Supreme Court], Oct. 22, 1997, 3 StR 394/97, JURIS ref. no. KORE535709800 (F.R.G.); BGH [Supreme Court], Neue Juristische Wochenschrift [NJW]. 40 (1987). 3143 (F.R.G.).

Civil actions are also possible. In paricular, and of very long standing, are demands for Unterlassung (an injunction forbidding the defendant to repeat the insult) and Widernif (a court order of retraction, not expressly permitted under the Code but employed by the courts anyway). For a discussion with references, see Friedrich Kubler, Offentlichkeit als Tribunal, 39 JURISTEN ZETTUNG [JZ] 541, 542 (1984). For comparable American "retraction" statutes, see MARC A. FRANKLIN \& ROBERT L. RABIN, CASES AND MATERIALS ON TORT LAW AND ALTERNATIVES 940-41 (3d ed. 1983). More broadly, the increased availability of civil damages under postwar jurisprudence, see infra note 174 and accompanying text, has presumably removed some litigants from the criminal docket to the civil. See, e.g., MACKEPRANG. supra note 15, at 251-52 
other provision of German criminal law in its opacity, criminalizing insults without making any effort at defining them:

StGB $\S 185$ : Insult is punished by imprisonment for a term of up to one year or by a fine, and, where the insult is made by means of physical assault [mittels einer Tätlichkeit], by a term of up to two years or by a fine.

This provision, which might well be deemed unconstitutionally vague in the United States, ${ }^{50}$ has to be read in Germany against the background of a large body of scholarly commentary. It also has to be "read," as it were, against a body of social practice; for it is clear, even in the case law, that popular ideas about the import of $\S 185 \mathrm{StGB}$ differ from scholarly ones.

And popular ideas can matter in the German law of insult in a very direct procedural way. Insult is one of a class of mostly minor offenses that give rise to a Privatklage, or a private criminal prosecution. ${ }^{51}$ This means that criminal prosecutions of insult are typically brought by the insulted private parties themselves. ${ }^{52}$ The consequence is that the aspects of German

(suggesting that one of the most important developments in honor-protection law since the enactment of the Basic Law may be the transfer of disputes from the criminal to the civil arena).

50. Some German scholars have indeed suggested that the statute is the cquivalent of voidably vague-in violation of the principle nulla poena sine lege as established by GRUNDGESETZ [GG] [Constitution] Art. 103 Abs. 2 (F.R.G.). See STARK, supra note 14, at 139 \& nn.30-31.

51. Section 374 Strafprozeßordnung [StPO] [Code of Criminal Procedure] (F.R.G.) makes a Privatklage available, without any requirement of a prior involvement of the state's attorncy. in cases involving (1) trespass into the home; (2) insult; (3) bodily harm; (4) threats; (5) corruptibility or actual corruption in commercial affairs; (6) damage to goods: (7) unfair competition; and (8) a variety of matters of infringement of intellectual property.

52. Under $\S 376 \mathrm{StPO}$, the state's attorney may also bring actions in insult cases that affect the public interest. Complainants, it should be noted, may also have a civil action under the German law of the protection of personality. See infra note 60 and accompanying text.

For a guide for the public on how to bring private prosecutions, see Justiz Bchörde Hamburg [Hamburg Justice Authority], Hamburgischer Rechtswegweiser (visited Dec. 3, 1999) <http:// www.hamburg.de/Behoerden/JB/hhrecht/strat 2 .html $>$. For a newspaper article presenting the law to the public, see HAMBURGER ABENDBLATT, supra note 45 :

Teure Beleidigungen

Was kostet die "Blöde Kuh"?

Gerade wochentags setzen sich viele Autofahrer gestreßt hinter das Lenkrad. “Bloß nicht zu spät kommen", denken sie. Aber Hindernisse wie Mïllwagen. Baufahrzeuge oder Unfallwagen lassen in Hamburg oft schnell einen Stau entstehen. Dann wird gehupt, gedrängelt, überholt und geflucht. Aber aufgepaßt: Belcidigungen können teuer werden! Wer Anzeige erstattet, weil er sich durch Gesten oder Schimpfwörter beleidigt fühlt, kann Erfolg haben. Nicht strafbar ist der "Doppelvogel", wenn man mit zwei Fingern an die Schläfe tippt. Richter haben aber Autofahrer zu 2200 Mark Strafe verurteilt, weil sie den "Stinkefinger" gezeigt haben. Auch für die Ausdrücke "Blöde Kuh", "Schlampe" oder "Brillenschlange" mußten schon 150 Mark bezahlt werden.

Teurer ist es, Polizisten zu beleidigen. Wer sie als "Holzkopf" oder "Trottel in Uniform" beschimpft, kann zu Strafen von 1500 bis 3000 Mark verurteilt werden

Diese Vergehen wirken harmlos gegenüber Angriffen anderer Art. Da wurde schon mit Schreckschußpistolen und Gasrevolvern geschossen, es kam zu Priigeleien 
life that I began by describing as part of the social civility culture also belong to a culture of German criminal litigation. A glance at a standard commentary on German criminal law gives a sense of the odd range of actions that can end up in court. Particularly interesting are actions brought in cases in which one person has called another $d u$-the familiar "thou"rather than Sie-the formal "you." ${ }^{53}$ Such actions sometimes (but only sometimes!) fail, but the very fact that they are brought suggests that the popular conception of what counts as legally sanctionable lack of respect or disrespect goes far. Failed actions have also been brought in cases in which one person has declined to address another as Herr or subjected another to rude jokes; in cases in which one neighbor has thrown pebbles against the window of another; in which one person has watched two others exchange

und Messerstechereien zwischen Autofahrem. Dann versuchen Gerichtc, der Aggression Einhalt zu gebieten, indem sie den Führerschein entzichen und Fahrvertote aussprechen. Verkehrspsychologen raten, sich von aggressiven Autofahrem nicht provozieren zu lassen.

\section{Expensive Insults}

What Does "Stupid Cow" Cost?

Especially on weekdays, many drivers get behind the wheel. and get stressed. "Just get there on time," they think. But obstacles like garbage trucks, construction vehicles, and emergency vehicles often produce an abrupt traffic tie-up in Hamburg. That's when people start honking, shoving, passing each other, and cursing. But better watch out: Insults can get expensive! People who file a complaint with the police, because they feel that they've been insulted through gestures or nasty languagc, can have success. "The double bird" - tapping on your temples with two ningers-is nor subject to plinishment. But judges have fined drivers $2200 \mathrm{DM}$ [S1150] for giving " the finger." Expressions like "stupid cow," "slut," or "Mrs. Four-Eyes" have had to be paid for with $150 \mathrm{DM}[\$ 80]$.

It's expensive to insult police officers. Anybody who calls them "blockhead" or "idiot with a badge" can be sentenced to fines of 1500 to 3000 DM [S790-S1580].

These minor offenses seem harmless when compared to other sorts of altacks. There have been shootings with warning pistols and tear-gas guns; encounters between drivers have escalated into fist-fights and knife-fights. In these cases, courts try to put a stop to the aggression by suspending driver's licenses and banning drivers from the road. Traffic psychologists advise that you not let yourself get provoked by aggressive drivers.

53. See R. Keller, Zur Frage unter welchen Umständen der Gebrauch des Wortes 'Du' bzw. 'Dich' als Beleidigung des anderen anzusehen ist, in Oberlandesgericht [OLG] [Court of Appeals for Dusseldörf], Juristische Rundschau [JR], (1990), 345 (F.R.G.). These cases, which have such cultural resonance, show up in labor law as well. For a recent case, sec Arbeitsgericht [ArbG] Rheine [Labor Court for Rheine], Jan. 10, 1998, JURIS ref. no. KARES22820536 (F.R.G.). In this case, an employee at a clothing retailer that required all employees to say du brought an unsuccessful action demanding to be addressed as Sie. For others, sce Bundesverwaltungsgericht [BVerwG] [Federal Administrative Court], Neue Zeitschrift für Verwaltungsrecht [NVwZ], 18 (1999), 659 (659-63) (F.R.G.) (abuse of female soldiers by a superior, including addressing them as $d u$ ); BVerwG [Federal Administrative Cour] 1. Disziplinarsenat. July 9. 1991, I D 72/89, JURIS ref. no. WBRE310452302 (F.R.G.) (same); and BverwG [Federal Administrative Court). Oct. 23, 1974, JURIS ref. no. WBRE002558400 (F.R.G.) (inappropriate use of $d u$ by a workplace superior). For an older example, see, for example. HoHNEL, supra note 45, at 7-8, discussing a case in which a Duala tribesman brought suit in 1915 for having been addressed as du: the case was at first dismissed by the lower court on grounds that black Africans have no expectation of being addressed as Sie. It was then reversed on appeal. Surprisingly, there were only two such cases in Doering's sample. See DoERING, supra note 45, at 26. 
affectionate gestures in public; and more. ${ }^{54}$ The phenomenon of these unsuccessful actions, all involving what to us seem rudenesses of an uncommonly mild kind, suggests something noteworthy about the German law of insult: Like the American law of sexual harassment, it leads a shadow life in the popular mind. To understand the reach of both types of rudeness regulation, we must accordingly track their impact in the world of popular belief about the law-in the world of ordinary people like so many of my German acquaintances who think they know that obscene gestures are illegal $;{ }^{55}$ in the world of ordinary people like the many Americans who are sure that any workplace flirtation may count as sexual harassment.

It would be a mistake, however, to focus only on unsuccessful private actions for insult; the successful ones can be pretty striking too. The German legal profession does have a much narrower definition of "insult" than the general population seems to have. In fact, legal officials, both state prosecutors and judges, as well as scholars, make vigorous efforts to limit the actual reach of the law of insult. The law of German criminal procedure is designed to make the bringing of private criminal prosecutions for insult burdensome, which undoubtedly cuts down on the number of cases that get to court. ${ }^{56}$ Indeed, while many insult complaints are filed, the number of cases actually litigated to judgment in Germany is exceedingly small $;{ }^{57}$ under pressure from the legal profession, insult has become a species of law with a far richer life in the popular mind than in the courts. ${ }^{58}$ In the

54. See Bayerisches Oberstes Landesgericht [BayObLG] [Bavarian Court of Appeals]. JR (1963), 468 (F.R.G.) (throwing stones at windows); BayObLG [Bavarian Court of Appcals], JR (1980), 1969 (F.R.G.) (observation of affectionate gestures); Reichsgericht [RG] [Imperial Supreme Court], Juristische Wochenschrift [JW], (1936), 2997 (2998) (F.R.G.) (practical joke); RG [Imperial Supreme Court], Leipziger Zeitschrift für deutsches Recht, (1915), 446 (F.R.G.) (failing to say Herr). These are the examples given in SCHONKE-SCHRODDER STRAFGESETZBUCH $\S 185$, at 1386 (Theodor Lenckner et al. eds., 25th ed. 1999) (F.R.G.) [hereinafter SCHONKESCHRÖDER].

55. Of course, the causes of action brought in court can represent only a fraction of the cases that Germans believe are "illegal." See infra note 58.

56. For a discussion of the difficulties, see Geppert, supra note 49, at 530-31. Complainants are obliged to post a bond for the costs of the trial. See $\$ 379$ StPO. More importantly, they may be subjected to an award of the costs and fees of the other party. See id. $\S 383$, Abs. 2 (permitting dismissal); id. $\S 470$, Abs. 3 , Ziff. 2 (permitting an award of costs and fees). Doering nevertheless found that courts almost always split costs and fees equally between the parties pursuant to $\S 471$. Abs. 3, Ziff. 2 StPO. See DOERING, supra note 45 , at 86.

Litigants are, finally, obliged to submit to mediation before bringing their claims. See $\S 380$ StPO. For a full discussion, see LOWE-ROSENBERG, GROßKOMMENTAR STRAFPROZEBORDNUNG 72-77 (Peter Rieß et al. eds., 25th ed. 11 th Supp. 1999) [hereinafter LOWE-ROSENBERG]. For the Ehrenerklärung, the formal apology typically delivered at the end of a German mediation, sec DOERING, supra note 45 , at 108.

57. For figures and discussion, see LÖWE-ROSENBERG, supra note 56, at 15.

58. In the city of Berlin, for example, the number of complaints and citations has grown substantially over the last decade, even as the efforts of the legal profession have kept all but a fraction of those cases from being litigated to judgment. Unfortunately, the categorics used in reporting insult cases are irregular and shifting. Nevertheless, some information can be gleaned from the reported data. The city of Berlin has reported cases of Beleidigung under two different headings since 1989: polizeilich bekanntgewordene Straftaten (criminal acts that have come to the 
substance of the law of insult, too, the scholarly literature asserts insistently that the law of insult does not extend to "mere rudeness"-bloße

attention of the police-all complaints and citations) and convictions, reported for the ycars 1989 1992. These figures do not distinguish among the various types of Beleidigung in $\$ \$ 185-189$. See supra note 40 and accompanying text. Nevertheless, historically it is $\$ 185$ cases that have overwhelmingly predominated. See DOERING, supra note 45, at 69; see also Günter Bierbrauer el al., Conflict and Its Senlement: An Interdisciplinary Srudy' Concerning the Legal Basis, Function and Performance of the Institution of the Schiedsmann, in 2:1 ACCESS TO JUSTICE 66, 67 (Mauro Cappelletti \& John Weisner eds., 1978) (discussing the prevalence of Beleidigung cases). Nevertheless, both the figures for complaints and citations and the figures for convictions are revealing. The figures for all reported complaints and citations show a remarkable and steady increase since 1991, the first year for which there are consolidated figures for the unified city of Berlin:

\begin{tabular}{|c|c|}
\hline YEAR & $\begin{array}{c}\text { NUMGER OF REPORTED } \\
\text { COMPLAINTS AND CITATIONS }\end{array}$ \\
\hline 1989 & 8545 \\
\hline 1990 & 8023 \\
\hline 1991 & 10.234 \\
\hline 1992 & 11.996 \\
\hline 1993 & 13.077 \\
\hline 1994 & 13.868 \\
\hline 1995 & 16.151 \\
\hline 1996 & 16.254 \\
\hline 1997 & 17.908 \\
\hline
\end{tabular}

Sources: Statistisches Landesamt Berlin: Statistisches Jahrbuch Berlin; 1990-1998.

This represents a 75\% increase in insult citations and complaints during the first seven years after reunification. (The population of Berlin in this period held roughly constant, declining slightly from $3,447,695$ in 1990 to $3,425,759$ in 1997. with a high of $3,475,392$ in 1993.) It is hard to know how to interpret this. Could it be a consequence of conflicts between former Eastemers and Westemers? At any rate, it certainly shows that Beleidigung remains alive and well in Berlin legal culture.

The figures for convictions in Berlin, for the years in which they are reported, also show a steady upward path:

\begin{tabular}{|c|c|}
\hline YEAR & NUMBER OF CONVICTIONS \\
\hline 1952 & 304 \\
\hline 1973 & 299 \\
\hline 1989 & 838 \\
\hline 1990 & 813 \\
\hline 1991 & 756 \\
\hline 1992 & 981 \\
\hline
\end{tabular}

Source: Statistisches Jahrbuch Berlin.

Most interesting about the figures for conviction, though, is the fact that they are dwarfed by the figures for complaints and citations. In 1992, only eight percent of complaints and citations resulted in a conviction. This comesponds exactly with the figure found by Doering in his empirical study of three German jurisdictions from 1957 to 1965. See DOERING. supra note 45, at 12. For the dates of his study, see $i d$. at 3 . The contrast with almost any other area of criminal enforcement is striking. Insult cases, these figures unmistakably show, belong more to the popular culture of insult than to the court system. For further discussion, see Bicrbrauer el al., supra, at 49-51.

Needless to say, many cases of perceived Beleidigung must go unreported. For what it is worth, ROBERT HEINDL, DER BERUFSVERBRECHER 220 (7th ed. 1928), suggested that one out of every 100 cases is reported. This estimate, cited approvingly by DOERING. supra note 45 , at 10, is at least evidence of a German conviction that there is a great deal of "criminal" insult going on. 
Unhöflichkeiten. ${ }^{59}$ Jurists also argue against the very idea that criminal law should be routinely used to protect piddling matters of "honor." German honor can also be vindicated through the law of "personality," a body of civil law that largely grew out of the law of insult ${ }^{60}$ and that permits money damages. ${ }^{61}$ Many commentators argue that insulted Germans should seek satisfaction in the law of personality, not in the strange species of criminal action represented by the law of insult. ${ }^{62}$

Yet the very tenacity with which jurists insist on setting limits to the law of insult testifies to the strength of the popular misconception that they are trying to combat. In both procedure and substance, the German law of insult presents the spectacle of the legal profession trying to ride herd on the general public, in order to corral strong popular beliefs about the existence of rights-and rights of such importance that they should be vindicated through the criminal law.

That is not to say, though, that professional German jurists are in principle unbendingly hostile to the law of insult. Even the small number of prosecutions that are allowed to proceed can seem pretty strange to the American reader. It is well to quote a current commentary at length in order to give a sense of the strangeness of even restrictive German juristic thought. The difficulty in interpreting the law of insult begins, for the commentator, in explaining what insult is. That must be done by reference to a concept of "honor" and of words and acts that "sully the honor," that are ehrenrührig:

The objective fact pattern justifying application of the statute requires an "insult." "Insult," which is not precisely described in the section ... is to be understood as an attack on the honor of another person...through expressions of lack of respect, low respect, or disrespect. Sections 186, 187 [that is, the law of defamation and slander] punish factual assertions, sullying the honor, which are communicated to third parties, and which therefore make it possible that their target will suffer the disrespect of third parties. Section 185, by contrast, covers the expression of the offender's own lack of respect for the victim, [and accordingly there need not be a communication of the "insult" to third parties]... . Such an expression of disrespect is possible in three different ways: (1) through the expression of an insulting judgment

59. See infra note 66 and accompanying text.

60. See DiETER LeUZE, DIE ENTWICKLUNG DER PERSÖNLICHKEITSRECHT IM 19. JAHRHUNDERT 75-80 (1962) (tracing carefully the limited influence of Roman actio injuriarum and limitations on its law of damages).

61. Money damages, however, have only been permitted since the 1950s. See infra note 174 and accompanying text.

62. See, e.g., Geppert, supra note 49 , at 531. 
of value made to the victim; (2) through the expression of such an insulting judgment of value made to a third party; and (3) through an assertion of fact, sullying the honor, made to the victim himself .... ${ }^{63}$

In practical terms, the matter turns on the ways in which one person can show lack of respect or disrespect for another. This principle serves to limit the reach of the law:

It is necessary that the offender express disrespect or lack of respect in the specific sense that the moral, personal, or social valuation or worth [Geltungswert] of the victim is wholly or partially denied through the ascription of negative qualities. In other words, there must be a claim that the victim is of lesser value or is inadequate under one of those three aspects [that is, moral, personal, or social valuation or worth].... It is thus an insult if the victim is reproached with immoral or illegal behavior, or if it is insinuated that the victim could engage in such behavior-though to be sure, only if the offender thereby expresses the view that the victim is to be valued as a person who is capable of such behavior - or if the victim's moral integrity is denied either generally or in regard to some specific tendency (for example, through the epithets "blackguard" [Lump], "thief," attempt at bribery). It is further an insult to reproach another person, despite that person's status as an intelligent being, with being inadequate in elementary aspects of humanity (for example, calling another person "idiot"...). Finally, it is an insult touching the social valuation and worth of the victim to refuse to acknowledge, in whole or in part, the victim's capacity to perform in his profession or in other social tasks that fall to him (for example, characterization of a doctor as a "bungler" ... ) ; it is, however, not an insult to deny that such a person deserves credit for particular achievements or services. ${ }^{\text {s }}$

In particular, the requirement of an expression of disrespect serves to limit the application of the law of insult in cases involving foreigners. Here and elsewhere we discover that the German law of hate speech does not go quite as far as its foreign admirers sometimes imply:

The mere rejection of another person is not an insult. For this reason, with regard to expressions of hostility to ethnic nonGermans [ausländerfeindlichen Äußerungen], it is a question of

63. OLG [Court of Appeals for Selected Matters], NJW, 38 (1985), 1720 (F.R.G.).

64. Id. 
interpretation whether there has also been an intent to express the view that the targeted person is of lesser value ... ; the same is true for refusals to admit certain groups of persons to bars, etc., which qualify as an insult only if they are to be understood as meaning that the owner of the establishment regards the targeted persons as unworthy of being served by him ([as is] the case, for example, in the exclusion of U.S. soldiers from a discotheque, where [those soldiers] saw through the pretense [that the establishment was filled to capacity]. ... In general, such refusals to admit are permissible only where they are made with a view to the needs of other clients, who otherwise threaten to stay away .... Refusals to admit Turks need not be regarded as an insult per se). ${ }^{65}$ statute:

At all events, "mere rudeness" is excluded from the coverage of the

Not sufficient for purposes of $\S 185$ are mere rudenesses and tactlessnesses, insofar as they do not take the form of a particularly coarse expression of disrespect. Petty harassment, inappropriate jokes, gags, and the like are insults only if they are accompanied by particular circumstances that express a view of the lesser value and worth of the affected party. ${ }^{66}$

All of this certainly must do a great deal to prevent claims of insult from succeeding. Yet the actions that the German legal profession endorses, under the standards of this and other literature, are still pretty remarkable from the American point of view. The popular German belief that obscene and derisive gestures-even mildly derisive gestures-are subject, in principle, to criminal prosecution is perfectly correct. In Hamburg, for example, people who give "the finger" routinely receive a fine of roughly $\$ 1150 .^{67}$ Many of the sorts of derogatory epithets that are heard all the time in the streets of New York (or, for that matter, any southern Italian city) are similarly subject to prosecution: for example, "asshole," 68 "jerk," "quack" (when used of a doctor), ${ }^{69}$ and "idiot." The list goes on and on, into

65. SCHÖNKE-SCHRÖDER, supra note $54, \S 185$, at $1385-86$. It is important to observe, however, that although the refusal to admit Turks to a bar is not necessarily insulting hate speech under German law, it may nevertheless constitute impermissible discrimination, as it would in the United States. For a fuller description and critique, see Volker Lohse, "Türken ist der Zutritt verboten"-Volksverhetzung durch Zugangsverweigerung, 29 NJW 1677 (1985).

66. SCHONKE-SCHRÖDER, supra note 54, at 1385-86.

67. See supra note 52.

68. See HOHNEL, supra note 45, at 24 (mentioning Arschloch ("asshole") and Wichser (or, as the British put it, "wanker")).

69. Cf. Amtsgericht [AG] Tiergarten [Local Court for Tiergarten], June 2, 1989, JURIS ref. no. KORE561279011 (holding that it is an insult to call an attorney a Möchtegern-Anwalt ("lawyer wannabe")). 


\author{
Rabelaisian dimensions. ${ }^{70}$ All in all, it is something of a paradise for fans of \\ Mayor Giuliani. Prosecutions are brought in circumstances that can only
}

70. The list of insults in Doering's sample is as follows:

Altes Aas ["old rotting carcass"], Ausbeuter ["exploiter (of the working classes)"], zugelaufener Ausländer ["foreigner on the run to Germany"], Affe ["monkcy"]. elender Asiat ["miserable Oriental"], scheeler August ["cross-eyed clown"], Arbeiterverräter ["traitor to the working class"], Bastard ["bastard"]. Butzemann ["bogeyman"], alter Bock ["old goal"], Biest ["beast"], aus den Nuhten platzende Bardame ["barmaid bursting out of her seams"], Brillenheini [" four eyes" - insulting term used of man wearing glasses; contrast "Brillenschlange," supra note 52], Brechmittel ["vomit-inducer"], schwuler Bruder ["faggot"], Drecksker [" filthy jerk"], Drecksau ["filthy sow"], Dreckschwein [" filthy swine"], Drecksbagage [" pack of filth"], Denunziant ["police informant"], Dussel ["twit"], Ehebrecher ["adulterer"], Erbschleicher ["born hypocrite"], Faulenzer ["lazy good-for-nothing"]. dummes Frauenzimmer ["dumb broad"], Flüchulingslumpenpack ["Iousy pack of refugees"], Flintenweib ["gun-toting woman"], Flegel ["ill-mannered boor"]. Fose ["cunt; prostiute"], Ganove ["thief"], verhindere Grafin ["would-be countess"], Giftnudel ["poisonous noodle"-roughly "shrew"]. Gesocks ["riff-raff"], dumme Gans ["dumb goose"], Gangster ["gangster"], alte Hexc ["old witch"], Hundertfüfundsiebziger ["hundred-and-seventy-fiver" - a reference to the nowrepealed $\$ 175$ of the Criminal Code, which criminalized homosexuality]. Hafenkneipenweib ["harbor joint girl"], Hure ["whore"], Hurentochter ["daughter of a whore"], Hurensohn ["son of a whore"], Hurenbalg ["whoreskin"], Hurenbulle ["whore cop"], Hurenbock [" whore goat"], Herumtreiberin [" tramp"], Hampelmann ["nebbish"], Halsabschneider ["cutthroat"], dummer Hund ["dumb dog"], Halunke ["scoundrel"], falscher Hase ["meat loaf"], halber Hund ["half dog"], Hinterlader ["faggot"], Idiot ["idiot"], Irrer ["lunatic"], griuner Junge [" greenhom"], Judenbengel ["Jew-brat"], Knallkopp ["fathead"], Kituchenbruder ["jailbird"]. deutscher Kartoffelbauch ["German potato belly"], Kupplerin ["female pimp"], Kuppelmutter ["female pimp in incarnation as mother-figure"], Kommunist ["communist"], Lauer ["lurker"], schäbiger Kerl ["shabby bastard"], dumme Kuh ["dumb cow"], großes Kalb ["big calf"], Kamel ["camel"], elender Kruppel ["miserable cripple"], Knastologe ["jailbird"], alte Krähe ["old crow"], Klinkenputzer ["beggar"]. Luder ["dits"], Liignerin ["liar" (female)], Lausebengel ["bral"], Lump [" scoundrel. blackguard"], Liigenschnauze ["trap full of lies"], Louis ["pimp; homosexual"], Lude ["pimp"], kleines Licht [" dim bulb"], Miststilick [" piece of dung"], schlechter Mensch ["bad person"], Mongolenweib ["mongol-woman"], Mensch zweiter Klasse [" secondclass human being"], Mißgeburt ["deformed creature"], Mistvich ["dung animal"]. Nutte ["hooker"], Nebelkrähe ["hooded crow"], Nitribit ["whore"], Nazischwein ["Nazi pig"], Nachtwächter ["dope"], Ochse ["ox"], Öfentliche ["whore"], Ostzonenschwein ["Soviet-zone-of-occupation pig"], Prolet ["proletarian"], Pimpf ["member of Hitler Youth"], Pöbel ["canaille"], Puffaltsche [" female overseer in a brothel"], gemeiner Polack ["common Polack"], Rotznase ["snot-nose"]. Sozialempfänger-Jule ["woman dependent on welfare"], Saubesen [" old sow"], Satan ["Satan"], unkameradschaftliches Schwein ["pig-who-does-not-act-like-a-comrade"]. altes, fettes Schwein ["old, greasy pig"], Schweinehund ["swine"], alte Schachtel ["old box"], Schürzenjäger ["skirt-chaser"], eingebildete Schnecgans ["conceited goose"], Schwanzzeiger ["penis-shower"], Scheißkollege [" fucking coworker"], Sau ["sow"], Saustiick ["piece of sow"], Saukerl ["sow-bastard"], Spitzbubc ["scoundrel"], Schuft ["cad"], Schubbejack ["shabby, low-class person"]. Strolch ["rogue"], Strichdame [" streetwalker"], Schnösel [" snot"], Sittenstrolch [" violator of good morals"], Schurke ["rogue"], Schlampe ["slut"]. Schreckschraube ["old battleaxe"], erotischer Schmutzfink ["dirty old man"]. Schandtier ["disgraceful animal"], dreckiges Stuick ["piece of shit"], Sonntagsjüger ["Sunday hunter"], Teufel ["devil"], alte Tucke [nasty word for a woman], Trampel ["oaf"]. Torikopf ["peat-head"]. Totengräber ["gravedigger"], Verbrecher ["criminal"], Vollidiot ["complete idiot"]. Vogelscheuche ["scarecrow"], Wildsau [" wild sow"], Witwenausnultzer [" exploiter of 
astound Americans: So strong is the culture of respect in Germany, for example, that prison inmates have brought prosecutions against guards who addressed them disrespectfully. ${ }^{71}$ Even political expressions that, in the United States, would clearly constitute protected free speech may be prosecuted as "insults" in Germany. The commentary I have quoted, like others, says only that the standards for prosecuting a political utterance must permit a "more robust use of speech" than is otherwise the case. ${ }^{72}$ These somewhat stiffer standards have not prevented politicians from being prosecuted for such faults as calling their opponents "liars." ${ }^{73}$ Such private prosecutions often succeed in the lower courts only to fail on appeal, ${ }^{74}$ and a bitter constitutional debate may-may-auger their demise. ${ }^{75}$ Nevertheless, Americans will see an incomprehensible insensitivity to the value of free speech in the very fact that these actions are brought at all and succeed on any level. Some deep-seated cultural differences are at work here: Ordinary

widows"], kleines Würstchen ["tiny little sausage"], Waschlappen ["sissy"], verkommenes Weib ["decayed broad"], Weihnachtsmann ["clown"-literally "Santa Claus"], Zigeunerbengel ["gypsy brat"], Zigeunerlottchen ["slovenly gypsy woman"]. Zuchthäusler ["convict"], alte Ziege ["old nanny-goat"], alte Zicke ["old nannygoat"].

DOERING, supra note 45 , at 26-27 n.1. Many more examples are given in greater detail in HOHNEL, supra note 45.

71. One noteworthy recent case, involving a question of constitutional law but reflecting the general German culture of insult, involved a transsexual inmate who sued successfully after being addressed by prison guards as "Herr" despite having undergone a sex-change operation. See Bundesverfassungsgericht [BVerfG] [Federal Constitutional Court], NJW, 50 (1997), 1632 (1633) (F.R.G.). Two other prison-related cases are described in DOERING, supra note 45, at 15, cases in which prison inmates initiated complaints pursuant to $\S 185 \mathrm{StGB}$ against guards, in one case because the guard called the prisoner a "dumb beast." This is a wonderful study that shows. among other things, where cases of Beleidigung most often arise (in the common hallways of apartment buildings, see id.), when they most often arise (in the month of August when warmer weather is conducive to more frequent social interaction, see id. at 16; and between the hours of 4 P.M. and 8 P.M. when the pent-up frustrations of the day are finally released, see id. at 17); sce also the data and discussion in Bierbrauer et al., supra note 58, at 65-78. Somewhat drier, but also rich in data, is Rüdiger KoewiUs, Die ReChtSWIRKLIChKeIT Der PRIVATKLAGE 64-95 (1974), which portrays modern Beleidigung as a result of modernization, urbanization, tenements, close quarters, and auto traffic.

72. SCHÖNKE-SCHRÖDER, supra note 54, §185, at 1391 (noting also the constitutional limitations of GG Art. 5 (F.R.G.)).

73. See Landgericht [LG] Frankfurt/M. [Trial Court of Frankfurt am Main], NJW. 27 (1974), 2244 (F.R.G.), reprinted in part in HOHNEL, supra note 45, at 8-9. In this 1974 case, a local chairman of the Social Democratic Party was prosecuted privately for declaring that a Christian Democratic chairman had engaged in a "shameless lie" (unverschämte Liige). Sec also the cases of political insult described in Kübler, supra note 49 , at 547 \& $n .95$.

74. See Kübler, supra note 49. For a successful recent prosecution, see OLG Zwcibrìcken [Court of Appeals for Selected Matters in Zweibrücken], June 9. 1996, JURIS ref. no. KORE470219600, which reports the conviction of an accused who had called local political leaders "[d]ie Wahnsinnigen vom 6. Stock des Rathauses," "Rechtsamts-Schreckschrauben," and "lächerliche, bisweilen fette, ranzige, unhöfliche und einfach nur noch widerwärtig uniformierte Befehlsempfänger einer Kommunalpolitik" ["the lunatics on the sixth floor of town hall," "official battle axes," and "ridiculous, sometimes greasy, rancid, rude, and just plain repellent uniformed toadies of town politics"].

75. For a constitutional critique that draws heavily on the American experience, see Friedrich Kübler, Ehrenschutz, Seibstbestimmung, und Demokratie, 52 NJW 1281 (1999). 
Germans see the world of politics differently from the way ordinary Americans do. Americans may have a similarly baffled reaction to the doctrine of Schmähkritik, "contemptuous criticism," which allows the prosecution of the authors of insulting book, theater, movie, and art reviews. $^{76}$

The German law (and culture) of insult also includes intriguing subareas. Especially interesting to many Americans will be the law of "sexual insult." " Sexual behavior can also, from the German point of view, involve the showing of "lack of respect, or disrespect." So it is that the law of insult historically underpinned, for example, the German defense of justification for a cuckolded husband who murdered his wife's adulterous lover, at least if the adulterous pair had been caught in the act. ${ }^{78}$ The law of sexual insult has also historically given an action to cuckolded husbands against their rivals. ${ }^{79}$ There is more, too. When men come on to women, they may, according to German lawyers, do so in a criminally insulting way.

For, indeed, the German law of insult requires that men show "respect" to women. This is a doctrine that may sound appealing to some Americans, especially to feminists who have tried to ground the law of sexual harassment in some norm of respect. It is all the more important, then, to observe that, in practice, the law of sexual insult has taken forms that are likely to seem unsavory to Americans. "Respect" is a more ambiguous, complex, and socially conditioned concept than most of our American legal literature admits, and respect for women, in German law, is understood in a way that does little to prevent even very gross male behavior. This is true, first and foremost, because showing a woman respect, as German lawyers have historically viewed the law of sexual insult, can include treating her as attractive or desirable. This means that many unwanted sexual advances have presented no problem under the law of sexual insult: To come on to a woman, as German courts and scholars have repeatedly observed, could represent nothing other than a show of a

76. For Schmähkritik under the jurisprudence of $\S 193$ StGB, sce, for example, the discussion in SCHÖNKE-SCHRÖDER, supra note 54, \$193, at 1414-15. This is a doctrine against which. again, constitutional doubts have been raised. See Kübler, supra note 75 , at 1286. For the contrasting American attitude, see POST, supra note 7, at 111, which casually assumes that critics have the right to speak disrespectfully of a novel.

77. See infra note 80 and accompanying text.

78. A husband whose wife had had sexual relations with another man had-and indeed theoretically still does have-a cause of action for insult against his rival. This has led. however. to objections from scholars, who argue that the will of the legislator to exempt adultery from legal sanction should not be frustrated by prosecutors under the insult paragraph. See DOERING, supra note 45, at 109 n.1; HANS JOACHIM HIRSCH, EHRE UND BELEIDIGUNG 66-67 (1967).

For a nice pair of cases in which a wife's lover was convicted of insult and a husband's lover was acquitted, see HOHNEL, supra note 45, at 13-14.

79. Though this is probably not tue any longer. See SCHONKE-SCHRODER, supra note 54, $\S 185$, at 1388 . 
distinct kind of respect, an appreciation for her desirability. The sorts of advances that have been sanctionable under the law of sexual insult are those that implicitly treated their target as a Dirne - as a "wench," or as a woman of easy virtue.$^{80}$ Only advances that placed a woman on the lowest level of social respect, the level that included women who were of easy virtue, constituted sexual insults-and then, of course, only if they were directed at women who did not fit that bill. This corresponds, clearly enough, to a very traditional concept of respect, linked to a very traditional concept of sexual honor, much like the concept of the right of the cuckolded husband in this body of law. A recent newspaper report gives the flavor of the resulting respect-oriented law of sexual relations. In this case, a woman complainant brought a Privatklage, a private criminal prosecution of the kind permitted in the law of insult:

Bosom Groping Judicially Recognized as "Personal Need": Public Prosecutor Discontinues Investigative Proceeding Despite Evidence. The Groping of One's Bosom Is Not "Intended" as Insult.

Since mid-September, Frankfurt resident Vera Steiner has had every reason to doubt her chosen profession. "You know, you study law yourself, and then this kind of crap happens to you."

The "crap" that the future attorney would not have believed possible is being served up by the Frankfurt Office of the Public Prosecutor (Amtsanwaltschaft). It is a decision that cancels an investigative proceeding for insult initiated by Steiner-one of the few proceedings for sexual harassment that actually stood a good chance of leading to a conviction. The good chance of conviction was due to the fact that Steiner could produce ironclad evidence: A man groped her bosom-not in private, not in some dark corner, but rather in broad daylight, in public, in the middle of the crowded Frankfurt shopping street Senckenberganlage. The man was walking with his children, and Vera Steiner was with a friend, and the breast groping was accomplished as they passed one another in the street. Steiner protested loudly, the man let go and rushed to his car with his children. Vera Steiner had the presence of mind to note his license plate number. The law student later reflected that she wasn't even wearing a miniskirt at the time, but rather a long skirt with a jacket. It was a vain attempt to lend even a questionable logic to the sudden attack. Such details did not concern the Frankfurt Office of the Public Prosecutor. They came to the decision that "according to the current articulation of the law by the Federal Supreme Court, a sexual insult of the complainant" did not occur. The Public Prosecutor (Amtsanwalt) instructed the law student that the Federal Supreme Court decided "that Paragraph

80. See generally id.; BGH [Federal Supreme Court], NJW, 39 (1986), 2442 (F.R.G.). 
185 Insult (Penal Code) is met only when the perpetrator, through sexual conduct, expresses [the belief] that the victim has some personal deficiency that diminishes the victim's dignity or honor." "The conduct of the accused must exhibit an intentional, demeaning valuation of the victim." The Public Prosecutor did not recognize any such demeaning valuation, and therefore he informed Vera Steiner that "the required motivation on the part of the accused is not provable in the instant case. There are not sufficient indicia present to indicate that his conduct was intended to injure the complainant's right to respect in society." The Public Prosecutor comes to the compassionate conclusion: "It is possible, rather, that he was trying to satisfy some personal need, without demeaning the witness." How a man can do the first without doing the second remains the secret of the Public Prosecutor. But Berlin attorney Alexandra Goy rejects the Public Prosecutor's apologetic assertion that he is in harmony with the "highest judicial articulation of the law, which is subject to criticism but ultimately binding." ....

Law student Steiner received a little lesson in practical private law. She still has the option of filing a [civil] complaint against the bosom-groper to demand damages for pain and suffering. But then he would find out where she lives. And, as it was carefully explained to her, you never know how people like him are likely to react. $^{81}$

This case is typical of a longstanding jurisprudence on sexual insult, much of which will seem astounding to American readers. Instances of spectacularly aggressive behavior on the part of males have been held not to constitute insulting behavior. ${ }^{82}$ It is also a case that reflects something that

81. Dieter Rulff, Busengrapschen als "persönliches Bedarfnis" richterlich anerkanns, BERLINER TAGESZEITUNG, Oct. 11, 1995, at 5 (translated by Gabrielle Friedman). While the exact procedural details of this case are not clear from the newspaper repon, presumably the Public Prosecutor assumed control of the case because it was potentially linked to a case of sexual assault. On this, see Geppert, supra note 49, at 531. Readers may indeed wonder whether the assailant here was not guilty of some offense of sexual assault. This mises questions that I leave for discussion elsewhere. But it should be noted that such sexual assaults have generally been treated mildly in recent European law, and paricularly in German law. See, e.g., SUSANNE BAER, WÜRDE ODER GLEICHHEIT: ZUR ANGEMESSENE GRUNDRECHTLICHEN KONZEPTION VON RECHT GEGEN DISKRIMINIERUNG AM BEISPIEI SEXUELLE BELÄSTIGUNG AM ARBETTSPLATZ IN DER BUNDESREPUBLIK DEUTSCHLAND UND DER USA 127, 130-31 (1995). The assailant in this case would likely have faced a small fine, if any punishment at all. Here we observe a phenomenon of importance for European sexual harassment law: The general tendency to decriminalize "morals" offenses and to reduce punishment has tended, in the last decades, to defang the law of sexual assault in Europe.

82. See, for example, the "Old Age Home" case, in which the proprietor of an old age home, after attempting to rape a sleeping employee, retreated in the face of the employee's resistance. At trial, the proprietor was found to have engaged in a "permissible form of cournship." OLG Zweibricken [Court of Appeals for Selected Matters in Zweibrucken], NJW, 39 (1986), 2960 (F.R.G.), reprinted in BAER, supra note 81, at 137. For a selection of decisions, see KLAUS BERTEL SMANN ET AL., HANDBUCH ZUR FRAUENERWERBSTÄTIGKETT 1993 § (1996). For 
deserves some emphasis: The law of insult aims to guarantee that no individual intentionally shows demeaning disrespect for another individual. That is to say, it focuses on what I earlier called the outward show of respect. What it does not do is focus on the general climate of dignity for groups that have traditionally been regarded as socially inferior. What the law of insult does not aim to do is establish norms that will protect traditionally inferior groups, such as women, from treatment that is likely to reinforce their sense of vulnerability, inferiority, or exclusion. It asks only whether individual women have been the targets of an open and unambiguous display of personal contempt-of, in the words of our commentary, "the expression of the offender's own lack of respect for the victim." ${ }^{83}$ The question they do not ask is whether the acts or words of an individual have endangered the general climate of dignity for (in this case) women.

The same is true, finally, in another subarea of the law of insult: the law of collective insult. This is the aspect of the German law of insult that forms the original basis of the German regulation of hate speech-though since 1960 it has also been supplemented by further law on "incitement of hatred," to which I will return shortly. ${ }^{84}$ The law of collective insult has some similar limits that have not always been acknowledged. It is indeed the case that Jews are extensively shielded from "disrespectful" insults under current German law. Such insults infamously include efforts to deny the truth of the Holocaust. ${ }^{85}$ The German commitment to protecting Jewish sensibilities is in this regard remarkably far-reaching. ${ }^{86}$ It is important to recognize, though, that the broader German commitment to respectful treatment is somewhat less far-reaching. Members of other groupsnotably Turks, the focus of disproportionate hostility in the German public sphere today-are certainly protected against insults, like all Germans. But

German case law mitigating sexual harassment that actually approached sexual assault on the grounds that the perpetrator was experiencing "sexual frustration," see BAER, supra note 8I, at $67,132$.

83. See supra note 63 and accompanying text.

84. See infra notes $186-187$ and accompanying text.

85. See, e.g., BVerfG [Federal Constitutional Court], NJW, 47 (1994), 1779 (1780) (F.R.G.) (holding, in the context of a right-wing meeting featuring revisionist historian David Irving. that the statement that "there was no persecution of Jews during the Third Reich" is not constitutionally protected speech because it is a provably false statement, and that the denial of such persecution is an insult to all Jews presently living in Germany).

86. Even here, however, German juristic sensibilities can differ weirdly from American ones. The definition of "Jew" for purposes of this body of law is still drawn from Nazi doctrine. See BGH [Federal Supreme Court], NJW, 33 (1980), 45, (45-48) (F.R.G.) (holding that the plaintiff had standing to pursue an insult complaint based on a poster claiming that the "murder of six million Jews" was a "Zionist swindle," because under the Nuremberg Race Laws of 1935. the plaintiff would have been classified as a "Jewish Mongrel of the second degree" [Mischling zweiten Grades], and therefore subject to Nazi persecution). This would presumably not prove ideologically possible in the world of American law. Cf. Stein, supra note 16, at 866 (noting the strangeness of this doctrine in American eyes). 
allegations of anti-Turkish insults, unlike allegations of anti-Jewish ones, are subjected to the usual juristic analysis, that is, to a factual inquiry as to whether they display an intentional "lack of respect or disrespect" on the part of the person delivering the insult. This is why bar-owners who post signs excluding Turks may not have committed an "insult" under German law: The operative question, under the law of insult, is again whether the individual bar-owner has indulged in an open and unambiguous display of "his own lack of respect for the victim." As in the case of the bosomgroper, German jurists ask whether there has been an outward show of individual disrespect, not whether the larger climate of equal dignity has been endangered. In the case of Turks as in the case of women, the aim of the law of insult is to safeguard individuals against intentional displays of disrespect, not to eliminate the larger patterns of social exclusiveness that affirm group inferiority. Indeed, even the term "collective insult" is misleading: In German doctrinal treatment of groups such as Turks, there has long been a tendency to resist the idea that most groups as such can normally be cognizably insulted. The strong tendency has been to hold that, if there is any insult at all, each individual member of the group is insulted on account of his or her membership. Indeed, a standard commentary holds, there are so many Turks in Germany that it is impossible that any single insult could be understood as touching each one of them. ${ }^{87}$ In this doctrinal

87. See SCHÖNKE-SCHRODER, supra note $54, \S 185$, at $1382-83$ (contrasting the treatment of Jews with that of Turks):

Ungeachtet ihrer Zahl wird von der Rspr. die Kollektivbeleidigungsfuhigkeit der in Deutschland lebenden Juden bejaht ... was nur damit zu begrilinden ist, daB sie wegen des in der Geschichte einmaligen, "ihnen vom Nazionalsozialismus auferlegten Schicksals in der Allgemeinheit als eine eng umgrenzte Gruppe crscheinen." .. Für andere, zahlenmäßig nicht mehr ohne weiteres überschaubare... "Teile der Bevölkerung" (§130) gilt dies jedoch nichı... [wic] z.B.... für pauschale Beschimpfungen der bei uns lebenden Türken ....

Case law has accepted the capacity of the Jews now living in Germany to suffer a collective insult regardless of their numbers... which can only be justified by reference to the fact that they "appear as a narrowly limited group within the general population on account of the [historically unique] fate to which they were subjected by the Nazis." . . For other "segments of the population" ( $\$ 130)$ who are, without more, numerically not easy to view as a single whole. this is not the case, however ... a for example ... with regard to abusive language aimed at Turks as a whole .....

For the rise of this as dominant postwar doctrine apar from the (always special) case of Jews, see NikOlas ANDOULAKIS, DiE SAMMELbEleidigung 28-33 (1970). For its role in the " Soldiers are Murderers" case, see Peter J. Tettinger, Das Recht der persönlichen Elure in der Wertordnung des Grundgesetzes, 37 JURISTISCHE SCHULUNG 769-76 (1997). For its Nazi-era prehistory, sce infra notes 147-148 and accompanying text. This doctrine also is taken to mean that women, since they constitute too large and ill-defined a collectivity, are not a cognizable group. See BAER, supra note 81 . The sorts of groups that are generally regarded as cognizable under German law will indeed strike most Americans as belonging much more to the class of the sociopolitical in-groups than to the class of the excluded: They are such "groups" as the German judiciary, the armed forces, doctors, patent attomeys, the police, executive officers of large banks. and the like. See SCHÖNKE-SCHRÖDER, supra note $54, \S 185$, at 1383. The Jews are quite exceptional as a protected out-group. 
tradition, too, we see that the idea of the individual show of respect still lies at the heart of German insult law.

All this does not mean that a Turkish complainant can never prevail. ${ }^{88}$ What it means is that there is no per se prohibition on hate speech directed against Turks or other non-Jews in Germany, no matter how much social hostility they may face. German collective-insult law thus does not do what some American advocates of hate-speech law would like to see done: It does not establish structural ground rules for respectful interracial relations that will operate regardless of the (ever-elusive) subjective intent of the persons involved. It does not aim to guarantee an atmosphere of dignity. What it does do is to make Turks, and members of other minorities, full participants in a cultural system that gives every individual the right to complain to authorities after being "dissed," or after being shown disrespect. It gives them as individual members of a group the same rather mystifying right to honor that all Germans have.

Indeed, the German law of insult will generally be fraught with mystery for the American reader. This is a body of law that shows, in many of its doctrines, a numbness to free-speech concerns that will startle any American. Its law of sexual insult is rooted in what will strike many Americans as comically antiquated notions of sexual honor and desirability. As for its law of collective insult, in its emphasis on Jews it has an ad hoc quality-though to be sure, one that is understandable in historical perspective. All of this will inevitably lead Americans to wonder whether such a body of law can survive in a modern democratic society. Nevertheless, it survives. ${ }^{89}$

88. One interesting 1978 case involved the following facts. A German woman hit a Turkish woman on the head with a beer glass and called her a "witch" and a "whore." The Turkish woman's subsequent suit was at first dismissed as trivial. On appeal, however, the suit was reinstated on the grounds that being called a "witch" (Hexe) is a "grave injury to the reputation of a Turkish guest worker." The appeals court directed that a specialist in Turkish popular culture be called to testify. See LG Mannheim [Trial Court of Mannheim], NJW, 32 (1979), 504 (F.R.G.), cited in HOHNEL, supra note 45, at 6-7.

89. There are certainly respects in which the law of insult has come under attack. The law of sexual insult in particular is in a state of decline. Unsurprisingly, some German feminists have not been enthusiasts for this law of sexual insult, and they attacked it during the 1980s. See, e.g. Brigitte Sick, Die Rechtsprechung zur Sexualbeleidigung, 46 JZ 330, 330-35 (1991) (arguing that the outmoded notions of sexual purity underlying the doctrine of sexual insult allow a great many instances of sexual violence against women to go unpunished). Well before feminists began to raise their objections, though, other German jurists had begun to do the same, although on other grounds. In the mid-1960s, there was an influential campaign against the law of sexual insult. This had, clearly enough, something to do with the revolution in sexual mores of the time. But it took the form of juristic objections to the practice of using the law of sexual insult as a "residual category," prosecuting sexual offenses that were not otherwise punishable as insults. See, e.g., HIRSCH, supra note 78, at 61-62; Wulf Heinrich Droste, Beleidigung als Sittlichkeitsdelikt: Eine Untersuchung der Rechtsprechung zur Anwendung des \& 185 StGB auf unsittliche Handlungen und der dabei von ihr angewandten Methode (1972) (unpublished doctoral dissertation. ChristianAlbrechts-Universität (Kiel)) (on file with The Yale Law Journal). For the small number of sexual-insult cases under this doctrine, see DOERING, supra note 45 , at 46 . Under fire from both 


\section{THE ROOTS OF THE LAW OF INSULT IN PREMODERN SOCIAL HIERARCHY}

Strange and at times comical as the German law of insult is, it does have an appeal that Americans may feel, and may even feel strongly. "Honor" and "respect" are values that really do pervade German law. The pervasiveness of these values has provided the basis for a law of hate speech; and even if the law of sexual insult is not terribly attractive, it may be that, in the future, Germans will produce a respect-based law of sexual harassment that many Americans would like to imitate. ${ }^{90}$ Could we have a law like this in the United States?

feminists and specialists in criminal law, the law of sexual insult had fallen into decline, or at least partial eclipse, by the mid-1980s. See BGH [Federal Supreme Cour]. NJW, 47 (1989), 3028 (3029) (F.R.G.); BGH [Federal Supreme Court], Neue Zeitschrift ful Strafrecht [NStZ], 13 (1993), 182 (F.R.G.); Walter Kiehl, Das Ende der "kleinen Sexualdelikse"?. 42 NJW 3003 (1989) (discussing the restrictiveness of current law). Moreover, its role-to the extent it has one-is perhaps being taken over by new doctrines on sexual harassment, to which I will turn brienly below.

If sexual insult is in trouble, though, the rest of the body of law still seems likely to survive. There are certainly voices in Germany that object to the law of insult, at least as it exists. Some commentators have argued that the criminal law on insult is so vague as to be unconstitutional. See STARK, supra note 14, at 139 an.30-31. There are also German jurists who have rebelled against the law of insult on free-speech grounds-especially those jurists who have spent time in the United States. One may cite Kübler for this proposition, although his principal concern is the law of defamation. See Kuibler, supra note 49, at 541-42 (discussing American law and its influence on Germany). Professor Kubler is a member of the faculty at Frankfurt am Main who, in the year of the publication of that article, became a faculty member at the University of Pennsylvania as well. For what are perhaps more indigenously German views, sce, for example, MACKEPRANG, supra note 15. The influence of another such scholar oriented toward America. Justice Dieter Grimm, a frequent visitor to the United States, has led to a major current controversy. But that controversy has not eliminated the law of insult; in fact, it can be said to demonstrate how deep the general commitment to the law of insult goes, both in the legal profession and in the popular mind. The controversy in question surrounds the so-called "Soldiers are Murderers" case. During the Gulf War, a left-leaning social-studies teacher in Bavaria put a bumper sticker on his car reading "Soldiers are Murderers." He was successfully prosecuted for insult-for insulting, that is, all German soldiers-in a decision affirmed at every level of the ordinary court system. In a kind of revolution from above, however, the German Constitutional Court, led by Justice Grimm, overtumed the conviction on grounds that must seem clearly persuasive to most American readers: The prosecution of the teacher, the court held. violated norms of free speech. If Americans would tend to see the justice in that decision. Germans very much did not. The storm in the popular press was extraordinary, as was the outpouring of scholarly literature, which bitterly condemned the court's decision. An abbreviated translation of the decision appears in DONALD KOMMERS, THE CONSTITUTIONAL JURISPRUDENCE OF THE FEDERAL REPUBLIC OF GERMANY 388-95 (2d ed. 1997). For a description of the "Soldiers are Murderers" case, of Justice Grimm's role in it, and a (distinctly conservative but nevertheless revealing) account of the resulting storm, see Tettinger, supra note 87, at 776 . For reactions, see id. at 772-75. To very many Germans, both professional lawyers and others, it seemed an outrage that the court should have stood in the way of prosecuting the "insult" of the "Soldiers are Murderers" bumper sticker. For a much earlier case also involving the phrase Soldaten sind Mörder, see RG [Imperial Court], JW, 62 (1933), 972 (F.R.G.). The law of insult thus seems likely to continue in Germany, at least for a while.

90. See infra notes $357-359$ and accompanying text. 
In this Part, I suggest that we could not have such a law. Indeed, I am going to raise some initial doubts about whether we would want such a law, even if we could have it. The cultural and historical origins of the law of insult, I argue, lie in traditions of social hierarchy that we lack, and indeed, aggressively reject. Principally, those hierarchical traditions are aristocratic ones. To a certain extent, they are Nazi traditions of a complex kind. They are, in any case, traditions that have had very little life in the United States. The broad egalitarian honor culture that we see in Germany today is the product of many centuries of harsh inequality; to understand the making of the German law of insult, we must dig into what, to Americans, is likely to seem a dark past of social hierarchy.

Some readers may already have guessed that the law of insult, as it exists today, has aristocratic sources. Germans involved in insult litigation display a kind of touchy sense of their own "honor" that is very much reminiscent of the aristocratic duelists' world of the eighteenth and nineteenth centuries.

And indeed, the law of insult, as it exists in modern-day Germany, is a kind of living fossil, preserving features that date to a premodern era in which German law was concerned with maintaining elaborate norms of social hierarchy and deference. The law of insult, which today applies to all Germans, once upon a time generally applied only to certain high-status ones. Thus the substance of the contemporary law of insult does indeed grow, strikingly enough, largely out of old dueling practices; legally cognizable insults that we see today generally began as insults offered to dueling aristocrats. More broadly, the doctrines of the contemporary law of insult, with their focus on showing respect, trace back to a time when the law was greatly concerned with deference-with compelling low-status persons to show respect to high-status ones. These roots of the law of insult in premodern social hierarchy go almost entirely unmentioned in the standard German literature today, ${ }^{91}$ but they are of deep importance for

91. Binding was still conscious of dueling as the prime context for the formation of the law of Beleidigung. See KARL BINDING, DIE EHRE IM RECHTSSINN UND IHRE VERLETZBARKEIT 37-38 (Leipzig, Edelman 1890). So, for that matter, was Max Weber. See MAX WEBER. WIRTSCHAFT UND GESELlSCHAFT 185, 372 (Studienausgabe 5th ed. 1972) ("[D]er deutsche Richter [untersucht] in Beleidigungsprozessen die 'KommentmäBigkeit' der Ablehnung einer Forderung zum Zweikampf, obwohl doch dieser gesetzlich verboten ist..."). For the concept of Kommentmäßigkeit, the test of whether members of student societies understand "comment," or "how" to behave, sec UTE FREVERT, EHRENMÁNNER: DAS DUELL IN DER BÜRGIRLICHEN GESELLSCHAFT 136 (1991). Among current commentators, Friedrich Kuibler notes that the section on Beleidigung was followed by the section on dueling in the Criminal Code until the latter was abolished. See Kübler, supra note 49, at 544. Jörg Tenckhoff also has a few words on the subject. See JÖRG TENCKHOFF, DIE BEDEUTUNG DES EHRBEGRIFFS FÜR DIE SYSTEMATIK DER BELEIDIGUNGSTATBESTÄNDE 20 (1974) (discussing the roots of insult in the law of ducling). Particularly insightful is KoEwIUS, supra note 71 , at 28-32, which discusses how dueling and the culture of honor reduced the reliance of the upper classes on the judicial system. For the most part, though, the connection has been forgotten. The historian Ute Frevert, too, in her superb book on 
understanding what it is that sets this striking German legal culture of insult apart from anything we can find in the United States. The key to interpreting German insult law as it exists today is to understand how it made the transition from a world of social hierarchy to a world of formal equality-from a world of restricted aristocratic honor to a world of general human dignity.

As we follow the modern-day law of insult back to its beginnings, 150 or 200 years ago, we first discover its deep connection with dueling. Standard doctrinal accounts of German legal history occasionally tell us that the law of insult is part of Germany's civil-law tradition, the modern German version of the ancient Roman law of insult, the actio injuriarum.2 And indeed, like most of German law, the modern law of insult does have some doctrinal roots in ancient Roman law. Yet mere doctrinal history obscures much of what matters most. ${ }^{93}$ It is really the history not of Roman doctrine, but of indigenous German social pressures, that formed the law of insult we see today.

As Roman law spread into Germany from the late Middle Ages on, it spread to a society in which insults played a part not really contemplated by the Roman texts, and its character changed fundamentally as a result. The suppression of aristocratic dueling was a major preoccupation of early modern monarchies and princedoms, and many German localities had statutes that aimed to induce "insulted" aristocrats to come into court rather than duel..$^{94}$ Concerned as they were with duelists, these statutes contemplated very different sorts of insult from the insults treated in Roman law. The ancient Roman law of insult was the product of a raucous Mediterranean society in which persons of immense social prestige walked the city streets accompanied by retinues of followers and slaves. It was primarily concerned with safeguarding the sexual honor of high-status

19th-century dueling, writes, "Ein solcher emphatisch aufgeladener Ehrbegriff, wie er milinnlichen Angehörigen sozialer Oberschichten noch Ende des 19. Jahthunderts eigen war, scheint in heutigen Lebensverhältnissen und Selbstbildern keinen Platz mehr zu haben." "IS]uch an emphatically charged concept of honor, which still came naturally to male members of the upper social strata at the end of the 19th century, seems to have no place any longer in the human relations and self-images of today." FREVERT, supra, at 11 (citing the American sociologist Peter Berger). This is true of the United States, but an undercharacterization of a more complex German reality.

92. See, e.g., Droste, supra note 89. at 2-8. The history of the supposedly "Roman" law of insult is an object lesson, indeed, in how incompletely the theory of "transplants," proposed by Alan Watson as the great motor of world legal development, explains the detailed workings of the law. The spread of Roman law into Germany. from the late Middle Ages onward, is the most famous instance of "transplantation" in Westem legal history. Yet indigenous social pressures deeply transformed the Roman law of insult.

93. For a more nuanced description of the sources of the German law, see KoEwius, supra note 71 , at 33-39.

94. For the consistent connection of these older statutes with the law of insult, sec THEODOR

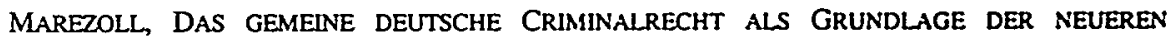
DEUTSCHEN STRAFGESETZGEBUNGEN 426 n.l (Leipzig. Barth $2 \mathrm{~d}$ ed. 1847). 
women; ${ }^{95}$ with penalizing certain kinds of carnivalesque popular rituals $;{ }^{96}$ and, to a certain extent, with guaranteeing deference for high-status persons. ${ }^{97}$ It often spoke of insults that took the form of a severe physical thrashing. ${ }^{98}$ None of the Roman texts treated anything quite like the problem of affairs of honor between early modern duelists, in which statusequals, sensitive to a fault, showed themselves ready to die over a slight, or even a mere touch-over even minor failures to make the outward show of respect. ${ }^{99}$ Nor, importantly, did the Roman texts imagine remedies like those envisaged in early modern dueling culture. Ancient Roman law awarded the victim of an insult money damages. ${ }^{100}$ By contrast, among early modern aristocrats, especially of the seventeenth and eighteenth centuries, ${ }^{101}$ it was generally regarded as a matter of severe dishonor to accept money damages in "satisfaction" of an insult. Insults were to be avenged through violence, not through litigation, and least of all through money payment. ${ }^{102}$ In consequence, early modern German statutes provided for remedies with an orientation toward the restoration of honor-in particular, forced apologies and retractions. ${ }^{103}$

95. See RÖMISCHES RECHT 369-70 (Heinrich Honsell et al. eds., 4th ed. 1987).

96. On the convicium, see $i d$. at 369.

97. This phenomenon is particularly prominent in the Institutes of Justinian. See J. INST. 4.4.7-.9.

98. So I interpret the Roman texts-for example, the classic statement of Gaius, adopted also in the Institutes of Justinian: "Iniuria autem committitur non solum cum quis pugno puta aut fuste percussus vel etiam verberatus erit, sed etiam si cui convicium factum fucrit..." "Insult is committed not only by striking a man with the fist or with a stick or by flogging him, but also by raising a clamor against him ...." G. INST. 3.220. I have lightly altered Zulueta's translation. $C f$. J. INST. 4.4.1. (surveying the Roman law of insult). I take these passages, along with the constant references to "pulsatio" in the Digest, see, e.g., DIG. 47.10.1.2 (Ulpian, Ad Edictum 56) (pulsatur); DIG. 47.10.9.pr. (Ulpian, Ad Edictum 57) (pulsatio), to presuppose a world in which jurists did not have in mind anything like the single insulting slap of the world of dueling when they spoke of physical assaults; they spoke of a world in which more extensive beatings took place.

99. To be sure, there were some aspects of German society to which the Roman law of insult applied more comfortably. See, for a wonderful example, [PATRONUS NUPTURIENTIUM]. DE INJURIIS QUAE HAUD RARO NOVIS NUPTIS ... INFERRI SOLENT (Quedlinburg \& Aschersleben, Strunz 1699), a pamphlet concerned with extending the action of insult to protect newlywed women against a variety of popular charivari-like rituals questioning their virginity. This fit more comfortably than much of the dueling problematic under the Roman concept of convicium. My argument is not that there was nothing in German society to which the Roman law could be applied, but that the dueling and deference problematics played a disproportionate role in shaping the German law of insult.

100. See RöMISCHES RECHT, supra note 95 , at 370 . When early modern lawyers tried to argue against this practice from Roman texts, they cited DIG. 9.2.13 (Ulpian, Ad Edictum 18) ("dominus membrorum suorum nemo videtur") from which was drawn the adage. "Liber homo non recipit aestimationem."

101. For the growth of dueling in this period, see PREVERT, supra note 91, at 28-29.

102. Frevert also discusses the continuing 19th-century attitude. See id. at 13.

103. See the survey of early modern jurisprudence in 2 CARL AUguST TITTMANN, HANDBUCH DER STRAFRECHTSWISSENSCHAFT UND DER DEUTSCHEN STRAFGESETZKUNDE 28589 (Halle, Hemmerde \& Schwetschke 2d ed. 1822-1824). Legislators could, of course, be of two minds, as Frevert's citation of Frederick II shows: On the one hand, Frederick insisted, in 1770. 
Such early modern dueling norms mattered immensely for the formation of modern insult law, because for premodern jurists, the law of insult was central to the campaign for eliminating the evil of dueling. ${ }^{104}$ If duelists were to be dissuaded from acts of violence, they had to be offered a forum in which the insults they had received could be punished. This meant that the law of insult had to be formulated in such a way that it could provide a courtroom alternative to the duel. This was true not only in the early modern period, but also in the nineteenth century, the period when the law of insult took its modern form. As the modern law of insult began to develop in the early nineteenth century, it remained closely linked to the duel. "If we wish to prevent the sad evil of the duel," wrote a prominent jurist in 1819, "we must be concemed with making effective and welltailored statutes against insults." 105 Unavoidably, in this atmosphere, jurists tended to define legal insults in the way that duelists understood them. Thus when one important jurist, writing in 1826, hunted for examples of true insults, he naturally picked (despite his fondness for Roman law) insults that belonged to the status-conscious world of the dueling aristocracy: Insults, he said, had to be acts " with a very specific bearing on honor, such as spitting on a person, or slapping him." 106 These uncharming gestures did

that Privatbeleidigungen were a matter for the law; on the other, he acknowledged the necessity of dueling. See FREVERT, supra note 91, at 34. The establishment of special "courts of honor" was also a recurring theme. See id. at 54 . Frevert describes the penetration of the ducling problem into the Ehrengerichte (honor courts) of the professional associations of doctors and lawyers. See id. al 171-72. For a survey of early modern practice with regard to retractions, apologies, and the like, see 2 TITTMANN, supra, at 285-89.

104. See FREVERT. supra note 91, at 54. Jurists pointed “immer wieder auf die Notwendigkeit, das Injurienstrafrecht... zu verbessem" in order to climinate ducls. For examples, see C.J.A. Mittermaier, Injurien, in 5 RECHTSLEXIKON FOR JURISTEN ALLER TEUTSCHEN STAATEN 869, 870 (Julius Weiske ed., Hamburg. Wigant 1844). For the larger early modern perspective on anti-dueling measures, see FrANÇOIS BILLACOIS. THE DUEL: ITS RISE AND FALL IN EARLY MODERN FRANCE 21-48 (Trista Selous unas., Yale Univ. Press 1990) (1986).

105. C.J.A. Mittermaier, Bemerkungen über Duellgesetze und den Zusammenhang derselben mit den Gesetzen über Ehrenverletzungen, 3 NEUES ARCHIV DES CRIMINALRECHTS 436, 446 (1819) ("Will man nun dem traurigen Uebel der Duelle vorbeugen, so muB man ... fir sichere zweckmäBige Gesetze gegen Beleidigungen Sorge uragen ....").

106. 2 CARL GEORG WÄCHTER, LEHRBUCH DES ROMISCH-TEUTSCHEN STRAFRECHTS 89 (Stuttgart, Metzler 1826). I do not mean to minimize the extent to which early-19th-century jurists wished to reframe German law in Roman terms. On the contrary, I have argued elsewhere at great length that exactly that was the case. See JAMES WHITMAN. THE LEGACY OF ROMAN LAW IN THE GERMAN ROMANTIC ERA (1990). For a fine example of an early-19th-century romanizing jurist. SEe THEODOR MAREZOLL, UEBER DIE BURGERLICHE EHRE, IHRE GÄNZLICHE ENTZIEHUNG UND THEILWEISE SCHMÄLERUNG 326 (Giessen, Meyer 1824), which makes a romanizing attempt to dismiss hierarchical honor: "Manche Rechte gewisser bevorzugter Stande sind entweder ganz aufgehoben, oder, ohne Unterschied des Standes, allen Staatsbürgem gleichmaßig crtheilt worden. Dadurch hat der Gegensatz der allgemeinen und besonderen bürgerlichen Ehre sehr viel von seiner früheren Bedeutung und Wichtigkeit verloren." "Many rights of certain favored socialstatus groups have been either completely abolished, or accorded to all citizens equally without regard to status. In consequence, the contrast between general and particular social honor has lost very much of its earlier significance and importance." 
not feature prominently in the Roman texts, ${ }^{107}$ but they were common in the world of dueling. ${ }^{108}$

If the culture of dueling affected the idea of what counted as a wounding insult, it also affected, inevitably, the idea of what could salve the wound. The idea that it was dishonorable to take money compensation hung on and was indeed endorsed by nearly every major jurist over the course of the nineteenth century, often in tones that betrayed a kind of aristocratic contempt for those who could not comprehend the value of honor. ${ }^{109}$ While there were some brilliant nineteenth-century German jurists who thought honor should be safeguarded in a new civil law of the protection of personality, ${ }^{110}$ their efforts were essentially doomed by the deep-rooted hostility to money damages. That hostility culminated, famously, in the making of the German Civil Code of 1900, whose draftsmen refused to make any broad provision for money damages to satisfy injuries to "nonmaterial" interests. The draftsmen defended this refusal in terms that showed how deeply lodged in German hierarchical social structure the law remained:

[I]t [would be] repugnant to the dominant opinion among the population to place nonmaterial values on the same level as property interests[,] and to make good with money interferes with nonmaterial interests. The Code ... should not ignore this view, especially prevalent among the better circles of society. Only the

This was very honorable wishful thinking. I do not by any means wish to argue that such wishful thinking did not exist, only that the fact of hierarchical social relations, and of the duel, inevitably penetrated most legal analysis regardless of this sort of romanizing.

107. Spitting does not, as far as I can determine, figure in the Roman texts at all. A striking of the face was, it is true, regarded as an aggravated insult in Roman law. See DiG. 47.10.7.8 (Ulpian, Ad Edictum 55) (os alicui percussum). Nevertheless, the emphasis in the Roman texts is on the pulsatio, the thrashing; the Roman jurists did not focus on the slap in the way the authors on dueling did.

108. The slap is the classic dueling insult of the 19th century. See, e.g., LE CTE. DE Chatauvillard, ESSAI SUR LE DUEl 94 (Paris, Chez Bohaire 1836) (stating that a slap in the face is the insult "la plus grave de toutes") ("the most serious"). Spitting, for Chatauvillard, is presumably one of those "offenses graves qui entraînent avec elles la nécessité d'une représaille suite," "serious offenses that require an immediate reprisal," rather than a duel. $l d$. at $\mid 1$. Is it possible that slapping played the large role it did in the dueling culture because of the cultural importance of Christ's injunction to turn the other cheek? See, e.g., Matthew 5:11, 5:39.

The history of the cultural significance of spitting may also betray a Christian influence. $A$ check of the Thesaurus Linguae Latinae shows a preponderance of Christian authors. unsurprisingly discussing the Passion of Christ, in the use of such verbs as conspwo. as meaning to spit on someone in a show of contempt. See 4 THeSaurus LinguaE Latinae 503 (1906-09) (s.v. "conspuo"); 5 id. 752 (1910) (s.v. "despuo"). Even a gesture like spitting-treated as a universal form of abuse in FLYNN, supra note 26, at 16-can have various fortunes in various cultures. For a recent German spitting case, see HOHNEL, supra note 45 , at 28-29.

109. See LEUZE, supra note 60, at 66-68.

110. See id. at 68-72 (discussing the views of Windscheid, Jhering, and Kohler). 
worst elements [of society] would try to take advantage [of such a provision]. ${ }^{111}$

Thus the historical, and very un-Roman, hostility to money damages in affairs of honor became a part of codified German civil law; indeed, the limits of the drafters' idea of money damages for "nonmaterial" injuries can still be read on the face of the Civil Code, which allows money damages only in cases of bodily harm and what the common law calls "false imprisonment." 112 The classic cases of insult were excluded. The hostility to money damages thus hung on; civil actions in cases of insult were accordingly essentially impossible, ${ }^{113}$ and insult law retained the form of criminal law.

Moreover, as the passage from the drafters of the Civil Code just quoted suggests, the association of honor with the higher strata of society also hung on. It remained, throughout the nineteenth century, a prevalent belief that honor was something that appertained to the upper echelons of society. Only persons of high rank were, as the dueling literature put it, Satisfaktionsfähig, ${ }^{114}$ or capable of giving (and correspondingly of getting) "satisfaction" for a slight to honor. ${ }^{115}$ Such persons were no longer exclusively aristocrats in the nineteenth century. As Ute Frevert has noted, dueling became a great preoccupation of the higher bourgeoisie as well; ${ }^{116}$

111. B.S. MARKESINIS, A COMPARATIVE INTRODUCTION TO THE GERAIAN LAW OF TORTS 64 (1994).

112. See § 847(1) BÜRGERLICHES GESETZBUCH [BGB] [Civil Code] (F.R.G.). This provision reads:

Im Falle der Verletzung des Körpers oder der Gesundheit sowie im Falle der Freiheitsentziehung kann der Verletzie auch wegen des Schadens, der nicht Vermögensschaden ist, eine billige Entschädigung in Geld verlangen.

Ein gleicher Anspruch steht einer Frauensperson zu, gegen die ein Verbrechen oder Vergehen wider die Sittlichkeit begangen oder die durch Hinterlist, durch Drohung oder unter Mißbrauch eines Abhängigkeitsverhalltnisses zur Gestaltung der außerehelichen Beiwohnung bestimmt wird.

In the case of injury to the body or to health as well as in the case of false imprisonment, the injured party can also demand an equitable reparation in money for harm that is not monetary.

A similar claim is available to a woman, against whom a crime or a misdemeanor against good morals has been committed, or who has been led to permit extramarital sexual relations through trickery, threats. or through misuse of a relationship of dependency.

113. Under $\$ 188$ StGB, until 1974, judges could, however, make a quasi-civil award of damages to the injured party in an insult action; similar provisions, introduced by the Nazis in 1943 , remain the law in $\S \S 403-406$ StPO.

114. For Satisfaktionsfähigkeit as a "specifically German concept." sec FREVERT. supra note 91, at 13, 15. See also KEVIN MCALEER. DUELING: THE CULT OF HONOR IN FIN-DE-SIECLE GERMANY 49 (1994).

115. See FREVERT, supra note 91, at 76-88, 97-98, 179-96. For Enlightenment attacks on dueling as presupposing that aristocrats had more honor than others (including an attack by Adolph Freiherr von Knigge, the founder of German etiquette literature). see id. at $4 \mathrm{l}$.

116. See id. at 85 (describing "die soziale Ausweitung der satisfaktionsfahigen Gesellschaft") ("the societal expansion of the social class capable of satisfaction"). 
in that way, a kind of leveling up took place in the world of dueling. Nevertheless, the idea that there were higher and lower statuses, and in fact many grades from very high in honor to very low survived.

Indeed, the idea that there were varying grades of honor in society was sanctioned by statute. German statutes of the first decades of the nineteenth century differentiated carefully among the grades of "insultability" of persons of different social status. ${ }^{117}$ In tune with this theme of formal status inequality, the law of insult in the criminal codes of the various German states commonly aimed to guarantee that social inferiors would show proper deference. This brings us to a second function performed by the premodern law of insult. As I suggested earlier, laws requiring respect and deference are most commonly found in societies with well-articulated social hierarchies, like that of Confucian China. Premodern Germany society included just such articulated social hierarchies; in German law the doctrines of insult were expected to reinforce and safeguard hierarchical differences, just as comparable law in traditional China did. A statute of 1840 , for example, reads, typically:

[I]nsults ... are to be criminally punished in the following cases:

I. If the affront to honor [Ehrenkränkung] consists of a coarse physical assault [gröberen Thätlichkeiten];

II. if the insult is directed at persons to whom the insulter owes particular respect or deference [Achtung oder Ehrerbietung], on account of the insulter's social status or his relationship to the insulted persons .... ${ }^{118}$

117. See Allgemeines LANDRECHT FÜR DIE PREUßISChEN STAATEN VON 1794 [Prussian General Code], Teil II, tit. 20, $\$ \$ 607-636$ (noting the elaborate regulation of the varying degrees of "insultability" of persons of different social standing). This was abrogated by ordinance in December 1848. See REINHART KOSELLECK, PREUBEN ZWISCHEN REFORM UND REVOLUTION: ALLGEMEINES LANDRECHT, VERWALTUNG UND SOZIALE BEWEGUNG VON 1791 BIS 1848, at 102-03 (1967); see also Mittermaier, supra note 105, at $442-43$ (describing Hannoverian legislation). For a philosophical defense of status differences in legislation, see LUDwiG HARSCHER VON ALMENDINGEN, METAPHYSIK DES CIVIL-PROZESSES (Giessen, Müller 1821).

118. Criminalgesetzbuch für das Königreich Hannover [Criminal Code for the Kingdom of Hannover], v. 8.8 .1840 ch. 10 , art. 265 , reprinted in 2 SAMMLUNG DER DEUTSCHEN STRAFGESETZBÜCHER 140 (M. Stenglein ed., Munich, Keiser 1858). For other examples, sce Strafgesetzbuch für das Königreich Sachsen [Penal Code for the Kingdom of Saxony] 3, v. 13.8.1855, ch. 9, art. 240, reprinted in $3 \mathrm{id}$. at 111 (shielding those "whose position entitles them" to dishonor their victim from insult prosecution); and Strafgesetzbuch für das Großherzogthum Hessen [Penal Code for the Grand Duchy of Hesse], v. 17. 9.1841, tit. XXXVII, art. 309. reprinted in 2 id. at 134 (containing a provision similar to the provision quoted in the main text).

The Hannoverian criminal provisions, which in the case of repeated offenses carried punishment of up to two years' imprisonment in a workhouse (the worst form of imprisonment), would presumably not have been applied to any duelists who actually were induced to litigate rather than duel. Duelists would presumably have been subject to the technically noncriminal, and therefore less dishonorable, police provisions in Hannover, which provided for fines, and, more importantly, for the classic honor-oriented remedies of the retraction, apology, and declaration of honor. The Polizeistrafgesetz is reproduced in 2 id. at 139 n.53. 
It is in these statutes that we find what remains the key analytic term in the law of insult down to this day: Achtung, "respect." "Respect," in the German law of insult, thus began as hierarchical respect, long before it became the egalitarian respect of current law. More generally, the strong attachment to articulated social hierarchy of the early nineteenth century fostered a particular attitude toward the nature of insults-a tendency to understand the insult as an expression of disrespect, visited upon a person conscious of his right to be shown a polite, even exaggerated, respect at all times. Thus, early-nineteenth-century jurists found themselves discussing such problems as when it was an insult, in law, to fail to address a person according the formal title (for example, "Your Excellency," "Your Grace," or "Most Well-Born") to which his "rank and social status" entitled him. ${ }^{119}$

As for procedure, it was natural, in this honor-conscious culture, that both duelists and persons entitled to deference (if they went to court at all) ${ }^{120}$ should bring private prosecutions. A man of honor, even when he made use of the courts, was a man who settled his own disputes. Accordingly, affairs of honor, whether between duelists or between statussuperiors and status-inferiors, were not matters into which government magistrates should meddle too directly. The principle that the law of insult was a law of private prosecutions thus firmly established itself in the first part of the nineteenth century.

The tale of the making of the modern law of insult is a tale of the death of this old world of social hierarchy-of the replacement of the touchy aristocrat by the touchy German. How did that world of social hierarchy die in insult law? It died only slowly and, distressingly, largely in the midst of the revolutionary changes of the Nazi period-distressingly, for we might like to imagine that the end of the hierarchical law of insult in Germany was the product of the traditions of liberalism and of anti-

119. See 2 TITTMANN, supra note 103 , at 194 \& n.i. The art of employing such tilles correctly remained important throughout the late 19th century. For a list and discussion, see 2 JHERING, supra note 25 , at $414-21$.

To be sure, references to the problem of dueling as such became less frequent over the course of the century. While the association of the law of insult with dueling remained fresh for jurists of the early 19th century, that association faded in the literalure as the century wore on. Nevertheless, dueling itself retained a special status in German law. Unlike French law, which aimed to lower the status of the "aristocratic" duel by treating duels (to the extent that they were penalized) under the ordinary law of assault and murder, see ROBERT A. NYE, MASCULINITY AND MALE CODES OF HONOR IN MODERN FRANCE 134 (1993), German law continued to include special dueling provisions throughout the 19th century, and indeed, until 1969, see FREVERT, supra note 91, at 66-76. Penalizing a practice can even enhance its social status. And the values associated with dueling continued to make their influence felt on the law of insult.

120. Presumably they did so rarely. Presumably the laws on deferential respect were no more frequently applied than the laws on insult: High-status Germans would ordinarily have thrashed disrespectful inferiors, not taken them to court-just as they would ordinarily have dueled with status-equals. My point is not that these statutes were applied as written, but that they established a doctrinal tradition that has continued into the present. 
Fascism. Most of all, we might like to imagine that egalitarianism of respect was the work of Immanuel Kant, a man who unambiguously disfavored the hierarchical, honor-heavy society of his time. As Kant forthrightly declared in the late eighteenth century, pursuing his grand theme of the moral equality of all persons: "To show disrespect for others (contemnere), i.e., to deny them the respect [Achtung] we owe to each human being as such, is always a violation of our moral duty: For they are human beings." 121

The influence of Kant and his followers on German law is renowned, ${ }^{122}$ and one might expect that the decline of social hierarchy in German law represented Kantianism in action. Even if Kant were not the maker of status-egalitarianism in Germany, we might guess that anti-Fascism was. In the years after the horrors of the Fascist experience, honor was widely proclaimed as a universal value. Post-Fascist European law-especially constitutional law-regularly made a point of insisting that all human beings were entitled to equal honor; ${ }^{123}$ and one might suppose that it was the common postwar revulsion against Fascism that secured honor for all citizens.

Yet the tale is more complex, and its lessons are more morally ambiguous. The decline of social hierarchy in the German law of insult was, in considerable part, not a reaction against the Fascists, but the work of the Fascists; and if we do not understand that dark fact, I think we will find it difficult to grasp the deeper sociology, and the richer philosophical meaning, of "respect."

121. IMMANUEL KANT, METAPHYSIK DER SITTEN, reprinted in 8 IMMANUEL KANT: WERKAUSGABE 601 (1993) (1797) ("Andere verachten (contemnere), d. i. ihnen die dem Menschen überhaupt schuldige Achtung weigern, ist auf alle Fälle pflichtwidrig; denn es sind Menschen.”); $c f$. IMMANUEL KANT, KRITIK DER PRAKTISCHEN VERNUNFT, reprinted in 7 IMMANUEL KANT: WERKAUSGABE, supra, at 197 ("Fontenelle sagt: vor einem Vornehmen biicke ich mich, aber mein Geist biickt sich nicht. Ich kann hinzu setzen: vor einem niedrigen. bürgerlich-gemeinen Mann, an dem ich eine Rechtschaffenheit des Charakters in einem gewissen Maße, als ich mir von mir selbst nicht bewußt bin, wahrnehme, bückt sich mein Geist, ich mag wollen oder nicht, und den Kopf noch so hoch tragen, um ihn meinen Vorrang nicht ubersehen zu lassen.").

Yet even Kant's most famous follower in German criminal law could not banish socialhierarchical law from his discussion. See [ANSELM RITTER VON] FEUERBACH, LEHIRBUCH DES GEMEINEN IN DEUTSCHLAND GELTENDEN PEINLICHEN RECHTS 242-43 (Giessen, Heyer Ist ed. 1801). And in still later editions, though with altered wording, see for example, ANSELM RITrER VON FEUERBACH, LEHRBUCH DES GEMEINEN IN DEUTSCHLAND GULLTIGEN PEINLICHEN RECHTS 178-80 (Giessen, Heyer 10th ed. 1828).

122. See, e.g., 1 BONNER KOMMENTAR ZUM GRUNDGESETZ 7-10 (90th Supp. 1999) (emphasizing both Kantian philosophy and Christianity); William B. Ewald, Comparative Jurisprudence (I): What Was It Like To Try a Rat?, 143 U. PA. L. REV. 1889, 1997-2004 (1995). I leave aside the problem of Christianity in this Article. I observe only that Christianity can hardly account for the shifts of the last century and a half, since it has been present as a force for so much longer. That is not to say that European egalitarianism is not colored by Christianity. I think it is. But discussing that Christian coloration would simply be too difficult here.

123. See infra notes $166-168,254$ and accompanying text. 
How did we come, then, to the modern German world of equal honor for all? Status inequality disappeared from German law only by painful stages. It was in the 1870 s, a good ninety years after Kant's major philosophical works began to appear, that status inequality finally vanished from the statute books. ${ }^{124}$ With the new Imperial Criminal Code of 1871 , which included the provision on insult still in use today, came formal egalitarianism. ${ }^{125}$ Yet changing statutes is not the same as changing law, even in the civil-law world. Post-1871 jurists agreed that the provision on insult, despite its silence, continued to protect honor. As for the nature of honor, dominant opinion among the jurists refused to take statutory formal equality at face value. ${ }^{126}$ While there were some prominent voices in favor of egalitarianism in honor, ${ }^{127}$ dominant nineteenth-century juristic opinion

124. The Kingdom of Prussia formally abolished status differences in its law of insult after the Revolution of 1848, as did the Kingdom of Bavaria in 1861. These were the largest and most important states, but they were not all of Germany. In other states, the tradition of mandating deference was surprisingly long-lived. Only with Bismarck's grand unification of Germany in 1871, and the promulgation of a common criminal code in the same year. did the Prussian elimination of formal status differences in the law of insult prevail. See STRAFGESETZBUCH FUR DAS KÖNIGREICH BAYERN 1861, §§ 261-266; STRAFGeSETZBUCH FOR DIE PREUBisCheN STAATEN, §§ 152-163 (both without status distinctions).

125. So egalitarian, in fact, was the Empire's new criminal code that it did not even mention honor. Earlier statutes had classified insult as an Ehrenkrünkung, an affront to honor. The new Imperial Code dropped all such references. This did not prevent jurists, of course, from reintroducing honor as the standard term of doctrinal analysis.

126. Already a commentator on the formally egalitarian Bavarian statule of $1861 \mathrm{emphasized}$ that insultability had to be interpreted according to the "prevailing ideas and customs of the relevant status and professional circles." 2 DAS STRAFGESETZBUCH FOR DAS KONIGREICH BAYERN SAMMT DEM GESETZE VOM 10. NOV. 1861 ZUR EINFUHRUNG DES STRAFGESETZBUCHS UND DES POLIZEISTRAFGESETZBUCHS 104 (Ludwig Weis ed.. Nordlingen 1865). Indeed, in one respect social hierarchy remained even in the Imperial Criminal Code, which included special provisions protecting the honor of the Kaiser, the Landesherren, and the Bundesftirsten in $\$ \$ 94-$ 101 until the establishment of the Weimar Republic. See WILHELM HEULE \& FraNZ SCHIERLINGER, DAS STRAFGESETZBUCH FOR DAS DEUTSCHE REICH IN SEINER GEGENIVÁRTGGEN GESTALT 101-05 (Munich, Beck 1895). For a discussion of the reinstatement of $\$ 94$ at the close of the Weimar Republic, see infra note 141. A fuller discussion of the enforoement of respect in Germany would devote considerably more attention than I can here to the impontant question of law protecting heads of state, both domestic and foreign. Such law has also played a large role in popular German legal culture.

127. See, e.g., BINDING, supra note 91, at 24 ("Nach der Ehre bestimmt sich-so will das Recht-das Mindestmass des im Verkehr von Mensch zu Mensch zu wahrenden Anstandes, weil das Mindestmass von Achtung, das Jeder dem Andern schuldet:-insbesondere im ganzen grossen Verkehr mittels der Sprache. Die Ehre ist-richtiger nach ihr bemisst sich-der rechulich anerkannte Verkehrskurs eines Menschen.") ("Honor-such is the will of the law-determines the minimal measure of decent behavior in the intercourse of human beings, because it determines the minimal measure of respect that each owes to others-in particular in all of the great intercourse that is carried on by means of speech. Honor is-or rather. provides the measure forthe legally recognized commercial value in social relations of a human being."); id. at 25 ("Dank dem Christentum ist im Gegensatze zur Antike allmählich in der Geschichte des Rechts der Grundsatz von der Gleichheit aller Menschen als solchen zur Anerkennung gelangt.... Unser Ehrenrecht heute ist ganz demokratisch....") ("Thanks to Christianity, and in contrast to Antiquity, the basic principal of the equality of all men as such has gradually achieved recognition over the course of history .... Today our law of honor is wholly democratic...."). Even Binding, though, defended dueling between military officers. See id. at 30 . 
determined that honor, for legal purposes, had to be understood as external honor, or honor as measured according to the objective social valuation of a person. ${ }^{128}$ As an 1890 decision explained,

Every person has the right to claim a certain degree of respect [Achtung] from his fellow citizens .... As a general matter, the concept of the general valuation of persons [Werthschätzung] comprises all the types into which honor is customarily dividedthat is to say, honor associated with one's social status [die bürgerliche des Standes], sexual honor, and so on. These types of honor are specifically mentioned in order to show that the offense of injury to honor is not always measured according to the same standard, but differs according to the prevailing norms in the social circle of the person who has been insulted. ${ }^{129}$

This was a definition that left little room for those of low status, and correspondingly little room for meaningful realization of the formal equality of the statute. ${ }^{130}$ This was very far indeed from Kant's equal respect for all persons as human beings.

At the same time that jurists of the new Second Reich resisted equality in the substance of the law, they also resisted equality in procedure. In 1877, the new Imperial Code of Criminal Procedure appeared. Following hallowed practice, it ordained that cases of insult should be brought through private prosecutions. ${ }^{131}$ This had never troubled juristic commentators in the

128. An important countercurrent to the dominant school did begin to take shape as carly as the 1840 s. "Germanist" jurists-specialists in "German" rather than Roman law-began to press the claim that all Germans were entitled to a claim to honor. These Germanists remained, however, a distinctly minority voice in 19th-century juristic thought. The full acceptance of the idea that persons of all social ranks had enough honor that they could participate in the economy of insults came only later.

129. 38 ARCHIV FÜR STRAFRECHT 434, 435 n.4 (Berlin, Decker 1891).

Jede Person hat das Recht, einen gewissen Grad von Achtung bei seinen Mitbiirgern in Anspruch zu nehmen.... Im Allgemeinen umfaßt der Begriff der allgemeinen Werthschätzung alle verschiedenen Arten, in welche man die Ehre zu theilen pflegt, nämlich die bürgerliche des Standes, die Geschlechtsehre u.s.w., Arten, dic nur hervorgehoben werden, um zu zeigen, daß der Thatbestand der Ehrverletzung nicht überall dem gleichen Maßstab unterliegt, sondern sich nach den Anschauungen richtet. die in dem gesellschaftlichen Kreise des durch die Beleidigung Betroffenen maBgebend sind.

Id.

130. For the long-lasting tendency to analyze honor in hierarchical terms, sec Helmut Kohl, Das Lebach-Urteil in privatrechtlicher Sicht, in MEDIENWIRKUNG UND MEDIENVERANTWORTUNG 57 (Friedrich Kübler ed., 1975). German jurists brought, it should be said, plenty of their characteristic subtlety to their discussions. In particular, they rejected the proposition that social status as such conferred legally cognizable honor. Rather, honor came from fitness and uprightness in living up to the standards of one's social status. See MARKUS BREZINA, EHRE UND EHRENSCHUTZ IM NATIONALSOZIALISTISCHEN RECHT 25 \& 217 n.136 (1987).

131. Here there is a complication: While the Privatklage was regarded as penal in character. in some German states it was brought before a criminal judge, and in some before a civil judge. See, e.g., GeORG BeSElER, KOMMENTAR UBER DAS STRAFGESETZBUCH FÚ die PREuBischeN 
past. ${ }^{132}$ But with the establishment of the new, formally egalitarian law of insult, jurists set up a drumbeat of complaint about private prosecutions. ${ }^{133}$ Allowing private prosecutions for insult, jurists argued, almost with one voice, meant opening the courts to a flood of Bagatellsachen, "bagatelle cases" - trivial disputes that did not merit the attention of the legal system. This had never been a concern in an era in which the law of insult seemed to serve manifestly important purposes in the pursuit of properly founded claims of honor. Now, however, it became a constant refrain in the literature. ${ }^{134}$ If this juristic campaign against private prosecutions had succeeded, the law of insult could hardly have taken the form it takes today - a form in which, of course, ordinary Germans do believe that their "bagatelles" belong in court.

Before the modern law of insult could develop, in fact, two things had to happen. There had to be an embracing of the idea that everybody, of all social ranks, was entitled to a claim to honor, and there had to be a reaffirmation of the idea that ordinary lay Germans were entitled to their day in court, even with regard to their most ordinary claims.

Both things happened, and both happened largely in the Nazi period. Ideas about the broad social extension of honor circulated during the early twentieth century, and German jurisprudence did begin a slow process of change before Hitler seized power. During the Weimar era, it became common to acknowledge that inner honor, honor founded primarily on one's true moral worth, might occasionally play a role in legal analysis, as indeed might a general human dignity that applied to all. ${ }^{135}$ Nevertheless, throughout the 1920s, reigning juristic opinion still defined honor as external honor. ${ }^{136}$ At the same time, the sense of crisis over "bagatelle

STAATEN UND DAS EINFUHRUNGSGESETZ VOM 14, April 1851, at 333 (Lcipzig, Weidmann 1851). The draftsmen of the Code of Criminal Procedure rejected the latter. Prussian, practice, in favor of purely criminal treatment. See Deutscher Reichstag, I. Legislatur-Periode, II. Session 1874: Motive zum Entwurf einer StrafprozeBordnung und zum Entwurf des Einfuhrungsgesetzes, 231. The original $\S \$ 414-434$ StPO limited private prosecutions fundamentally to cases of insult and minor bodily harm. See LOWE-ROSENBERG, supra note 56 , at 7.

132. See, e.g., BESELER, supra note 131, at 333-37.

133. For the history of critique since the first appearance of the statute, see LOWEROSENBERG, supra note 56, at 14-15.

134. This was already the case in the earliest discussions surrounding the Code of Criminal Procedure. See RODIGER KOEWIUS, supra note 71, at 28-31 (describing the background in dueling norms). For this theme in the literature, see Eduard Kern. Der Ehrenschutz im knnftigen Strafrecht, in 1 MATERIALIEN ZUR STRAFRECHTSREFORM 303, 303 (1954).

135. Here jurists followed especially the theory of BINDING, supra note 91. Orthodox opinion found the idea of inner honor doctrinally difficult to accept, though; if moral worth was all that mattered, it was difficult to explain why it should count as an insult to ridicule someone's physical appearance or disabilities. See BREZINA, supra note 130, at 25. 1925):

136. See, e.g., LUDWIG F. EBERMAYER ET AL., ReICHS-STRAFGesetzBuCh 579 (3d ed.

Die einzelnen Begriffsbestimmungen treffen darin uberein, als sie die Ehre als Angriffsobjekt bezeichnen (vgl. allerdings Binding...). und zwar nicht den wegen seiner Innerlichkeit unverletzlichen, dem Rechtsgebiete nicht angehorigen inneren 
cases" grew. ${ }^{137}$ So strong, indeed, was this sense of an honor crisis in the courts that in late 1931, in the depths of the Depression and amidst the gathering thunder of the collapse of Weimar, the law of private prosecutions was actually the subject of emergency legislation. In October of that year, the Weimar government, beset not only by economic crisis but also by violent Nazi agitation throughout Germany, ${ }^{138}$ issued an "Emergency Ordinance for the Guarantee of the Economy and of Finance, and for the Suppression of Political Rioting and Agitation." 139 This ordinance, in an era of terrifying disorder, devoted two paragraphs to, of all things, cutting back on private prosecutions, which were overwhelmingly

Wert, die innere Ehre, sondern die äußere, den Wert, der einem Menschen innerhalb der menschlichen Gesellschaft kraft seiner Eigenschaften und Leistungen, also nach dem Maße der Erfüllung der ihm obliegenden sittlichen, rechtlichen und sozialen Pflichten zukommt....

Die den Angriffsgegenstand bei der Beleidigung bildende Ehre im vorerörterten Sinne kann die allgemein menschliche ... ehre sein.

The particular applications of the concept agree in designating honor as the object that is attacked (though compare Binding ...), and indeed not the inner value of inner honor, which because of its inward character cannot be injured, and which does not belong to the realm of law, but rather outer honor, the value accorded to a person within human society on account of his qualities and achievements, that is, according to the measure in which he fulfills his moral, legal, and social duties ....

The "honor" that constitutes the object of the attack in the law of insult, as just discussed, can be general human honor....

This debate in German jurisprudence recapitulated debates about the nature of honor that had been going on since the late Middle Ages. The state of Weimar jurisprudence is nicely summarized in BREZINA, supra note 130, at 24-25. To be sure, social hierarchy of the old-regime kind vanished from jurisprudence. See id. at 32 . Nevertheless, it remained "ein Phänomen des auBerjuristischen Bereichs," id., and as such was necessarily impounded into the "external" concept of honor.

137. From the time of the drafting of the modern Code of Criminal Procedure in the 1870s, the prospect of excessive private prosecutions for insult had troubled the drafters, and the Code accordingly included a special provision requiring that complainants in insult cases submit to mediation before bringing their claims. This did not prevent the number of cases from growing steadily. In the years 1921-1924, the requirement of mediation was extended to cover all minor offenses to privacy, property, and person. For the history, see LOWE-ROSENBERG, supra note 56. at 19-20, 66-68. This extension to the present catalogue, fully listed supra note 51, should not be regarded as taking private prosecutions outside the realm of honor. On the contrary, within the Hegelian tradition, all "trespasses" on the "personality" of individuals could be regarded as slights to honor. The modern catalogue of Privatklage offenses fits within this Hegelian concept of personality.

Who was bringing these cases? Frevert surmises that, as the practice of dueling faded after World War I, high-status citizens who would once have vindicated their honor through resort to arms tended to bring actions under the law of insult instead. For a discussion with a comparison to Poland, see FREVERT, supra note 91 , at 255, 335-36. For a once-famous prewar instance of an unsuccessful effort to bring an insult action by Karl May, the wildly popular author of westerns. see KARL MAY, MEIN LEBEN UND STREBEN 308-09 (1997); and Gerhard KlüBmeier. Ein Wind niedriger Gesinnung weht durch Deutschland, in JAHRBUCH DER KARL-MAY-GESELLSCHAFT 103 (Claus Roxin et al. eds., 1977).

138. On the crisis atmosphere that month, see GORDON A. CRAIG, GERMANY 1866-1945, at 557 (1978).

139. Dritte Verordnung des Reichspräsidenten zur Sicherung von Wirtschaft und Finanzen und zur Bekämpfung politischer Ausschreitungen, v. 6.10.1931 (RGBI. I S.537) (F.R.G.). 
about insult! $!^{140}$ Clearly enough, there was a powerful sense in the last days of the German republic that the legal system had not managed to adopt the right stance toward the honor problem..$^{\mid 41}$

The Nazi seizure of power, a few months later, brought to this atmosphere of crisis and confusion a fundamental reorientation of juristic thought. This reorientation had to do, first and foremost, with an insistence on the value of honor that was strongly egalitarian. There was an old line in German legal thinking, dating back the 1840s, that held that honor, and especially the gory honor of the teutonic forests, had to be the basis of any truly "German" law. ${ }^{142}$ Nazi legal thinkers made this line their own, declaring that honor would be the foundation of the newly reformed Nazi law. ${ }^{143}$ There was, it hardly needs to be said, nothing about Kant or the moral worth of all human beings in the Nazi theory of honor. In principal part, the Nazi idea of honor involved race honor, as "protected" through legislation criminalizing sexual relations between "Aryans" and "nonAryans." 144 But there was more to Nazi honor law than this famous bit. Remarkably, the Nazis tried to reintroduce the duel, and to insist that all Germans, of whatever social station, should be entitled to defend their honor by dueling. ${ }^{145}$ In an effort to safeguard the honor of the entire Aryan nation, Nazi jurists maintained, contrary to Weimar jurisprudence, that

140. See id. $\$ \S 7-8$, at $563-64$ (allowing cours to dismiss privalt prosecutions sua sponte). Section 8 exempted from coverage of the ordinance cases of unfair competition and infringement on intellectual property. Thus, the ordinance reached only minor cases of injury to person. property, and privacy, like insult and kindred offenses: minor cases of uninvited entry into the home (Hausfriedensbruch), insult, bodily harm, threats, disclosure of secrets of another, and harm to goods. For the contemporary statute, see LOWE-ROSENBERG, supra notc 56. at 891-92, which sets forth $\S 374$ StPO with commentary. Limitations on Bagatellsachen had been proposed by the Juristentag. For a description of the proposals and the wistful observation that cutting back on private prosecutions would cost some judges their jobs. see Emst. Bagatellsachen, in 23 DEUTSCHE RICHTERZEITUNG 288, 290-91 (1931) (for private prosecutions). The emergency ordinance did meet with some resistance. For the refusal of the cours to apply the ordinance retroactively, see Boehm, Strafsachen, 60 JW 3578-79 (1931).

141. The year 1931 also saw another emergency ordinance aimed at protecting the honor of persons in public life, and 1932 saw the introduction of a new subparagraph of the Criminal Code (\$ 94 Abs. 2) specially protecting the honor of the Reichsprisident. See BREZINA, supra note 130 . at 56. All of this could perhaps be taken as evidence of a grand "honor crisis" at the end of the Weimar Republic.

142. For further discussion, see James Q. Whitman, At the Origins of Lanv and the State: Supervision of Violence, Mutilation of Bodies, or Setting of Prices?. 71 CHI.-KENT L. REV. 41, 61-64 (1995), which discusses Wilda, who emphasizes that honor historically played a large role in Germanic law.

143. See, e.g., BREZINA, supra note 130, at 95-96: HANS FRANK \& RODIGER GRAF VON DER GOLTZ, NATIONALSOZIALISTISCHER EHRENSCHUTZ 4-5 (1938). For a dissidenL Nazi-era voice, See ALEXANDER GRAF ZU DOHNA, NEUE MITTEL DES EHRENSCHUTZES 59, 159.66 (1938).

144. See FRANK \& GOLTZ, supra note 143, at 6 (discussing the law of September 15, 1935, which was passed "for the protection of German blood and German honor").

145. During the 1930s, the Nazi regime reintroduced the duel for officers and students. See FREVERT, supra note 91, at 256-63. Not content with this traditional concept of the "satisfaktionsfähige" classes, though, Nazi thinkers insisted that all Germans were entitled to resort to the duel to defend their honor. See id. 
group insult was cognizable at law ${ }^{146}$-though the groups that the Nazis wished to protect against insult were, in the first instance, the S.A. and the S.S., the Party's private thug-armies. It is, indeed, an uncomfortable irony to discover that modern German law on group insult can be partly traced to a 1934 decision allowing the prosecution of a man who was overheard in a barber shop expressing the understandable view that the S.A. and the S.S. were "nothing but scum"147 — a statement, the court held, that was clearly suited to do serious damage to the honor [Ansehen] "of every member of these two associations." "148 The Nazis also upgraded honor in criminal law: Some Nazi jurists even proposed shuffling around the contents of the criminal statute book, listing offenses against honor ahead of offenses against the person or property. ${ }^{149}$ Finally, and most importantly for my purposes here, Nazi doctrinal analysis at last accepted the proposition that Germans of all social statuses participated in German honor, at least to some extent. Largely abandoning the old dichotomy between external and internal honor, the Nazis redefined honor as "national" honor-as the product of committed participation in the Volk-community. ${ }^{150}$ This "nationalization" of honor nicely paralleled a "nationalization" of honor that took place during the French Revolution, ${ }^{151}$ and it had some of the same

146. See, e.g., RG [Imperial Supreme Court], Entscheidungen des Reichsgerichts in Strafsachen [RGSt], 70 (1937), 140 (141) (F.R.G.); RG [Imperial Supreme Court], RGSt. 68 (1934), 120 (123) (F.R.G.).

147. RG [Imperial Supreme Court], RGSt, 68 (1934), 120 (123) (F.R.G.). I have translated "lauter Lumpe" as "nothing but scum," since the quaint word "rascals" fails to capture the impact of "Lumpe."

148. Id. at 123. The court concluded that "[d]ie S.A. und S.S. bilden endlich Personenmehrheiten, die aus der Allgemeinheit so deutlich hervortreten, daß der Kreis der beleidigten Einzelpersonen scharf umgrenzt ist." Id. at 124. This is the same standard still applied in determining whether groups such as Turks can be protected under the law of collective insult. See supra note 87 and accompanying text. I do not mean to claim that the German law of collective insult is an invention of the Nazis. It does seem important, though, to accent Nazism's understudied contribution. For a cautious postwar reference, without discussion of this 1934 case. see Arthur Kauffman, Zur Frage der Beleidigung von Kollektivpersönlichkeiten, 72 ZEITSCHRIFT FUR DIE GESAMTE STRAFRECHTSWISSENSCHAFT 418, 419-20 (1960), which briefly discusses the Nazi-era developments. The tendency to accord government agents the special protection of group insult law continues to this day. See supra note 87 and accompanying text.

149. See BREZINA, supra note 130 , at 95 (citing DENKSCHRIFT DES PREUBISCHEN JUSTIZMINISTERS: NATIONALSOZIALISTISCHES STRAFRECHT 80 (1933)).

150. See id. at 26-28.

151. See Norman Hampson, The French Revolution and the Nationalisation of Honour, in WAR AND SOCIETY 199, 199-212 (M.R.D. Foot ed., 1973). Hampson writes:

The rule of Napoleon was to show that revolutionary patriotism, shom of its democratic and egalitarian aspects and of its dedication to vertu, had assumed some of the characteristics of aristocratic honour and transferred them from the individual to the nation-state. The most respected members of society were once again the military men, but their obligations and rewards were dictated by the Emperor rather than by their own volition.

Id. at 211-12. 
revolutionary implications: At least potentially, every German was a person of honor. ${ }^{152}$

This generalization of honor had its consequences for the law of insult. Here too, the Nazis, who had something of an attachment to bourgeois good manners, ${ }^{153}$ insisted that all Germans should get satisfaction. ${ }^{154}$ To be sure, private prosecutions as such did not fit well with the Nazi idea of good government. Indeed, some Nazi jurists pressed on with the Weimar juristic campaign against "bagatelle cases," proposing to eliminate the legal right to bring full-scale private prosecutions. ${ }^{15 s}$ This did not, however, imply that Nazi jurists were ready to eliminate the law of insult entirely. On the contrary, it was far too much for Nazi opinion to suggest that ordinary Germans should have no means of vindicating wounded honor. What Nazi reform draftsmen of the 1930s proposed instead was a scheme that would have redefined insult claims as less than fully "legal," subjecting them to binding arbitration before a judge. ${ }^{156}$ Litigants would thus still find their way into court; they would simply lose the right to full-dress adjudication of their claims to honor. Even this reform turned out to shock Nazi opinion. It was overwhelmingly rejected by Nazi commentators, ${ }^{157}$ who insisted that honor was too important to be excluded from the ordinary criminal law; as one of them nicely put it, the proposed reforms would represent a concession to "an obsolete materialistic Weltanschauung." 138 Honor counted for too much to give way to the spirit of court reform. Private prosecutions did decline in numbers, as they had been doing for some

152. This was complicated by Nazi corporatism, which aimed to classify persons according to profession and to subject each person to a standard of "professional honor." See BREZINA. supra note 130, at 31-35. This of course involved differential statuses. Nevertheless, two aspects of Nazi corporatism made it more or less compatible with Nazi universalization of honor. First. Standesehre, professional honor, primarily imposed duties rather than conferring rights. See id. Second, the definition of staus, in corporatist theory, emphasized the commonality of high- and low-status participants as "producers" in a single industrial enterprise. This was intended to diminish, not enhance, class differences.

Mussolini attempted to establish egalitarian honor in Fascist Italy by "impos[ing] the informal voi rather than the more formal Lei." STANLEY G. PAYNE A HiSTORY OF FASCISM, $1914-1945$, at 238 (1995).

153. See GEORGE MOSSE, THE FASCIST REVOLUTION 20-21, 25 (1999).

154. Notably, Nazi reformers recharacterized the various branches of the law of insult as covering "Ehrenkränkungen," again a term dating to the old dueling culture. See BREzINA, supra note 130, at 96. For "Kränkung" in dueling terminology, see, for example, FREVERT, supra note 91, at 93. For a lengthy discussion of the problem of insult in the context of Nazi legal thought. see [Georg] Dahm, Das Feststellungsverfahren zum Schutze der Ehre, in DER EHRENSCHUTZ IM NEUEN DEUTSCHEN STRAFVERFAHREN 43 (Franz Güruner ed., 1937). I have not been able to see another text of the same period, FRIEDRICH BASSENGE, EHRE UND BELEIDIGUNG (1937).

155. See BREZnNa, supra note 130, at 131-32.

156. For a description, see id. at 143-49.

157. See id. at 149-51.

158. Erwin Noack, Buchbesprechung, 65 JW 2345, 2346 (1937), quoted in BREZNA, supro note 130 , at 150 . 
time. ${ }^{159}$ But the net effect of the Nazi debates was to reaffirm their importance-to reaffirm the belief that the doors of the courts should always be open to German claims of honor.

In procedure as in substance, it thus has to be said that the Nazis advanced the progress of honor in German legal thought; the general social democratization of honor was a part of the "brown Revolution," the real social revolution that accompanied Nazi rule ${ }^{160}$ and that was a fundamental force in the popular success of the Nazis. ${ }^{161}$ In a slow process of diffusion by which honor trickled down through the lower ranks of German societya process that began well before 1933 and that has continued after 1945the Nazis made a major contribution. Maybe it is even a measure of Naziera change that studies of the postwar years showed that insult actions in the 1950s were predominantly brought by Germans of the lower social orders. ${ }^{162}$

It was thus not so much Kant who was the reigning intellectual light of the initial successful broad extension of honor throughout German society; it was Nazi legal thinkers such as Georg Dahm and Hans Frank. This may

159. Interestingly, during World War II, the proposed Nazi reform was instituted for a period. See Dritte Strafrechtspflegevereinfachungsverordnung, v. 13.8.1942 (RGBI. I S.508) (F.R.G.). This was abrogated by the Gesetz zur Wiederherstellung der Rechtseinheit auf dem Gebiete der Gerichtsverfassung, der bürgerlichen Rechtspflege, des Strafverfahrens und des Kostenrechts, v. 12.9.1950 (BGBl. I S.455, 506) (F.R.G.). If the Nazi wartime ordinance had been left intact-as was surely possible-many of the complaints of the modern legal profession would have been satisfied, since the bringing of private actions would have been made more difficult.

160. See David Schoenbaum, Hitler's Social Revolution: Class and Status in NAZI GERMANY, 1933-1939, at 285-86 (1966) (noting that the Nazis created a perception of a new social equality despite the practical failure of the regime's programs). For an effort from the left to limit Schoenbaum's conclusions, see Detlev J.K. PEUKERT, InSIDE NAZI Germany: CONFORMITY, OPPOSITION AND RACISM IN EVERYDAY LIFE 246-47 (1982), which explores social divisions in Nazi society.

To be sure, the Nazis resisted the idea that money damages could appropriately satisfy the wounded honor; they preached instead for premodern remedies like the apology and the retraction. See FRANK \& GOLTZ, supra note 143, at 10. For Nazi reform efforts to allow proof of the falsity of insulting claims, see BREZINA, supra note 130, at 104-05, 137-39; to make allowance for apology and retraction, see id. at 116; to allow publication of the judgment as a "symbolic pillory," see id. at 117-18, which notes that under current law this is permitted only in cases that correspond roughly to common-law libel, see $\S 200 \mathrm{StGB}$. For a discussion of orienting judgments more broadly toward "reparation of reputation," see BREZINA, supra note 130, at 13334. On Nazi ideas about the pillory, see Whitman, supra note 21, at 1083-84.

161. As George Mosse sharply puts it,

We know that real wages fell in Germany and that the Italian workers and peasants did not materially benefit from the fascist regime. But it would seem that. to many of them. this mattered less than the gain in status. Those who have tried to prove otherwise apparently believe that material interests alone determine men's actions. MOSSE, supra note 153, at 38-39.

162. See DoERING, supra note 45 , at 60-62. Doering also notes that there were generally acquittals, in his sample, when the accused was of high social standing. especially under the doctrine of "Wahmehmung berechtigter Interessen," $\$ 193 \mathrm{StGB}$, normally used in cases of published defarmations. See DOERING, supra note 45, at 61. Manifestly, this represents a continuation of old hierarchical assumptions. 
seem an uncomfortable paradox. Nevertheless it is important to dwell, for a moment, on the Nazi episode.

I think the Nazi episode helps us to see something that the current German law of sexual insult ${ }^{163}$ also helps us to see: what a problematic and troubling concept respect is. The proposition that all persons should have honor and respect sounds beautiful, and it is beautiful. At the same time, the roots of honor and respect lie in some coarse and unflattering aspects of human psychology. As Georg Simmel and Erving Goffman famously observed, we have a strong instinct to think of honor as differential, to think that if I am entitled to respect it is because I am better than others. ${ }^{164}$ This instinct is so strong that forms of civility tend to have, at their heart, some vision of hierarchical superiority; and societies that are "respectful" societies will be, almost inevitably, societies in which the cultural traditions of social hierarchy are strong. This was the view of Montesquieu, and 1 think it is the right view. As he put it in The Spirit of the Laws, it is an error to imagine that civility has the sort of origins that most American commentators like to celebrate-origins in the need for people to live together harmoniously:

Men, born to live together, are also born to please each other; and he who does not observe the proprieties offends all those with whom he lives and discredits himself so much that he becomes unable to do any good thing.

But politeness does not customarily have its origin in such a pure source. It arises from the desire to distinguish oneself. We are polite from arrogance; we flatter ourselves that our manners prove that we are not common and that we have not lived with the sort of people who have been neglected through the ages. ${ }^{165}$

German honor, and more narrowly the German law of insult, also have an impure source. The German law of insult remained, in the 1930s, "polite from arrogance"; what the Nazi period did was to permit every German the privilege of arrogance. In that sense, it is no surprise that the generalization of honor to all "Germans," as the Nazis defined them, should have come at a time when certain people, "neglected through the ages," were identified

163. See supra notes $78-83$ and accompanying text.

164. For Simmel, especially for the shape of hierarchical ordering in differentiating socicties. see GEORG SIMMEL, Uber- und Unterordnung, in SOZIOLOGIE: UNTERSUCHUNGEN OBER DIE FORMEN DER VERGESELLSCHAFTUNG 160. 272-73 (1992). For Golfman. see ERVING GOFMMAN, The Nature of Deference and Demeanor. in INTERACTON RTUAL 47 (1967).

165. Charles de Secondat, Baron de Montesquieu, The Spirtt of the Laivs 132 (Anne M. Cohler et al. trans., Cambridge Univ. Press 1989) (1748). Montesquieu, I should note, uses "civility" differently from "politeness." "Civility" is for Montesquicu a set of invariant rules, the use of which actually inhibits flattery-a virue he sees at work in Chinese "civility." See id. at 317. "Politeness" is the freer form in use in 18 th-century France. 
as the targets of contempt for all. Respect has, at its heart, something to do with superiority and inferiority; and the broad extension of superiority for some almost inevitably meant an insistence upon the inferiority of others.

\section{HATE SPEECH AND INSULT BETWEEN “HONOR” AND "HUMAN DIGNITY"}

To be sure, the tale did not end with the Nazis. Postwar German law has continued on its long trajectory. Honor has continued to trickle down through all echelons of society, now reaching (at least theoretically) Jews and other minorities. Meanwhile, German legal thought has inched forward in the direction of a historic conceptual shift: a movement away from the value of honor and toward the value of human dignity. Nevertheless, it would be a mistake to imagine that the old days of honor are entirely past. On the contrary, honor-oriented thinking continues to haunt German legal doctrine on "human dignity," just as it haunts the everyday life of the law of insult.

There have been, of course, real and stirring changes over the last fifty years - but they are changes that have almost always taken place against the background of the old law of honor. At the close of World War II, there was a concerted effort to establish new norms of dignity. Thus, the new Italian constitution of 1947 sanctified "social dignity" for all. ${ }^{166}$ The German Basic Law of 1949 also guaranteed "human dignity" in its first article. ${ }^{167}$ Still and all, elsewhere in German constitutional thought an older terminology of honor hung on. ${ }^{168}$ In particular, the Basic Law continued to imagine that generalizing honor was what was needed for the healthy regulation of the public sphere: Its Article 5, Section 2 guaranteed personal honor against depredation:

(1) Every person has the right to express and disseminate his opinion freely .... (2) These rights [of free expression of opinion] find their limits in the provisions of the general laws, in the

166. See GiUSEPPE ARMANI, LA COSTITUZIONE ITALIANA 313 (1988) ("Tutti i cittadini hanno pari dignità sociale ...." (citing COSTITUZIONE [COST.] art. 3 (Italy)) ("All citizens have equal social dignity ....").

167. See GG [Constitution] Art. 1, para. 1 (F.R.G.) ("Die Würde des Menschen ist unantastbar.") ("Human dignity is inviolable."). For the accepted idea of the historical and intellectual background to this provision, see 1 BONNER KOMMENTAR ZUM GRUNDGESETZ, supra note 122 , at 1-65; and especially id. at $7-10$, for the prevailing tendency to emphasize the influence of Kantian tradition as well as of Christianity.

168. Article 2 of the German Constitution, in particular, drew on the Humboldtian tradition of thought about the freedom of "personality" in characteristically 19th-century ways. See GG Art. 2. 
determinations of the laws for the protection of minors, and in the right to personal honor. ${ }^{169}$

Clearly enough, this Section 2 presupposed the existence of the tradition of insult law whose history I have recounted: A constitutional law of "personal honor" could hardly fail to echo old ideas. ${ }^{170}$

Nevertheless, by constitutionalizing personal honor, the Basic Law did seem to promise some kind of transformation, and a measure of transformation has unquestionably resulted over the half century of social reconstruction following. In the law of insult, dominant postwar juristic opinion holds that "inner," moral, honor is a true measure-though jurists have an exceedingly difficult time explaining how the law could possibly protect inner honor. ${ }^{171}$ Human dignity, and in particular a Kantian analysis of human dignity, has indeed become a fundamental theme in German constitutional law. ${ }^{172}$ Other old battles have been won by the forces of change as well. In a famous 1958 case, known as the case of the Gentleman Equestrian, it was finally held that money damages were permissible in accordance with general principles of the protection of honor and human dignity incorporated in the Basic Law. ${ }^{173}$ This decision established at last the possibility of money damages, and so of civil "personality" actions for the redress of wounded honor. ${ }^{174}$ Most importantly for my tale, it marked an historic break - though a remarkably late one-with some of the values of aristocratic culture.

Nevertheless, despite many changes dating both to the Germany of Hitler and to the Germany of Adenauer, honor and respect are still values that originally sprang up somewhere outside our familiar world of general equality; the basic grammar of German legal doctrine is still, in sundry and

169. Id. Art. $5, \S 2$.

170. Since "personal honor" is still to be found in the Basic Law, German constitutionalists continue to wrestle with some very old traditions in the laws of insult (and the law of personality) in their efforts to find the right interpretive range for it. See, e.g., 1 BONNER KOMMENTAR ZUM GRUNDGESETZ, supra note 122, at 127-37 (discussing personal honor by reference to the historic law of insult and of personality).

171. For the difficulties, see Kübler, supra note 49, at 543 . For further discussion in the leading literature, see HIRSCH, supra note 78, at 2-3.

172. See, e.g., Wolfgang Graf Vitzthum, Die Menschenwilrde als Verfassungsbegriff, $40 \mathrm{JZ}$ 201 (1985).

173. Entscheidungen des Bundesgerichtshofes in Zivilsachen [BGHZ] 26, 349 (Urteil v. 14.2.1958, I ZR 151/56) (F.R.G.). For a full account, with discussion, see Edward J. Eberle, Human Dignity, Privacy, and Personality in German and American Constimutional Law, 1997 UTAH L. REV. 963, 1015; for continuing complaints that Germans remain too reluctant to award money damages, see DOERING, supra note 45 , at 123 . Eerily similar facts appear in the wellknown opinion of Learned Hand in Burton v. Crowell Publishing Co., 82 F.2d 154 (2d Cir. 1936).

174. For accounts of the state of German law, see Johannes Hager, Der Sehurz der Ehre im Zivilrecht, 196 ARCHIV FOR DIE CIVIISTISCHE PRAXIS 168 (1996); and Hans D. Janass, Die Entwicklung des allgemeinen Persönliclkeissrechts in der Rechtsprechung des Bundesverfassungsgerichts, in RECHT DER PERSONLICHKEIT 89, 103 (H.-U. Erichsen el al. eds.. 1996). 
sometimes strange ways, a grammar of the old language of social hierarchy. The tenacity of that grammar is something that we can see both in the law of insult generally and in the postwar history of hate-speech regulation more narrowly. Let me now turn to each of those topics in turn.

To begin with the topic of insult: Of course, the German law of insult has reached shores far from the old country of the eighteenth century. Insults are no longer prototypically offenses offered to honor-conscious aristocrats, who would regard the idea of money damages as shocking. But the everyday law of insult, in its current shape, has not escaped its origins. Quite the contrary. Achtung, "respect," remains the fundamental working term of insult jurisprudence; and in its workings, it is not Kantian respect. If Germans are no longer "polite from arrogance," as they perhaps still were in the Nazi era, they remain legally polite according to forms that date from eras of arrogance. Most strikingly, the remarkable strength of the dueling tradition continues to show in the very substance of what is considered an insult in German law. For, down to this day, the definition of the sorts of substantive insults penalized under the law of insult is, to a startling extent, still drawn directly from old dueling norms. In some cases, we hardly need even consult the dueling literature to guess that this is so. One of the standard examples of an insulting gesture, in German ${ }^{175}$ analysis, is still the Ohrfeige - the box on the ear, or insulting slap-famous as a duelist's gesture. It is presented, in current German doctrine, as an example of a Tätlichkeit, an aggravating act of physical violence. Tätlichkeit is today a somewhat out-of-the-way term that is seldom used in everyday German, ${ }^{176}$ but it had an established place in the literature of dueling. It is revealing to quote our commentary again, this time on the topic of Tätlichkeit, alongside a passage from a standard nineteenth-century dueling manual. The modern commentary reads as follows:

The statute introduces a qualification where the insult takes place by means of a physical assault [mittels einer Tätlichkeit], that is, an effect directed immediately toward the body which, according to its objective sense, expresses a particular lack of respect for the value and worth of the affected person (for example, spitting, slapping, cutting the hair, etc.). Since the basis of the qualification cannot be an intrusion into the integrity of the body, but merely the declaration of a particularly humiliating lack of respect for the affected person, it is not necessary that there be any actual bodily

175. And Italian. See Alberto Crespi et al., Commentario Breve al Codice Penale: $\S 594$, at 1355 (1992) (discussing the treatment of lo schiaffo).

176. Although Mr. Nikolas Eschen observed to me, in a personal communication of October 28,1999 , that "Tätlichkeit is often used in everyday German to describe intentional rudeness in a sports game outside a play-action, like slapping the opponent, spitting on him or ... to walk on somebody's knee." 
touching .... Even a slap that fails to hit its target can be an insult by means of physical assault, though not an immoral touching of the body of another person, insofar as that touching does not take place in a way that particularly diminishes the worth and valuation of the affected person [soweit dies nicht in besonders entwürdigender Weise geschieht $]. . .{ }^{177}$

This passage carries remarkable echoes of the old duelists' notion of the nature of insults. The old dueling literature was of course, for the most part, less juristically developed than the passage just quoted, but its view of the nature of human conflict was recognizably the same, as in the following German example from 1896, which goes well beyond the Tätlichkeit to include all manner of insults:

One distinguishes three grades of insult. The first grade is insult through words or writing, although this can also take place through a hand movement, through a disparaging gesture, or through a contemptuous sneer, when they are so understood by the parties.

A crude insult [eine Beschimpfing] is regarded as an insult of the second grade, whereas a blow, regardless of whether it is strong or weak, whether it is made defensively, or by accident fails to land, is characterized as an insult of the third grade.

Also in the category of insult of the third grade is the threat of a coarse insult by means of physical assault [die Androhung einer thätlichen Beschimpfung], the accusation of having committed a criminal act (fraud, theft, etc.), or the seduction of a family member. ${ }^{178}$

Remarkably much of the substance of this taxonomy survives, in one place or another, in the modern law of insult, including both accusation of a criminal offense and seduction of a family member. ${ }^{179} \mathrm{~A}$ lengthier account of the concept of the dueling insult, taken from a recent secondary work, gives a taste of how much the spirit of the dueling ethic lives on in the contemporary jurisprudence of insult, if in a less irascible form:

A duel was possible only where there had been an insult, of which there were three broad categories. The first classification was the simple slight [or insult] (einfache Beleidigung), constituted by impoliteness or inconsiderate behavior. The second level of insult

177. SCHÖNKE-SCHRODER, supra note 54, §185. at 1394. For a similar discussion. see 5 STRAFGESETZBUCH: LEIPZIGER KOMMENTAR: GROBKOMMENTAR $\$ 185.27$ (Hans-Heinrich Jescheck et al. eds., 10th ed. 1989).

178. H. KUFAHL \& J. SCHMIED-KowarzIK. DUELlBUCH 213 (Leipzig. Weberg 1896). For the original French model of this three-grade division, see CHATAUVILLARD, supra note 108, at 11-12.

179. See supra notes $65,78-79$ and accompanying text. 
was cursing or attribution of shameful qualities, examples of which might be calling someone an Esel (jackass) or Schwachkopf (imbecile). A tertiary offense was gravest and was rendered through a blow or a slap, the spectacular gauntlet-in-the-face falling under this heading, although they were rarely that hammy. To merely touch another's person qualified as a third-level offense, and if at a masked ball you were goosed by a tipsy soldier demanding a beer, the pinch that the Königsberg lawyer Ernst Borchert found himself in in 1896, a twenty-pace pistol duel with five exchanges was hardly an overreaction, though the rascal was dead by four. The violation of another's physical integrity was considered so reprehensible that even a threatened blow was regarded as an extreme offense, and so gentlemen would spare themselves the exertion by stating simply: "Consider yourself slapped!" The seduction or lewd touching of one's wife, daughter, sister, or other female dependent, could constitute a "blow," and similar actions or words that jeopardized one's entire moral being (as the phrase usually went) were also aggravated third-level insults, amenable only through bloodshed. ${ }^{180}$

Most of the wild excess of this world is gone of course-not least because no one is still willing to risk death as a result of an insult. On the other hand, it is disconcerting to acknowledge how many of these "dueling insults" still potentially count as insults under current law, from the use of the epithet Schwachkopf!, to the imputation of capacity to engage in criminal acts, and on down. It is also disconcerting to acknowledge how much of the calculus of whether those insults count as insults still depends on whether they attribute "shameful qualities" or the like to their target.

It is disconcerting, moreover, to note that the very operative terms of the modern-day law of insult remain dueling terms, held over without change since the nineteenth century. Ehre itself-honor-is of course regarded as the value protected by the statutory provision on insult (although the statute itself does not mention the term); perhaps there is nothing surprising in that. It is surely remarkable, though, that the law of insult continues to revolve around acts that are ehrenrührig, that "sully the honor," or that are Ehrenkränkungen, "affronts to the honor." 181 Jurists no longer use the old term satisfaktionsfähig, "capable of giving satisfaction"; but in the law of collective insult, they still discuss the problem of whether

180. MCALEER, supra note 114 , at 47.

181. For Ehrenkränkungen of the police, see BayObLG [Bavarian Court of Appeals], NJW, 43 (1990), 921 (922) (F.R.G.). German law also still speaks of Krankungen, "affronts"-for example with regard to Jews protected under hate-speech doctrine. See BVerfG [Federal Constitutional Court], NJW, 47 (1994), 1779 (1781) (F.R.G.) ("die kränkende Äußerung”). 
this or that group is beleidigungsfähig, "capable of being insulted." 182 This is, in fact, a remarkable development: Law that used to protect the Satisfaktionsfähigkeit of aristocrats now protects the Beleidigungsfahigkeit of Jews.

And at the heart, finally, of the conception of Beleidigung, of insult, there still lies a kind of high-society concept of civility-a concept that necessarily limits the reach of the German enforcement of respect. For "civil" behavior, in the thought-world of the law of insult, remains the kind of civility that was characteristic of upper-status behavior in centuries past: It remains civility that revolves around the highly formalistic, often thoroughly insincere, outward show of respect-even, as we have seen, in the socially charged contexts of the treatment of women and Turks.

This brings me at last to the topic that has intrigued American commentators the most: the rise of German hate-speech regulation. The postwar tale of the German law of hate speech is indeed a striking one, for this too is a body of law that has been marked by fifty years of troubled struggle over the cultural and doctrinal legacy of the old law of honor-so troubled that human dignity today threatens to vanish entirely as an expressly protected value.

Where, then, did Germany's much-admired hate-speech regulation come from? Over the first decade of the Federal Republic, hate-speech regulation remained essentially ${ }^{183}$ a matter of insult law, founded on the same $\S 185$ of the Criminal Code that is invoked against Germans who show "the bird" or call the wrong people $d u$, and on the same requirement of a private criminal prosecution. This was a body of law that had to be refashioned somewhat to serve its new "hate-speech" function: Creating a law of "collective" insult that covered Jews was a departure. ${ }^{184}$ Nevertheless, law of insult it remained, particularly in its focus on private prosecution. ${ }^{185}$ In the early years of postwar hate-speech regulation, the burden thus fell upon an "insulted" Jew to bring a private prosecution, in the classic way, to vindicate his wounded personal honor after he had been shown disrespect.

A wave of anti-Semitic agitation in 1959-1960 led, however, to an attempt to expand the conceptual range of the law. The classic analysis of

182. For the longest explanation of which groups qualify, see BGH. JZ, 44 (1989), 644, (645) (F.R.G.). The compound form "-fahigkeit" is of course common in German legal parlance (c.g., § 1 BGB: Rechtsfähigkeit, §104 BGB: Geschäftsunfahigkeir, §50 ZivilprozeBordnung [ZPO]: Parteifähigkeit). I do not mean to suggest that every instance in which it appears shows the persistence of the concept of Satisfaktionsfahigkeir. Nevertheless, the genetic connection between Satisfaktionsfähigkeit and Beleidigungsfähigkeit seems to me clear.

183. In this brief discussion, I focus only on the principal provisions dealing with hate speech. For a fuller account of the ensemble of laws applicable to acts that might be characterized as "hate speech," see Kübler, supra note 16, at 335.

184. See id. at 341 .

185. See Stein, supra note 16 , at 831. 
the direct, demeaning show of outward disrespect by individuals did little to deal with such evils as desecrated cemeteries. Such acts polluted the general climate of dignity without representing any individual show of disrespect. Accordingly, a new $\S 130$, on Volksverhetzung, "inciting the populace to hatred," was added to the repertoire of hate-speech provisions. This section, which reworked an older provision on incitement to class conflict, introduced two new concepts into the analysis of the hate-speech problem: "public peace" and, in tune with the postwar times, "human dignity":

Whoever attacks the human dignity of others in a manner that tends to disturb the public peace, by

(1) goading to hatred against segments of the population,

(2) demanding that violent or capricious measures be taken against them, or

(3) verbally abusing [beschimpft] them, maliciously exposing them to contempt, or slandering them,

shall be punished by a term of imprisonment from three months to five years. ${ }^{186}$

The idea of protecting public peace drew on some intellectual sources different from anything I have discussed in this Article. The idea of human dignity (which the drafters introduced in order to avoid naming any specific protected groups) ${ }^{187}$ might have been expected to guide the law of hate speech into new paths, pushing postwar law forward into a new world of dignitary thinking that would extend beyond the old culture of dueling, with its focus on the individual show of disrespect for the personal honor of another.

Yet the history of $\S 130$ StGB is a study in how deeply old patterns of thought about honor could continue to dominate German legal thought, despite all of the ambitions for a new law of human dignity. When the new section was passed, jurists understood that it was intended to establish human dignity as a different value alongside the honor protected by the law of insult. ${ }^{188}$ At the same time, they were thoroughly unsure what human

186. $\S 130 \mathrm{StGB}$. The section also covers printed materials that incite hatred, which I will not discuss here.

187. See Franz Streng, Das Unrecht der Volksverhetzung, in FESTSCHRIFt FúR KARL LACKNER ZUM 70 GEBURTSTAG 501, 504 (Wilfried Küper ed., n.d.).

188. See Josef Schafheutle, Das Sechste Strafrechtsänderungsgesetz, 15 JZ 470, 471 (1960). Schafheutle writes,

Zwar haben die Gerichte auf Grund der bisherigen Strafvorschriften gegen die Täter in den meisten Fällen auf Strafen erkennen können, dic Schwere des Unrechts und der Schuld entsprachen. Sie waren dabei aber vielfach auf die Beleidigungstatbestände angewiesen. Was sonst an Straftatbeständen noch in Frage kam, wie die $\$ \S 93,140,166,303,304$ StGB und die $\$ \S 4,28$ des Versammlungsgesetzes, war nur zum Teil mit dem Sachverhalt in Deckung zu bringen, konnte aber vor allem ebensowenig wie die Beleidigungsvorschriften den Kern des Unrechts treffen, um das es ging, nämlich den Angriff auf die Menschlichkeit, dic 
dignity could mean in practical terms. German constitutional scholars had developed, in the 1950s, a powerful body of Kantian thought on the nature of human dignity, which rested on subtle ideas of the distinction between exchangeable "value" and non-exchangeable "dignity." 189 These subtleties did not seem practical to the drafters of the new hate-speech regulation of $\S 130$; they felt the need to grasp at some more concrete conception. ${ }^{150}$

The tale of how they found their more concrete conception is a tale of the strengths of the old social traditions and of the consequent weaknesses of German hate-speech regulation: For, strange though it may seem, the draftsmen drew their concrete conception of human dignity from military law, a classic arena of honor-based thinking. In the wake of the horrors of the Nazi period, the Federal Republic's military Codes of Conduct and of Criminal Law had been amended to include provisions on "human dignity." Foreigners will assume that these provisions aimed to prevent a repetition of Nazi atrocities, ${ }^{191}$ but in fact their principal aim was different. German legislators wanted to guarantee the dignity of Germans, ensuring that they would be treated as citizen-soldiers, and not as underlings. The following language was the result:

Military Code of Conduct [Soldatengesetz] § 11. Obedience.

(1) A soldier must obey his commanding officers....

Disobedience is not present, when an order is not followed that injures human dignity .... ${ }^{192}$

Menschenwürde und den allgemeinen Rechtsfrieden, den es dagegen zu verteidigen galt, daß sich Ausbrüche des Hasses und der Intoleranz gegen cinzelne Gruppen von Mitbürgern richteten.

To be sure, courts were able 10 impose punishments against malefactors on the basis of previous criminal provisions that comesponded to the gravity of the evil and to the guilt of the deed. They were frequendy thrown upon the law of insult, however. As for other criminal law that came into question. such as $\$ \$ 93.140 .166 .303 .304$ SiGB and $\S \S 4,28$ of the law on public assemblies: Those provisions could only partly cover the facts of the cases, and above all they were as litule able as the law of insult to strike at the core of the evil, namely, the attack on humanity, on human dignity, and the general public peace, which had to be protected against outbreaks of hatred and intolerance directed against groups of fellow citizens.

Id. Jurists also, importantly, took human dignity to be a limiting principle in the jurispnudence of $\S 130$, specifying a sub-class of cases within those that threatened public peace. See Lohse, supra note 65 , at 1677 . Even as a limiting principle, human dignity should theoretically have been able to serve as the basis of a new jurisprudence.

189. For the influence of Kant on value and dignity, see the discussion and assessment of the ideas of Günter Dürig in Wolfgang Graf Vitzthum, Die Menschenwïrde als Verfassungsbegriff. $40 \mathrm{JZ} 201,205$ (1985).

190. See Streng, supra note 187 , at 504-05.

191. See, e.g., Craig R. Whitney, As the Battlegrounds Shifr, the Draft Fades in Europe, N.Y. TLMES, Oct. 31, 1999, at 3 (treating these provisions as determining when it is "correct" for soldiers to disobey orders, rather than when it is permitted).

192. § 11 SoldatenG. Gehorsam.

(1) Der Soldat muB seinen Vorgesetzten gehorchen.... 
Military Criminal Code [Wehrstrafgesetz] § 22. Binding force of an order; Mistake.

(1) [Disobedience] is not illegal, if the order is not binding, in particular if it . . injures human dignity .... ${ }^{193}$

Military Criminal Code [Wehrstrafgesetz] $\S 31$. Treatment that dishonors soldiers [Entwürdigende Behandlung].

(1) Whoever intentionally treats a subordinate in a way that dishonors him... shall be punished by imprisonment or punitive arrest of no less than two weeks. ${ }^{194}$

What did these new provisions mean? Their setting was the interaction between two individuals, the commanding officer and soldier, against the background of centuries of traditions requiring soldierly respect. Inevitably, therefore, the new provisions were understood as guaranteeing the individual show of respect. Indeed, "human dignity" in all three provisions was interpreted in a way that assimilated the "inhumane" order to a demeaning insult "sullying the honor": "An order injures human dignity if it encroaches ... deeply on the sphere of rights of the subordinate, on his honor, his status in the eyes of the world [Ansehen], his military position, his health, his life, his financial existence, etc...." 195 "An order wounds human dignity if it damages the dignity of the person receiving it or of a third party." 196 "Treatment that dishonors a soldier consists in behavior that consciously and seriously injures the human and soldierly dignity or the sense of honor [die menschliche und soldatische Würde oder das Ehrgefiihl] of the soldier.... Treatment dishonoring a soldier thus includes coarse insults [die grobe Beleidigung] ...." 197

In these commentaries, the value of "human dignity" was more or less smoothly melded into the value of honorable interaction. The primary arena of "dignity" was understood to be the world of one-on-one contact between officer and soldier-the classic arena of interpersonal interaction in which questions of "personal honor" had always presented themselves. Bizarrely enough, it was in this military law, so remote from the thought-world of

Ungehorsam liegt nicht vor, wenn ein Befehl nicht befolgt wird, der die Menschenwürde verletzt ....

193. § 22 WStG. Verbindlichkeit des Befehls Irrtum.

(1) In den Fällen der $\$ \S 19$ bis 21 handelt der Untergeben nicht rechtswidrig, wenn der Befehl nicht verbindlich ist, insbesondere wenn er... die Menschenwurde verletzt....

194. § 31 WStG. Entwürdigende Behandlung.

(1) Wer vorsätzlich einen Untergebenen entwürdigend behandelt... wird mit Gefängnis oder mit Strafarrest nicht unter zwei Wochen bestraft.

195. MARTIN RITTAU, SOLDATENGESETZ: KOMMENTAR 116 (1957).

196. HERBERT ARNDT, GRUNDRISS DES WEHRSTRAFRECHTS 191 (2d ed. 1966).

197. Id. at 220 . This passage did try to deepen the concept of human dignity by associating it with what separates men from animals. 
everyday race relations, that the drafters of the new hate-speech law of 1959-1960 thought they found practical content for their doctrine. ${ }^{198}$

The military model did not, of course, dictate all of the subsequent development of hate-speech law. Nevertheless, jurists continued to think of the human dignity question in the way that commentators on military law did: The paradigmatic violation of dignity remained, in their minds, the demeaning show of disrespect offered by one person to another. The result was some noticeable, and sometimes distressing, limitations on the reach of German hate-speech legislation. As a leading critic of the jurisprudence of $\S 130$ would complain twenty-five years later, the habit of looking to military law, and more generally to old-style ideas of personal honor, rather than to the great ideals of the constitution, survived. ${ }^{199}$ One consequence was the reasoning in the notorious problem I mentioned above: The problem of the tavern-keeper who posts a "No Turks Allowed" sign. To German judges accustomed to traditional concepts of honor, the question, even under $\S 130$, was necessarily whether such signs offered an intentional insult-whether they unambiguously gave the show of disrespect: "Since the slogans on these signs do not make it clear why Turks cannot enter the establishment, it cannot be determined whether Turks, in these signs, are declared to be less valuable members of the community or whether their right to life within the community is being challenged." 200

Signs that read "No Turks Allowed" would seem, to almost any American, to flout fundamental norms of equal access, regardless of the intent of the person posting them. ${ }^{201}$ Yet German judges were able to see these signs differently because they thought of dignity as something that was paradigmatically wounded when one person openly expressed his lack of respect to another. To the mind of the court, there had, in effect, to be

198. See Streng, supra note 187, at 505. These reforms play a role in German popular consciousness, as reflected in a recent novel about the Turkish experience in Germany. The scene here is laid in a military camp. Strikingly enough, it shows some of the same old sensitivity to bodily touching that characterized the old world of dueling: " 'Darf ich Sie Anfassen?' fragte einer der Unteroffiziere. Ein Vorgesetzer durfte nur durch den Inhalt seiner Befehle Gewalt anwenden-für direkte Berührungen brauchte er eine Erlaubnis. Es hing mit den Menschenrechten zusammen." "“ 'May I touch you?' asked one of the N.C.O.'s. A superior was only allowed to apply force through the content of his orders-for direct bodily contact, he needed permission. It was a human rights thing." STEN NADOLNY, SELIMI ODER DIE GABE DER REDE 60 (1990).

199. See Lohse, supra note 65 , at 1678 .

200. Id. These same standards made their way into the scholarly commentary on $\$ 130$ :

An attack on human dignity [for purposes of $\S 130 \mathrm{StGB}$ ] is present only when that attack is directed not just against the discrete rights of personality (for example, honor), but also when it touches a human being in the core of his personality. by presenting that human being, in disregard [Mißachrung] of the principle of equality, as of lesser value [unterwertig], and contesting his right to life in the community.

SCHOONKE-SCHRÖDER, supra note 54, §130, at 1107.

201. Contrast this with the discussion of American ton law infra note 326 and accompanying text. 
something like an old duelists' encounter-some act by which one person intentionally failed to make the outward show of respect to another-before the statute could be brought into play. Hate-speech regulation was accordingly not construed to require a general climate that guaranteed minorities an equal sense of dignity; it was understood as something like a more "humane" and philosophical law of insult. This left little room for a law of hate speech that would address itself to the deeper structure of social relations-indeed, no room even for a law of hate speech that would require tavern-keepers to take down signs excluding Turks.

Personal honor thus continued to set the tone for human dignity. That is not to say that German hate-speech legislation achieved nothing. It is only to say that, in building a law of human dignity, German lawyers had to work in the way that lawyers work: with the materials that their social traditions provide. The result, though, was a problem that has not gone away. German jurists still have not found a way to craft a concept of human dignity in hate speech that fully transcends inherited concepts of personal honor, and indeed seem to have lost the thread of human dignity entirely. In 1985 , dissatisfaction with $\S 130$ led to another round of statutory revision. This dissatisfaction had to do with the group that remains, in practice, the principal beneficiary of German hate-speech law: the Jewish community. It was unhappiness with the failure of courts to punish the "Auschwitz lie" that stimulated a redrafting of the Criminal Code. This time, though, the drafters concentrated simply on $\S 185$, the old provision on insult. Their strategy was to eliminate the requirement that a private prosecution be brought in order for an insult action to succeed. ${ }^{202}$ Thus, the law of insult made its way once again into the heart of hate-speech legislation. The Auschwitz lie problem, however, did not vanish. Continued distress at the failure of courts to punish adequately the Auschwitz lie led to yet another revision in 1994, this time of $\S 130$. This last revision, however, largely eliminated human dignity, transforming the provision into one primarily turning on "public peace." 203

What the future will bring is, of course, hard to say. For the moment, though, the tale of German hate speech is a tale of unsuccessful efforts to leave interpersonal honor behind and to enter a new legal world of social dignity. The logic, and to a large extent the law, of insult continue to form the socio-legal basis of German hate-speech regulation: The Beleidigungsfähigkeit of late-twentieth-century Jews, to say it again, remains largely the descendant of the Satisfaktionsfähigkeit of nineteenthcentury aristocrats.

202. For a detailed description, see Stein, supra note 16 , at 857-66.

203. See the account, with a translation of the new version of $\S 130$, in Kübler, supra note 16 , at $344-46$. 
The history of this descent of dignity, from aristocrats to Jews, is a history, I would like to note, that gives the lie to two of the deepest and most pessimistic commentators on German affairs: Friedrich Nietzsche and Max Weber. Nietzsche thought that aristocratic "rights" could never be successfully generalized in a democratic society. ${ }^{204} \mathrm{He}$ was wrong; what has happened in Germany is precisely that aristocratic rights have been generalized. Weber addressed the question of the "democratization" of aristocratic values in 1917, in the midst of World War I, at a time when social hierarchy remained firmly rooted in Germany. As he saw it then, aristocratic patterns of behavior could sometimes spread down through the social ranks in modern societies: "Beyond question, a true aristocracy can impress its ideal of noble behavior on an entire population. For the plebeian classes imitate aristocratic 'gestures." ${ }^{205}$ Yet he denied that anything quite like that could happen in Germany. He believed that German Satisfaktionsfähigkeit was a concept that could never be democratized. ${ }^{206}$ Weber, too, was wrong. Satisfaktionsfähigkeit has been democratized late in the twentieth century, and indeed has become the Beleidigungsfähigkeit

204. See FRIEDRICH NIETZSCHE, Jenseits von Gut und Böse, in 3 WVERKE: 660. para. 202 (Karl Schlechta ed., 1984) (describing anarchists and socialists as "cins im zithen Widerstande gegen jeden Sonder-Anspruch, jedes Sonder-Recht und Vorrecht (das heiBt im letzten Grunde gegen jedes Recht: denn dann, wenn alle gleich sind, braucht niemand mehr 'Rechte') ${ }^{\prime \prime}$ ) ("united in bitter resistance against every special claim, every special right and privilege (that is to say, in the last analysis, against every right: For when all are equal, nobody needs 'rights' any longer")).

For Nietzsche specifically on the process of the diffusion of civility, taking a version of what I will call the Hume line, see infra notes 366-370 and accompanying iext. See also FrIEDRICH NIETZSCHE, MENSCHLICHES, AllZUMENSCHLICHES. EIN BUCH FOR FREIE GeISTER 16165, para. 250 (Augsburg Goldmann 1981) (2d ed. 1886).

Manieren-Die guten Manieren verschwinden in dem Maße, in welchem der EinfluB des Hofes und einer abgeschlossenen Aristokratie nachlaBt .... Sollte es aber mit den Manieren immerfort bergab gehen? Es scheint mir vielmehr, daB dic Manieren eine tiefe Kurve machen und wir uns ihrem niedrigsten Stande nalhem. Wenn erst die Gesellschaft ihrer Absichten und Prinzipien sicherer geworden ist. so duß diese formbildend wirken (während jetzt die angelemten Manieren fruherer formen-bildender Zustände immer schwächer vererbt and angelemt werden), so wird es Manieren des Umgangs, Gebärden und Ausdrücke des Verkehrs geben, welche so notwendig und schlicht natürlich erscheinen müssen, als es diese Absichten und Prinzipien sind.

Manners-Good manners disappear to the degree that the influence of a court and a closed aristocracy declines.... But is it the case that manners should continue to go downhill forever? It seems to me, rather, that manners are declining in a curve. whose lowpoint we are approaching. Once society becomes more sure of its aims and principles, those aims and principles will create forms that correspond to them. (By contrast, the manners that we are taught now are the product of earlier circumstances. which created their own forms; those manners are inherited and learned in ever weaker ways.) In the future, there will be everyday manners. gestures, and expressions in intercourse that seem as inevitable and natural as society's aims and principles themselves.

Id.

205. MAX WEBER, Wahlrecht und Demokratie in Deutschland, in GESAMIMELTE POLTISCHE SCHRIFTEN 270 (3d ed. 1958).

206. See id. at 271-72 (contrasting the "democratizability" of French and German aristocratic patterns with the non-democratizability of Satisfaktionsfahigkeit). 
of ethnic and cultural minorities-most especially of Jews, who once upon a time tried unsuccessfully to defend their honor by inducing others to duel with them. ${ }^{207}$

The net consequence is that Germany has what we conspicuously lack in the United States: a true law of insult, founded in the protection of honor. The assumptions of an old aristocratic world have been translated into a democratic idiom. ${ }^{208}$

What should one say about this? The outlines of the legal history are clear enough: The law of insult, as it exists today, includes a number of more or less Roman elements, and a number of elements that are purely the confections of German legal thought. Still and all, what the law of insult represents is, in most regards, a large-scale generalization of dueling norms throughout German society. After a century and a half of development, the right to take offense, a right once confined to the "higher circles" of society, has become a right that belongs to all Germans. ${ }^{209}$ That does not mean that ordinary Germans perceive themselves as dueling aristocrats. The development is not one that is present to the minds of ordinary people. Nevertheless, it is a development that does seem to matter for the explanation of German law. In some ways, Germany does seem to have seen a leveling $u p$-an extension of aristocratic norms throughout what were once "lower" orders of society, and that is a phenomenon that calls for analytic discussion.

\section{THE FATE OF INSULt IN FRANCE}

In different ways, the same phenomenon can be found in France. French law also has an attachment to honor, and the French system, like the German, is correspondingly less solicitous of freedom of speech than is the American. Moreover, France, too, has a law of insult, historically connected with old-regime hierarchical forms; and in France, as in Germany, the law of insult forms the foundation of what, to some Americans, seems an admirable program for the regulation of hate speech. Nevertheless, taken as

207. Compare the episode in which Moritz Itzig tried, unsuccessfully, to draw Achim von Arnim into a duel that would establish the "Satisfaktionsfahigkeit" of Jews, described in DEBORAH HERTZ, JEWISH HIGH SOCIETY IN OLD REGIME BERLIN 258-59 (1988). For similar duels over Jewish honor in late-19th-century France, see NYE, supra note 119, at 205-10.

208. It is also important to observe that legal insults, like duels, happen overwhelmingly between status-equals. For insults, see DOERING, supra note 45, at 19-20; for duels, sec NYE, supra note 119 , at 167 , which elegantly argues that the status equality of dueling culture laid the foundation for new forms of French equality in the 19th century. See also FREVERT, supra note 91 , at 83 (noting the resistance to the idea that "lower" orders could duel).

209. In offering this interpretation, I should note that I differ from Professor Kubler, who argues that in modern society the concerns of free speech have come to trump old concerns of honor. See Kübler, supra note 49 . His argument may largely hold true of the law of defamation. I do not think it holds true of the law of insult narrowly understood, as regulated by $\$ 185$ StGB. 
a whole, the French law of civility is different from the German in revealing ways.

First of all, the narrow law of insult in France has today shrunk to almost total insignificance. Nonpublic insults-the classic dueling insults that are the main target of the German law of insult-are punishable only in summary police proceedings in France. In order for an insult to get into a French court of law, it must injure both honor and reputation. Only defamatory insults are matters for the "law," matters entitled to full-scale adjudication. Correspondingly, there is no legal culture of insult of the German kind in France. The state of this French law is my topic in this Part V.

But the French tale only begins with the decline of the law of insult. The decline of the law of insult has been accompanied, in France, by the rise of a culture of social norms of politeness. France today is the very model of a society in which matters of civility are governed not by law but by social norms-though, as we shall see, those social norms themselves have a remarkably lawlike flavor, and indeed are partly descended from one-time legal norms. The rise of this culture of distinctly legalistic social norms of politeness is my subject in Part VI.

To begin, then, with the law: There is, to be sure, still a law of insult on the books in France, just as there is in Germany. Indeed, the early history of the French law of insult reads much like the early history of the German law of insult. The French government was the most vigorous of early modern Europe in its efforts to force duelists to come into court. ${ }^{210}$ As in Germany, it was a consequence of the monarchy's campaign that French thinking about the law of insult was perforce connected with thinking about the problem of dueling. ${ }^{211}$ As in Germany, too, the law of insult was connected with larger questions of status and deference. In eighteenth-

210. The general history is recounted in BuLACols, supra note 104, at 95-111, 175-88. French legislation of the early modem period is conveniently reproduced in CHATAUVILLARD, supra note 108 , at $135-87,219-482$. As pan of its program, the monarehy set out to induce aristocrats whose pride had been wounded to litigate rather than fight. To this end. the monarchy established special "Courts of Honor" to adjudicate disputes. See Edit du Roi, Portant Reglement général sur les Duels, Aug. 1679, ar. 5, reprinted in CHATAUVILLARD, supra note 108, at 162. For the beginnings of this, see BILLACOIS, supra note 104, at 102. This program was, however, notoriously unsuccessful: Aristocrats refused to come to court. Indeed, their refusal provided a basis for the development of French social thought; figures like Montesquieu and Rousseau tried to explain why honor mattered so much, and why affairs of honor were not affairs of law.

211. See, e.g., Code Pénal ou Recueil des Principales Ordonnances, Edits et Déclarations, sur les Crimes et Délits, avec un Essai sur l'esprit \& les motifs de la Procédure Criminelle. Titre XXXVI: Des injures et des libelles diffamatoires, at cxlviii n.l (Paris, Chez Saillant \& Desaint 3d ed. 1765); see also Seconde partie. Texte des ordonnances, Edits \& Declarations, Titre XXXVI: Des injures et des libelles diffamatoires, Charles IX a Saint Germain en Laye, en Janvier 1561. art. XIII, at 247-48 (cross-referencing discussion of "insult" with discussion of ducling). 
century French doctrine, the law of insult naturally presupposed distinctions between persons according to their "quality." 212

For a time in the late eighteenth century, moreover, it looked as though the French law of insult might develop along the same path as the German law of insult. By the late years of the ancien régime, French authors had already begun to flirt with the critical idea that all persons, and not just aristocrats, were entitled to a legal claim for vindication of their honor. The idea of equality of honor before the law was particularly widespread in the last years before the Revolution. ${ }^{213}$ Social attitudes began to change, too, at

212. See, e.g., 1 FrançoIs SERPILlon, CODE CRIMINEL, OU COMMENTAIRE SUR L'ORDONNANCE DE 1670, at 368 (Lyon, Perisse 1767) ("La qualité de celui qui insulte, \& celle de la personne insultée, peuvent rendre les injures simples ou graves; le lieu, le temps \& autres circonstances, aggravent l'injure, ou la diminuent....") (“The quality of the insulter, and of the person insulted, can render insults simple or serious; the place, time, and other circumstances. aggravate the insult, or mitigate it ...."). Compare the Hannoverian statute, quoted supra note 118 , for the continuing vitality of these ideas in Germany down into the middle of the 19th century. Serpillon's text generally provides an overview of 18 th-century French procedures in cases of insult. See 1 SERPILLON, supra, at 368-78.

213. Thus, one 1781 author argued that the system of Courts of Honor, developed to deal with dueling aristocrats, should be extended, so that there would be Courts of Honor for cvery level of society. Jacques Vincent $M$. de la Croix, Réflexions Philosophiques sur l'origine de la Civilisation, Et sur les moyens de remédier aux abus qu'elle entraine tome 2 , no. 1, at 10 (Amsterdam, Belin 1781) ("Il seroit peut-être à désirer qu'un autre Tribunal érigé dans le même esprit, étendit son empire sur tous les Membres du Tiers-Etat....") ("It would perhaps be desirable that a court established in the same spirit have jurisdiction over all members of the Third Estate...."); id. at 16 ("[J]e ne verrois pas d'impossibilité à ériger dans toutes les Villes principales du Royaume un Tribunal Moral.") ("It does not seem impossible to me to establish a Court of Morality in the all the principal towns of the kingdom."). A leading criminal law text of 1780 opined that the deep attachment to honor in France meant that all persons must count as free "citizens":

Le caractère dominant de notre Nation est, comme l'on sçait, une extrême délicatesse sur le point d'honneur: délicatesse qui a pris vraisemblablement sa source dans cette maxime de notre Droit François, qui ne souffre point d'esclavage dans ce Royaume. \& qui veut qu'en naissans sujets du Roi, nous naissions tous libres \& citoyens.

The dominant character of our nation is, as is well known, an extreme delicacy with regard to the point of honor. This delicacy probably has its source in the maxim of French law, which refuses to suffer any slavery to exist in this kingdom, and which wills that, having been born subjects of the King, we should all be born free, and citizens.

MUYART DE VOUGLANS, LeS LoIX CRIMINELlES DE FRANCE, DANS LEUR ORDRE NATUREL 832 (Paris, Barrois 1783) (citation omitted). For an earlier statement by a non-lawyer, see MONSIEUR DE [ChampdevauX], L'Honneur, Considéré En Lui-Même, et Relativement au Duel 86 (Paris, Pierre-Alexandre le Prieur 1752) (“L'Honneur, quoiqu'en dise le préjugé, est de tous les états de la vie....") ("Honor, whatever inherited prejudice may say to the contrary, is the possession of all statuses of life ...."). Even the standard text on the law of insult, Dareau's Droit des Injures, made the same point, a bit more tentatively, in 1775. See F. DAREAU. TRAITÉ DES INJURES DANS L'ORDRE JUDICIAIRE 291 (Paris, Prault 1775). To be sure, Dareau did not set out to upset the entire hierarchical social structure of pre-Revolutionary France. Nevertheless, it was a major goal of his book to argue that all insults belonged in court. The logic that applied to aristocratic dueling applied throughout society: For just as aristocrats had to be brought into court so that they would not do violence, so others had to be brought into court so that they would not do violence. Dareau wrote of les gens du peuple, "people of no particular social standing":

Si un juge ne consultoit que les idées qu'on peut avoir des disputes entre gens de cette espèce, il seroit presque toujours tenté de les renvoyer hors du Cour \& du procès. Mais 
least in the urban forcing ground of Paris: Studies of the late eighteenth century suggest that low-status Parisians, unlike rural contemporaries from the south of France, believed that their honor should be vindicated against insult. ${ }^{214}$ The same idea continued to find promoters after the Revolution began, too-some of them of a wondrous and charming Revolutionary utopianism. ${ }^{215}$

Nevertheless, no such scheme was realized. To be sure, there was, as a number of scholars have observed, a kind of "nationalization" of honor

il doit faire attention que les injures entr'eux sont de conséquence. \& qu'aussi-tõt qu'elles demeurent impunies, elles amènent à des voies de fait souvent tr's-funestes.

If a judge consulted only prevailing notions about disputes between people of this ilk. he would almost always be tempted to throw out the case. But one must be mindful of the fact that insults between these people are of consequence, and that as soon as they go unpunished, they lead to often deadly acts of violence.

DAREAU, supra, at 291. For another example, sce I M. THORILLON, IDEES SUR LES LOIX CRIMINELLES 64 (Paris, Belin 1788):

Mais si je propose de substituer aux duels réparations honnêtes, telles que l'excuse devant les personnes témoins de l'offense, je ne proposerai jamais, comme le fait $M$. Vermeil, ... des réparations distinguées pour les uns: les Roturiers en allant chez les Nobles....

But if I propose to substitute reparations of good will for ducls. such as an apology made before the witnesses of the offense. I would never propose. as M. Vermeil does, ... different sorts of reparations for different people, with commoners required to present themselves to nobles....

The passage he attacks here is François-Michel Vermeil. Essai sur les Reformes a faire dans notre Législation Criminelle 115 (Paris, Demonville 1781), which proposes that a commoner who has insulted a nobleman be compelled to go personally to his victim to apologize in a public ceremony, while a nobleman who has insulted a commoner be permitted to make his apology before a notary and witnesses. For the special dishonorability of being compelled to visit another person, see James Q. Whitman, The Seigneurs Descend to the Rank of Creditors: The Abolition of Respect, 1790, 6 YALE J.L. \& HUMAN. 249 (1994). For imitation of aristocratic manners among the lower orders in the late 18th century, see YVES CASTAN. HONNETETE ET RELATONS SOCIALES EN LANGUEDOC (1715-1780), at 17-18 (1974).

214. See GARRIOCH, supra note 32, at 37-38 (contrasting his findings for Paris with those of CASTAN, supra note 213, at 260-61).

215. In 1791, for example, a cerain P.C. Nioche published a Motion avec Projet de Loi sur le Duel, et sur les injures et voies de fait entre Citoyens [Motion with Proposed Law on Dueling. and on Insults and Assaults Between Citizens] [voies de fair-the French equivalent of Tällichkeir]. This was a text that reviewed the long French tradition of punishing insults offered to and within the dueling classes, only to insist that, in the new order, " every citizen who, by words or writing. seeks to humiliate, degrade or abase another citizen" was to be subject to punishment under a Revolutionary law of insult. See P.C. NIOCHE, MOTION AVEC PROJET DE LOI SUR LE DUEL. ET SUR LES INJURES ET VOIES DE FAIT ENTRE CITOYENS 50-60 (Paris. Provosi 1791): see also [Target] Projet de Code Criminel, Correctionnel et de Police. Prísenté par la Commission Nommée par le Gouvernement, at xvii (n.p. 1801) (expressing nostalgia for honor and shame societies by stating, "Heureux ... les peuples où la honte seule, la perte de l'honneur et de la considération, la crainte de rencontrer dans les yeux de ses concitoyens des signes de mépris ou d'une opinion défavorable, sont une punition redoutée.") ("Happy... those peoples among whom shame alone, the loss of honor and esteem. the fear of discovering signs of contempt or of an unfavorable opinion in the eyes of their fellow citizens, are a dreaded punishment."); id. at xxxiii (proposing, inter alia, that acquitted defendants receive a medal inscribed "Innocence reconnue par la loi" ("Innocence recognized by the law") as a "témoignage d"honneur" ("testimonial of honor")); id. at 3 (describing shaming inscriptions on the tombstones of criminals). 
over the course of Revolution, as all Frenchmen were accorded a share in honor as long as they fought for the fatherland. ${ }^{216}$ In revolutionary France, as in Nazi Germany and perhaps almost everywhere, when honor became a common possession of all, it did so under the banner more of nationalism than of liberalism. But there was no parallel generalization of honor in the law. Proposals to include a "right to honor" in the 1789 Declaration of the Rights of Man and Citizen failed. ${ }^{217}$ Some radicals aimed at an egalitarianism of honor, ${ }^{218}$ but the term "honor" itself was so strongly associated with the old order that Jacobins tended rather to speak of replacing "feudal honor" with "virtue." 219

Only once the Jacobins were gone did the time come for insult legislation. But when that time came, it turned out to be a time, not for a new glorification of the law of insult, but for its harsh diminution. Legislators, perhaps still leery of something associated with the aristocratic world of dueling, produced a law that severely downgraded insult. In 1796, the government of the Directorate produced a Code of Crimes and Punishments. ${ }^{220}$ This Code declared a hodgepodge of offenses to be matters of "mere police," to be dealt with summarily before police tribunals without recourse to ordinary courts of law. Among these offenses were "verbal insults." 221 This led to at least one bitter complaint from a commentator who saw the Revolution as having given citizens whose honor had been wounded no recourse-and this, he said, despite numerous efforts

216. See GEOFFrey BEST, HoNOuR AMONG MEN AND NATIONS 18-36 (1982); GeORGe KELLEY, Dueling in Eighteenth Century France, in THE EIGHTEENTH CENTURY 251-53 (1980); Norman Hampson, La Patrie, in THE POLITICAL CULTURE OF THE FRENCH REVOLUTION 125. 134-36 (Colin Lucas ed., 1988); Hampson, supra note 151, at 211-12.

217. See BEIGNIER, supra note 13, at 86. For examples, see STEPHANE RIALS, LA DECLARATION DES DROITS DE L'HOMME ET DU CITOYEN 608 (1988) (setting forth a draft proposal of Target safeguarding "[l]a vie de l'homme, son corps, sa liberte, son honneur"). For proposals of Sieyès safeguarding the right of every citizen to defend "sa vie, son honneur, \& sa propriéte," see $i d$. at 618 . For a proposal holding that punishment must never reflect "de rang, d'état, ou de fortune" of the accused, see $i d$. at 623 . For an anonymous proposal safeguarding "existence ... liberté ... propriété ... HONNEUR," see id. at 630 .

218. For a discussion of the efforts of the sans-culottes to eliminate respectful greetings on the street, see SYLVIE WEIL, TREsoRS DE LA POLITESSE FRANÇAISE 7 (1983).

219. See NYE, supra note 119 , at 33 (quoting Mercier and Robespierre).

220. Heavily concemed with reestablishing order, this Code focused on court structure and the regulation of the police. See Code des Délits et Peines du 3 Brumaire, An IV (1796), in BULLETIN DES LOIS, Série 1, Tome 6, Livre I, $\$ \S 16-25$ (regulating the police); Livre II, $\$ \S 150$ 166 (establishing police tribunals); $c f$. Loi sur la police intérieure des communes de la République du 10 Vendémiaire, An IV (1796) (regulating police control of localities).

221. See Code des Délits et Peines du 3 Brumaire, An IV, $\$ 605$, no. 7 (“ [Sont punis de peines de simple police] [l]es auteurs d'injures verbales, dont il n'y a pas de poursuite par la voic criminelle."). Since the Revolutionaries had never defined what "injures verbales" might be subject to "poursuite par la voie criminelle," the meaning of the phrase is unclear. Presumably the phrase was effectively without meaning. See the description of the application of this law in SCIPION BEXon, PARAllèle du CODE PÉnal D'ANGleterRe aVEC les lois Pénales FRANÇAISES 238-44 (Paris, Fauvelle \& Sagnier, An VIII 1800). 
to introduce insult legislation. ${ }^{222}$ Such complaints had no effect; the drift of French legislation was set. Under the definitive criminal code of the Napoleonic period, the Code Pénal of 1810, most expressions of contempt were once again declared to be matters for the police-not "crimes" but "contraventions." Only a narrow class of public or published "insults"really cases of defamation, not insult - were to be considered crimes, and even those insults carried only a fine. ${ }^{223}$ Aristocratic honor just did not

222. See BEXON, supra note 221 , at 238-39:

Cependant, il n'existe point encore parmi nous depuis la névolution. de lois contre le calomniateur, quoique cette question imponante ait été présentée plusieurs fois au corps législatif et que j'aye entendu y répondre que ces lois étoient faites et que de nouvelles étoient inutiles; du moins, je n'en connais aucune ....

....

Le Code des délits et des peines du 3 brumaire an 4, est la scule loi qui parle de la calomnie; mais elle ne s'applique que sur la calomnie ou les injures verbales dont il n'y a pas de poursuites par la voie criminelle; et elle en attribue la connoissance aux tribunaux de police municipale .... A l'égard des injures ou des calomnies écrites, j' ai vu sans cesse les citoyens qui en étoient l'objet ne savoir où en demander la réparation et où pouvoir l'obtenir.

Enfin, après avoir long-temps cherché les moyens d'en obtenir justice ... on a été réduit à recourir à des demandes en réparations civiles, en recherchant les anciennes lois et en les invoquant contre les calomniateurs.

Meanwhile, since the Revolution, there do not exist, among us, laws against defamers and insulters, even though this important question has been presented to the legislative body several times, and though I have heard it said that laws of this kind had been made and new ones were of no use; in any case, I do not know of any ....

....

The Code of crimes and punishments of 3 Brumaire An 4 is the only law that speaks of defamation and insult; but it applies only to defamation or verbal insults which cannot be prosecuted by means of criminal law: and it accords jurisdiction to municipal police tribunals.... With regard to insults and written defamations, I have constantly witnessed citizens who have been the targets of such insults and defamations not knowing where to seek reparation and how to go about obtaining it.

Finally, after having searched long for ways of obtaining justice ... people have been reduced to seeking civil damages, by digging up old laws and invoking them against their defamers and insulters.

Honor, Iong regarded as the most precious possession of every Frenchman, was no longer important enough to merit full-scale litigation in cours of law. For the commonplace that honor was most precious, see, for example, VougLaNs, supra note 213, at 209 (" '[D]'un commun accord,' on dit que l'honneur est 'preférable à tous les biens de la vie." (") ("Iı) is universally agreed that honot is preferable to all goods in life.").

223. See CODE PENAL, EDTION CONFORM À L'EDmon ORIGINALE du BULLETIN des LoIS Livre III, Titre II, Chapitre I (Paris, Gaméry 1810):

375. Quant aux injures ou aux expressions outrageantes qui ne renferment l'imputation d'aucun fait précis, mais celle d'un vice déterminé, si clles ont été proférées dans des lieux ou des réunions publiques, ou insériés dans des écrits imprimés ou non, qui auraient été répandus et distribués. la peine sera une amende de seize francs à cinq cent francs.

376. Toutes autres injures ou expressions outrageantes qui n' auront pas cu ce double caractère de gravité et de publicité, ne donneront lieu qu'à des peines de simple police.

377. [insults proffered in the course of litigation]

378. [dissemination of confidential medical information]

375. With regard to insults or gross and outrageous expressions that do not include the imputation of any precise fact, but do include the imputation of a particular vice. 
matter enough in Revolutionary France to be of concern in the law. In fact, the real concern for "honor" in the 1810 Code lay elsewhere: Committed to maintaining government authority, the Code included a special provision protecting police officers and government officials from insults "tending to inculpate their honor or their délicatesse." 224 Insult law was more a matter of protecting the police against the public than of guaranteeing redress for wounded honor.

These Revolutionary enactments essentially created the French law of insult as it exists down to this day: The Revolution pushed the French law of insult into the category of a mere "police" infraction-one, moreover, largely aimed at protecting the honor, not of ordinary citizens, but of the police themselves. Post-Revolutionary developments never restored the French law of insult to its old glory. Honor, of course, continued to matter immensely in everyday nineteenth-century French life ${ }^{225}$ and

if they have been offered in public places or at public meetings, whether or not they have been inserted in printed writings that have been broadcast and distributed, they shall be punished by a fine of from 16 to 500 francs.

376. All other insults or gross and outrageous expression that do not have this double character of severity and publicity shall be subject only to simple police punishments.

377. [insults proffered in the course of litigation]

378. [dissemination of confidential medical information]

Id. Livre IV, Chapitre II, sec. I:

471. Seront punis d'amende, depuis 1 franc jusqu'à 5 francs inclusivement ...

11. Ceux qui, sans avoir été provoqués, auront proféré contre quelqu'un des injures, autres que celles prévues depuis l'art. 376 jusques et compris l'art. $378 \ldots$.

471. Punishable by a fine from one to five francs inclusively ...

11. Those who, without provocation, shall have offered to another person insults other than those contemplated in sections 376 to $378 \ldots$

224. Id. Livre III, Chapitre III sec. II, para. 222:

Lorsqu'un ou plusieurs magistrats de l'ordre administratif ou judiciaire auront reçu dans l'exercise de leurs fonctions, ou à l'occasion de cet exercise, quelque outrage tendant à inculper leur honneur ou leur délicatesse, celui qui les aura ainsi outragés sera puni d'un emprisonnement d'un mois à deux ans.

Si l'outrage a eu lieu à l'audience d'un cour ou d'un tribunal, il sera puni d'un emprisonnement d'un mois à deux ans.

If one or more officials of the administrative or judicial order receives, during the exercise of their functions, or on the occasion of the exercise of their functions, some gross insult tending to inculpate their honor or their délicatesse, the person who has insulted them in this way shall be punished by a term of imprisonment of one month to two years.

If the gross insult has taken place in the presence of a court or tribunal, it shall be punished by a term of imprisonment of one month to two years.

225. See generally NYE, supra note 119, at 180-81 (discussing social philosophy and social practice generally); WILLIAM M. REDDY, THE INVISIBLE CODE: HONOR AND SENTIMENT IN POST-REVOLUTONARY FRANCE, 1814-1848 (1997) (discussing the centrality of honor in early19th-century France). For early attempts to develop new protections for honor in the law, sce EMILE BEAUSSIRE, LES PRINCIPES DU DROIT 367-89 (Paris, F. Alcan 1888); and I A. BOISTIL, COURS DE PHILOSOPHIE DU DROIT 241-47 (Paris, A. Fontemoing 1899). For a general survey of 
law. ${ }^{226}$ Social hierarchy in particular did not vanish from nineteenth-century French legal analysis. ${ }^{227}$ Neither did dueling. ${ }^{228}$ But "mere" expressions of lack of respect or disrespect, such as are the stuff of the German law of insult today, became matters for the police. Only defamatory insults-

French attempts to defend the idea of a law protecting honor from the late 1880 s onward. see BEIGNIER, supra note 13 , at $44-47$.

226. See, e.g., JULES ROGER, DÉlITS DE PRESSE 103 (LOI DU 29 JUILLET 1881) (Paris, L. Larose et Forcel 1882) (discussing honor as one of the interests still protected by the limited law of insult).

227. This was emphasized by jurists reacting both to the laws of 1819 and of 1881 . For the latter, see JOSEPH ROUX, LA LOI DU 29 JUILLET 1881 ET LES DÉlTS DE PRESSE 123 (Paris, Amand Giard 1882):

La définition que la loi donne de l'injure est assez élastique pour que les juges puissent apprécier en toute liberté le caractère des injures; ils devront tenir compte en cela des circonstances de temps, de lieu, de dignité de la personne etc.... qui peuvent faire varier le sens des termes prétendus injurieux.

The definition of insult given by the law is rather elastic. in order that judges may be fully free to evaluate the character of the insults in question: in making their evaluation, they should take account of the time, the place, the dignity of the person, etc..... which can cause the sense of the allegedly insulting terms to vary.

See also WORMS, supra note 22, at 109, responding to the idea of reintroducing formal statusdistinctions into statutory law:

Est-ce que ... grâce à la marge laissée entre le minimum et maximum de la peine dont est frappée l'injure, le juge n'a pas le moyen de tenir compte de toutes les nuances, et de faire état, par exemple, tant du degré de culture de l'offensé que de celui peul-être fort différent de l'offenseur?

Is it not true that ... thanks to the range between the minimum and maximum penalty. the judge has the means to take account of all the nuances, and to factor in. for example, the degree of culture of the offended person just as much as the (perthaps very different) degree of culture of the person giving offense?

For the statute of 1819, see de Broglie's report to the Chambre des pairs in 1819, quoted in ROGER, supra note 226, at 100: "Les mêmes paroles ne sont point injurieuses à tous les degrés de l'échelle sociale. C'est au plaignant à établir ce qui est injure à son égard, au tribunal à le reconnaître et à le prononcer." "The same words are by no means insulting on all levels of the social scale. It is up to the plaintiff to establish what counts as an insult with regard to him; it is up to the court to recognize it and find accondingly."

228. See NYE, supra note 119, at 172-215. The "codes" of the duel were effectively incorporated into the law, as courts, despite the abolition of any special regulation for duels. convicted only duelists who had acted dishonorably according to accepted dueling practices. See $i d$. at 151-53. For the background to this development already in the 17th century, see id. at 25 . See also WoRMS, supra note 22, at 69-76.

Dueling was indeed, in the eyes of some French commentators, the locus of a generalization of honor throughout French society. As Worms put it:

Dans Jhering on lit que "le droit est la condition de l'existence morale, dont la deffense soutenue revient à la conservation morale de soi." (Autrement dit: je ne suis pas, je n'existe pas si je ne suis vengé.) Quant au droit dit de l'honneur, il cst le droil de la conservation éthica-sociale de soi. C"est avec raison que la démocratisation du duel, du duel sérieux que nous avons seul en vue, a été vantée, au delà même de nos frontières. comme un progrès égalitaire dans le sens des idées reformatrices de la France.

One reads in Jhering that "law is the condition of moral existence, and the defense of one's rights is a matter of one's own moral survival." (To put it differently: I am not. I exist not, if I am unavenged.) As for the right to honor. it is the right of ethico-social survival. It is for good reason that the democratization of the duel. of the serious duel. which is the only type we are considering, has been vaunted, even beyond our borders, as a matter of egalitarian progress in the spirit of French ideas of reform. Id. at 80 . 
"public" ones that included the "imputation of a fact" 229 -were deemed to merit litigation in court. The locus of honor was no longer insult but defamation-no longer testy "private" encounters between aristocrats, but defamatory "public" encounters that took place in the pages of newspapers. The old regime was, to be sure, not entirely gone. Defamatory statements were still defined, not only as injuring reputation (as in the United States) but also as injuring honor. ${ }^{230}$ Nevertheless, the old jurisprudence of respect had vanished.

The result, right up to the present, is a French law that looks much more like the kind of law that Americans are familiar with than does German law; American liberals will instantly feel more at home in France than they ever will in Germany. For, since French honor is now principally about defamation, ${ }^{231}$ the interest in honor is always balanced against the value of free expression. ${ }^{232}$ Honor questions in France, unlike Germany, have come to be regulated by statutes on the press-especially ${ }^{233}$ in an 1881 law, still

229. Or, still under the 1819 legislation, of a "vice détermine." See Loi sur la Répression des Crimes et Délits commis par la voie de la Presse, ou par tout autre moyen de publication (17 Mai 1819) Chapitre V. De la Diffamation et de l'Injure publique, para. 20, in BULLETIN DES LOIS, no. 278, at 469 (Paris, Imprimatur Royale 1819) [hereinafter Loi sur la Répression des Crimes et Délits commis par la voie de la Presse].

230. See, e.g., VITU, supra note 13, at 1574-75.

231. In the law of defamation in Germany, too, a balance between honor and free expression is always struck. See Kübler, supra note 16 , at 337 . My point in emphasizing French balancing is not to say that these values are never balanced in Germany, but rather to emphasize the consequences of the decline of the law of insult narrowly defined in France.

232. See Hauch, supra note 36, at 1236 (discussing the balancing of values and French law).

233. Though initially in a repressive enactment of 1819 , Loi sur la Répression des Crimes et Délits commis par la voie de la Presse. The law on insult:

Chapitre V. De la Diffamation et de l'Injure publique.

13. Toute allégation ou imputation d'un fait qui porte atteinte a l'honneur ou a la considération de la personne ou du corps auquel le fait est imputé, est une diffamation.

Toute expression outrageante, terme de mépris ou invective, qui ne renferme l'imputation d'aucun fait, est une injure.

19. L'injure contre [public officials engaged in public duties, ambassadors, and other envoys to the King] sera punie d'un emprisonnement de cinq jours à un an et d'une amende de vingt cinq francs à deux mille francs, ou de l'une de ces deux peines seulement, selon les circonstances.

L'injure contre les particuliers sera punie d'une amende de seize francs à cinq cents francs.

20. Néanmoins, l'injure qui ne renfermait pas l'imputation d'un vice déterminé, ou qui ne serait pas publique, continuera d'être punie des peines de simple police.

Chapter V. On Defamation and Public Insult.

13. Every allegation or imputation of a fact that affronts the honor or the esteem of a person or of the organization about which the fact is imputed, is a defamation.

Every gross or outrageous insult, term of contempt or invective, that does not include the imputation of any fact, is an insult.

....

19. Insults against [public officials engaged in public duties, ambassadors, and other envoys to the King] shall be punished by a term of imprisonment of five days to 
in effect today, which formed an integral part of the effort to bring true republicanism to France ${ }^{234}$ by safeguarding press freedoms. ${ }^{235}$ Because the law of honor in France has come to be classified as part of the world of newspaper reportage, French lawyers are accustomed to the idea that questions of honor are linked with questions of freedom of expression. In this, France looks quite different from Germany, where debates over the role of free expression in the law of honor remain much more problematic. ${ }^{236}$ In France, one is tempted to say, questions of honor have migrated fully into Habermas's "public sphere," whereas in Germany they have not. While the French law of honor once concerned the world of aristocratic respect and deference, it has come to concern overwhelmingly the world of journalism. Honor is no longer something primarily wounded

one year and by a fine of 25 to 2000 francs, or by one of these two punishments alone, according to the circumstances.

Insults against private persons shall be punished by a fine of 1610500 francs.

20. Nevertheless, insults that do not include the imputation of a determinate vicc, or that are not public, shall continue to be subject to simple police punishments.

Cf. Law No. 12,390 of Mar. 25, 1822, Loi relative à la Repression et à la Poursuite des Delits commis par la voie de la Presse ou par tout autre moyen de publication (establishing further repressive measures).

234. See BEIGNIER, supra note 13, at 151; NYE, supra note 119, at 175-76.

235. The current version appears at Presse et Communication, Loi du 29 juillet 1881. Appendix to Nouveau CODE PéNAL art. 29, 1905, 1933 ch. IV (96th ed. Dalloz 1999) (Fr.) [hereinafter C. PÉN.]: Des crimes et delits commis par la voie de la presse ou par tout autre moyen de publication.

(ord. 6 mai 1944) Toute allegation ou imputation d'un fait qui porte atteinte à l'honneur ou à la considération de la personne ou du corps auquel le fait est imputé est une diffamation. La publication directe ou par voie de reproduction de celte allégation ou de cette imputation est punissable, même si elle est faite sous forme dubitative ou si clle vise une personne ou un corps non expressément nommés, mais dont l'identification est rendue possible par les termes des discours, cris, menaces, Ecrits ou imprimes, placards ou affiches incriminés.

Toute expression outrageante, terme de mépris ou invective qui ne renferme l'imputation d'aucun fait est une injure.

Every allegation or imputation of a fact that affronts the honor or the esteem of a person or of the organization about which the fact is imputed is a defamation. The publication, whether direct or by means of reproduction, of such allegation or imputation is punishable, even if it is made in dubitative form or if it is aimed at a person or an organization not expressly named, but the identification of which is made possible by the terms of the discourse, ejaculations, threats written or printed, placards, or posters subject to prosecution.

Every gross insult, term of contempt or invective that does not include the imputation of any fact is an insult.

On the abandonment of the Napoleonic "vice détermine" standard, sec C. BAżLE \& ChaRles CONSTANT, CODE DE LA PRESSE: COMMENTAIRE THÉoRIQUe \& PRATIQUe DE LA LOI DU 29 JULLET 1881, at 204 (Paris, A. Durand \& Pedone-Lauriel 1883) (" La Loi de 1819 exigeait l'imputation d'un vice déterminé, ce qui donnait lieu, en jurisprudence, à d'assez grandes difficultés; aujourd'hui, l'injure existe encore bien qu'il n'y ait pas imputation d'un vice déterminé, il suffit qu'on ait constaté une parole ou terme de mépris à l'égard d'un individu."). For later developments, see VITU, supra note 13, at 1575-98.

236. See C. PÉN. (96th ed. Dalloz 1999) (commentary by Yves Mayaud), app. Presse et Communication, law of July 29,1881, at 1946, para. 106 ("L'incrimination d'injure touche, dans tous les cas, à la liberté d'expression telle que la réglemente cette loi ...."). 
within the confines of high "society," where information passes through gossip and rumor. Honor is now something wounded in the open spaces of modern "society," where information passes through mass media, and where what matters is not just individual status but also the contest for political preeminence. ${ }^{237}$ As a result, the casual American reader might conclude that France is much more an American-style liberal democracy than is Germany. France, an American might think, had a liberal revolution like our own, and French legal thinking therefore acknowledges the importance of free expression.

The casual reader should hesitate, though, before concluding too much. While free expression does matter a great deal in France, honor remains a value that outweighs the value of freedom of expression in many cases. ${ }^{238}$ The persons protected against "legal" insults are, moreover, still carefully defined to include government officials; French insult law is law intended to guarantee respect for the government. ${ }^{239}$ Most especially, it is intended to

237. In the 19th century, correspondingly, dueling became an aspect of the lives of French journalists, who were regularly challenged on account of the "insults" they had printed. See NYE. supra note 119, at 138-39, 187-90. For the similar obligation of American journalists to duel, sec WYATT-BROWN, supra note 39, at 356; and Mark Schmeller, Eating Fire: Journalistic Combat in Antebellum America (Apr. 29, 1999) (unpublished manuscript, on file with The Yale Law Journal).

For historiography tracing the rise of French "public opinion" in the 18th century, and insisting on the importance of that rise, see Keith Baker, Politics and Public Opinion Under the Old Regime: Some Reflections, in PRESS AND POLITICS IN PRE-REVOLUTIONARY FRANCE 208- 14 (Jack Censer \& Jeremy Popkin eds., 1987); and JÜRGEN HABERMAS, STRUKTURWANDEL dIR ÓFFENTLICHKEIT 133-41 (1990), which discusses France and Germany.

238. Honor is not a constitutionally sanctioned value in France, see BEIGNIER, supra note 13. at $88 \mathrm{n} .4$, but it is at all times balanced against the interest in free specch, see Hauch, supra note 36 , at 1236 .

239. See C. PÉN. art. 433-35 (96th ed. Dalloz 1999):

Constituent un outrage puni de $50000 \mathrm{~F}$ d'amende les paroles, gestes ou menaces, les écrits ou images de toute nature non rendus publics ou l'envoi d'objets quelconques adressés à une personne chargée d'une mission de service public, dans l'exercice ou à l'occasion de l'exercice de sa mission, et de nature à porter atteinte à sa dignitć ou au respect dû à la fonction dont elle est investie.

Lorsqu'il est adressé à une personne dépositaire de l'autorité publique, l'outrage est puni de six mois d'emprisonnement et de $50000 \mathrm{~F}$ d'amende.

Words, gestures, or threats, writings or images of any nature that are not made public, or the sending of objects of any kind addressed to a person charged with a mission in public service, during the exercise or on the occasion of the exercise of that mission, of a nature to affront the dignity or the respect due to the function with which that person is invested, constitute an outrage, and shall be punished by a fine of 50,000 francs.

When such outrage is addressed to a person who is the holder of public authority, it shall be punished by a term of imprisonment of six months and a fine of 50,000 francs.

Note the acute observations of Roger on the consequent state of affairs, in which government officials were effectively the only persons protected in law against insults:

Vous rencontrez un individu dans la rue, vous l'insultez, ou encore une polénique s'engage sur un livre nouveau, peu à peu, elle s'échauffe, elle s'envenime, on en vient aux allusions méchantes, à des expressions trop vives, à l'injure. Puis un beau jour vous apprenez que votre adversaire est un magistrat, qu'il veut porter plainte, est-ce que [Art. 33 , sec. 1 of the Loi du 29 juillet 1881] est applicable? 
guarantee respect for police officers, who have been darlings of French law since the Napoleonic period. ${ }^{240}$ The government gets the benefit of the protection of honor in a way that the American liberal tradition would never tolerate. France remains a land of honor of a kind the United States simply is not.

Still and all, if France remains a land of honor in the law, it must be underscored that it is not quite a land of honor like Germany. French law is no longer meant to protect persons insulted in casual, private encounters. ${ }^{241}$ This means that the law of insult in France has come to exclude what remains the principal stuff of the law of insult in Germany. Nobody in France is prosecuted for calling someone else $t u$ rather than vous. In France, the old law of "nonpublic" insult, once used to penalize the sort of expressions of disrespect that gave rise to duels, became, after 1796, a new law involving something very close to the issuance of parking tickets. Such is the form it retains. ${ }^{242}$ Today "nonpublic" insults are defined in the Code as the lowest level of "police" offense, calling for the imposition of a fine of no more than 250 French francs (about forty dollars) when they have not been "provoked." 243

À Rome, l'affirmative n'eût pas été douteuse ... : mais aussi il n'y avait pas de ces surprises, les Romains étaient toujours revêtus des insignes de leurş charges. Outrager l'homme, c'était outrager la robe, l'autorité.

You meet an individual in the street, you insult him. Or there is a heated discussion over a new book; little by little, the discussion heats up, it becomes envenomed. one progresses to nasty allusions, to expressions that are a bit too sharp, to an insult. Then one fine day you leam that your adversary is a magistrate, that he is initiating an action. Is this law [Art. 33, sec. 1 of the law of July 29, 1881] applicable?

In Rome, there would have been no doubt about the affirmative case ... : but there would not have been any surprises either. The Romans always wore the insignia of their offices. Insulting the man was insulting the robe, the authority.

ROGER, supra note 226, at 105-06. In France, by contrast, the official position of magistrales had to be signaled by their engagement in official duties before liability could arise. See id. at 106 .

240. The discussion by Joseph Roux, for example, is concemed disproporionately with insults to public officers. See RouX, supra note 227. at 116, 123.127: WORMIs, supra note 22, at 97-99. See generally HENRI PRUDHOMME, DE LA COMPÉTENCE EN MATÉRE DE Dé.ITS D'OUTRAGES PAR PAROLES ENVERS LES MAGISTRATS ET FONCTIONNAIRES (Paris. n.p. 1883).

The contrast with Germany is revealed in the categories used by French national statisticians. Where Germans have long kept figures on Beleidigung, the Anmuaire Statistique de la France tallies only "Outrages et Violences à dépositaires de l'autorité." See, e.g., L'INSTITUT NatioNal DE LA STATISTIQUE ET DES ETUDES ECONOMIQUes, ANNUAIRE STATISTIQUE DE LA FraNCE 1994, tbl.P.01-1, at 857 (1994) (Infractions constatées par les services de Police et de Gendarmerie) (métropole).

241. For complaints about this state of affairs, see the remarks of the Belgian magistrate, $M$. Limelette, quoted in WORMS, supra note 22, at 111 ; " $L$ 'injure devient-elle done anodine, sans danger, partant, parce qu'elle n'aura pas de publicité ... ?"”

242. There were similar developments in Germany, presumably under the influence of French law, in the early 19th century. But even "police" measures in Germany remained much more lawlike than they were in France.

243. See C. PÉN., Contraventions, ar. R. 621-2 (96th ed. Dalloz 1999) (“L'injure non publique envers une personne, lorsqu'elle n'a pas été prócéséc de provocation, est punie de l'amende prévue pour les contraventions de la $1^{\prime \prime}$ classe.") ("A nonpublic insult against a person. if it has not been preceded by a provocation, shall be punished by a fine contemplated for 
This is as nothing compared to the German law of insult. What is more, even what is found in the Code overstates the importance of the French law of insult as it exists today. It seems doubtful that either species of insult, public or nonpublic, is often prosecuted, at least outside of the context of "racist" speech. It is a matter of formal policy in France that prosecutors do not generally pursue matters of legal, public insult. ${ }^{244}$ As for nonpublic insults, it seems very likely that the police do not take notice of those either-unless the insults in question are offered to officers of the law. Indeed, aggrieved persons are formally encouraged, in France, to seek mediation of any dispute arising out of an insult, on the assumption that the police simply do not involve themselves in such things any longer. ${ }^{245}$

That is not to say that the law of insult in France has no life whatsoever. Certain defamatory insults do seem to end up in court. These involve, most especially, instances in which one person has called another, in one way or another, a "Fascist." ${ }^{246}$ (One also finds a variety of defamation cases in which Frenchmen have been "insulted" through public references to their

contraventions of the first class."); id. Peines, art. 131-12. ("Les peines contraventionelles encourues par les personnes physiques sont: $1^{\circ}$ L'amende ...") ("Punishments for contraventions incurred by the physical person are: (1) Fines ..."); id. art. 131-13 ("Le montant de l'amende est le suivant: $1^{\circ} 250 \mathrm{~F}$ au plus pour les contraventions de la $1^{\text {re }}$ classe ....") ("The amount of the fine is the following: (1) 250 francs at the most for contraventions of the first class . ...").

244. See Sénat, Session Ordinaire de 1997-1998, Annexe au procès-verbal de la séance du 18 juin 1998, Rapport d'Information ("Traditionnellement, les magistrats du Parquet ne prennent jamais l'initiative des poursuites en matière de diffamation et d'injures concernant les particuliers.") ("Traditionally, prosecutors do not take the initiative in pursuing defamations and insuits against private persons.").

245. See, for example, the literature of the Service Médiation, Chaussée de Nivelles, Paris. which acknowledges that the French police simply do not involve themselves in the sorts of insults that play such a large role in Germany:

Trop de gens se permettent d'agresser verbalement ou physiquement la ou les personnes qui les interpellent avec toutes les conséquences désobligeantes sinon dramatiques qui peuvent s'ensuivre. La police, quant à elle, n'a pas toujours les moyens de s'investir dans ces litiges souvent empreints de problèmes relationnels. Une action en justice est généralement écartée car trop onéreuse par rapport à l'enjeu en causc. Quoi qu'il en soit, il faudra, dans la plupart des cas, vivre encore des années à côté d'un voisin à qui on ne parle plus, dont on se méfie. Alors, pourquoi ne pas tenter la médiation?

Too many people allow themselves to show verbal or physical aggression to persons with whom they have run-ins, with all the uncivil, if not dramatic. consequences that may arise. The police, for their part, do not always have the resources to devote to these disputes, which are frequently colored by personal relationships. A court case is generally out of the question, because it would be too costly for what is at stake in the case. And yet it will be necessary, in the majority of cases, to continue to live for years next to a neighbor with whom one is no longer on speaking terms, and whom one distrusts. So, why not try mediation?

Mediation is also presumably possible, with the consent of both complainant and accused, under CODE DE PROCÉdURE PÉNALE [C. PR. PÉN] art. 41 (Fr.), loi no. 93-2 4 janv. 1993 (establishing that the procureur de la République can, with the parties' agreement, use mediation).

246. For examples, see C. PÉN. (96th ed. Dalloz 1999) (commentary by Yves Mayaud), app., Presse et Communication, 1947, para. 117 (use of letters "SS" after name of minister; "Émule de Barbie," (emulator of Barbie); addition of epithet "crématoire" (crematory) after last name of minister)); id. at 1948, para. 118 ("nazis" or "nazillons"). 
supposed involvement with the Vichy regime or with the Nazis. ${ }^{2.47}$ Where the law of insult still lives, moreover, it retains some of the coloration of old dueling norms, just as it does in Germany: French law still speaks of "affronts to the honor" - "atteintes à l'honneur" - just as German law does. ${ }^{248}$ Some classic dueling insults, such as "blockhead," are still punished in French courts. ${ }^{249}$ Other odd public insults are occasionally punished too.

Moreover, the old law of insults also retains a certain life in French hate-speech legislation. Indeed, such legislation has a sixty-year history in France. For a brief time before the defeat of France by the Nazis, French law included a 1939 hate-speech decree, conceived in a traditional form as covering both defamation and insult. ${ }^{250}$ Military defeat brought repeal of that decree in $1940 ;^{251}$ but today, once again, "racist" speech may indeed be pursued both under the "law" of "public" insulte" and under the "policing" of "nonpublic" insult. ${ }^{253}$ And, as in the case of Germany, this

247. For examples, see C. PÉn. (96th ed. Dalloz 1999) (commentary by Yves Mayaud), at 1934, para. 9.

248. See C. PÉN. art. 29 app. at 1933 (96th ed. Dalloz 1999) (loi du 29 juillet 1881).

249. See C. PÉN. (96th ed. Dalloz 1999) (commentary by Yves Mayaud), at 1948, para. 118 (giving as an example of an insult "buse" or "blockhead"). Numerous other examples are given in the same section.

250. See Law of Apr. 21, 1939, D.P. 1939, IV. 351 (Fr.).

251. See Law of Aug. 27, 1940, D.P. 1940, IV, 254 (Fr.).

252. See C. PÉN. art. 32 app. at 1953 (96th ed. Dalloz 1999) (loi du 20 juillet 1881). The law provides:

La diffamation commise [by any of various means of publication] envers une personne ou un groupe de personnes à raison de leur origine ou de leur apparenance ou de leur non-appartenance à une ethnie, une nation, une race ou une religion déterminte sera punie d'un emprisonnement d'un an et d'une amende de $300000 \mathrm{~F}$ ou de l'une de ces deux peines seulement.

Defamation committed [by any of various means of publication] toward a person or group of persons by reason of their origin or their membership or nonmembership in an ethnic group, nation, race, or particular religion, shall be punished by a term of imprisonment of one year and by a fine of 300,000 franes or by one of these penalties alone.

Id. References merely to "foreigners" in general, however, do not fall under this statute. See commentary, in id. at 1956, para. 18. Compare Loi du 29 juillet 1881, ar. 24 (independent crime of provocation to racial discrimination or hatred):

(Loi $\mathrm{n}^{\circ} 72-546$ du $1^{\text {"a }}$ juillet 1972) Ceux qui, par l'un des moyens énonés à l'aricle 23 [that is, publication by any of various means], auront provoque a la discrimination. 1 la haine ou a la violence à l'égard d'une personne ou d'un groupe de personnes à raison de leur origine ou de leur appartenance ou de leur non-appartenance ì une ethnie, une nation, une race ou une réligion déterminée, seront punis d'un emprisonnement d'un an et d'une amende de $300000 \mathrm{~F}$ ou de l'une de ces deux peines seulement.

Those who, by any of the means described in aricle 23 [that is. publication by any of various means], provoke discrimination, hatred, or violence with regard to a person or group of persons by reason of their origin or their membership or nonmembership in an ethnic group, nation, race, or particular religion, shall be punished by a term of imprisonment of one year and by a fine of 300,000 franes or by one of these penalties alone.

Cf. Douglas-Scott, supra note 10, at 318 (discussing the Gayssot Act).

253. See C. P角. art. R. 625-27 (96th ed. Dalloz 1999): 
French hate-speech legislation must be read in the light of a long historical tradition, reaching back for generations. French jurists remain, indeed, strikingly aware that their law of hate speech is the descendant of an older tradition in the protection of personal honor, now extended to cover even the least of persons, as an example from a textbook suggests:

An important place, among those sentiments to which modern legislation extends the protection of the criminal law, has devolved to honor and personal dignity. Whatever position a human being may occupy in society, however modest the function he may serve, he feels a deep need not to be humiliated, not to be treated with disrespect by those around him.

For a long time, this need was addressed only in the criminal law protecting honorability against defamation and insult, to which the Press Law of July 29, 1881 devoted several provisions. Today the presence, on the soil of our country, of a growing number of foreigners, and the profound alteration of social relations that has given rise, over the last few years, to habits of thought that have been called "racist" or "sexist," have had the effect of provoking, by way of reaction, the appearance of new criminal law, inserted in the law of 1881 and in the Criminal Code, and tending to guarantee the personal dignity of every individual against discriminatory attacks. ${ }^{254}$

La provocation non publique à la discrimination, à la haine ou à la violence à l'égard d'une personne ou d'un groupe de personnes à raison de leur origine ou de leur appartenance ou de leur non-appartenance, vraie ou supposće, à une ethnic, une nation. une race ou une réligion déterminée est punie de l'amende prévue pour les contraventions de la $5^{t}$ classe.

Les personnes coupables de la contravention prévue au présent article encourent également les peines complémentaires suivantes:

1. L'interdiction de détenir ou de porter ... une arme ....

2. La confiscation d'une ou plusieurs armes ....

Nonpublic provocation to discrimination, hatred, or violence with regard to a person or group of persons by reason of their origin or their membership or nonmembership in an ethnic group, nation, race, or particular religion, shall be punished by a fine contemplated for contraventions of the fifth class.

Persons guilty of a contravention contemplated by this article also incur the following complementary penalties:

1. A prohibition on keeping or bearing ... a firearm ....

2. The confiscation of one or several firearms ....

254. VITU, supra note 13 , at 1574.

Parmi les sentiments auxquels le législateur moderne étend la protection du droit pénal. une place importante est dévolue à l'honneur et à la dignité personnelle. Quelle que soit en effet la position qu'il occupe dans le corps social, si modestes qui soient les fonctions qu'il assure, l'être humain ressent profondément le besoin de n'être pas humilié, méprisé par ceux qui l'entourent.

Pendant longtemps, ce besoin n'a été satisfait que par le biais des incriminations protégeant l'honorabilité contre la diffamation et l'injure, auxquelles la loi du 29 juillet 1881 sur la presse a consacré plusieurs dispositions. Or la présence, sur le sol de notre pays, d'un nombre grandissant d'étrangers et la modification profonde des rapports 
In passages like this we see precisely the pattern of leveling up we saw in Germany: French law, too, generalizes old norms of high-status honor as new norms of universal dignity. And again, as in Germany, the consequence is that denigratory racist remarks that carry no penalty in American law can be prosecuted in France. This is true not only of racist defamation but also of racist insult in the narrow sense. "Nonpublic" racial insults, too, are fitted into the traditional jurisprudence-though they are punishable by a fine of up to 10,000 francs, rather than 250 francs, along with a range of other penalties. ${ }^{255}$ As in Germany, too, the "Auschwitz lie" - the denial of the Holocaust-has provoked especially severe criminal responses. $^{256}$

Nevertheless, if the law of insult still lives on in French hate-speech legislation, the vigorous culture of the popular law of insult that so noticeably characterizes German legal life is wholly absent in France. Insult has been defined as not a question of law or rights; and correspondingly, there is no French popular practice of invoking law or rights when one is insulted. Casual empiricism-my conversations with French acquaintances-suggests that most French people do not even know that the law of insult exists, though they do know that it is unlawful (and unwise) to insult a police officer..$^{257}$ A current paperback guide to etiquette makes it clear that the idea that insults might be severe enough to go to law has simply vanished in France, though the memory of dueling has not:

Knowing How To Respond to an Insult

Most etiquette manuals forget this chapter. For a simple reason: It is very difficult to give rules of conduct in this domain. Let us try to tackle the problem with a little more boldness. First of all, what is an insult?

Three centuries ago, insults like "rascal" [bélître] or "skinflint" [fesse-mathieu] were rewarded with sword thrusts. Nowadays, they get a chuckle.

Still, one is sometimes insulted publicly by a testy automobile driver, an unpleasant pedestrian, or a foul-tempered fellow subway passenger... and in terms that hardly vary. The most adroit approach remains to shrug one's shoulders and continue on one's way. After all, you will not cross paths with the insulter again.

sociaux ont fait naitre depuis quelques années de tendances d'esprit qu'on a dites "racistes" ou "sexistes" et qui ont eu pour effel de provoquer. par náaction. l'apparition d'incriminations nouvelles, insérées dans la loi de 1881 et dans le Code pénal, et tendant à garantir la dignité personelle de chacun contre les anteintes discriminatoires. Id.

255. For the full range of penalties, see C. PÉN. ar. 131-12 to 131-18 (96 th ed. Dalloz 1999); and supra note 253 and accompanying text.

256. See, e.g., Douglas-Scott, supra note 10, at 318 .

257. E.g., Conversation with Mme. Isabelle Bahuet, in New York. N.Y. (July 14. 1999). 
Nevertheless, it does happen that the insult is too serious to be treated with disdain. What to do?

The duel is no longer in use, since the beginning of the century ....

The duel no longer being an option today, is it appropriate to settle a dispute with fisticuffs? Nothing is less appropriate! . . .

So what should one do if one is insulted publicly, at a dinner, for example? The best solution is to have enough wit in repartee to ridicule the insulter with a well-put response. ${ }^{258}$

No trace here of the popular German culture of the law. The French way is not a lawsuit, but self-help through repartee. Moreover, even where cases of legal insult do get into court, they never seem odd for the reason that German cases do. Though French jurisprudence continues to speak of honor, it lacks what is so strikingly present in the German-efforts to penalize behavior that seems, to an American, simply rude. The use of $t u$ rather than vous is not a matter for the law in France, or at least not for formal legal regulation. Dire as the social consequences may be of failing to address another person as monsieur or madame, no one imagines that that failure carries legal consequences.

258. HERMINE DE CLERMONT-TONNERRE, POLITESSE OBLIGE: LE SAVOIR-VIVRE AUJOURD'HUI. GUIDE DES BONS USAGES 82-83 (1996). It is well worth quoting the omitted portions of the passage:

Still, one often thinks of the duel that ranged the Marquis of Cuevas against Serge Lifar, the dancer who obsessed him [son danseur fétiche], in the 1930s. Or of the duel between Gaston Deferre, mayor of Marseille, with the Deputy René Ribiere [in the year 1967] .....

$\ldots$

On the other hand, a man who witnesses an insult made to a woman in his presence must not let the affront go unchallenged. From that moment, he finds himself confronted with a frankly ticklish problem: Should he roll up his sleeves and give the insulter a lesson? No. Above all, not in the course of a dinner, where doing so would create a situation impossible to control. Let the affront go without saying anything? That would be to act like a coward. The solution consists in disconcerting one's adversary, as in judo, by pretending to agree with his views, ridiculing him all the Id. while.

On the 1967 duel of Gaston Deferre and René Ribière, the last recorded in France, see BILLACOIS, supra note 104, at 182-83; and NYE, supra note 119, at 216. Madame de ClermontTonnerre errs on the date of the duel between Serge Lifar and the Marquis de Cuevas, which actually took place in 1958. See BILLACOIS, supra note 104, at 185.

For a similar passage dating from 1889, consider Henry Fouquier: "Jadis, les injures amenaient presque toujours des duels; aujourd'hui, elles sont devenues si fréquentes, si disproportionnées avec les faits, qu'on leur oppose souvent, et sans pouvoir être taxé de lâcheté, le plus absolu dédain," quoted in WORMS, supra note 22, at 54. 


\section{NONLEGAL REgULATION IN FRANCE}

It would be a great mistake, though, to conclude from the relative absence of the law in regulating French civility that there is no regulation at all. On the contrary, France is rich in regulation enforeing respect and civility, but it is regulation that takes place in other spheres. It is, in fact, of the first importance to track the regulation of civility into those other spheres. What we find, when we investigate a variety of nonlegal institutions, is that the French law of insult has undergone not death, but a kind of transmigration. The concepts, and the very terminology, of the old law of insult survive. But they survive outside the law as technically defined. In particular, the enforcement of respect goes on in the world of education and everyday manners in ways rich in political meaning.

Here, again, history is the key to understanding the enforcement of respect as we see it in France today. In particular, we must return once again to the history of dueling. Nineteenth-century dueling culture established what has become a general pattern in France: the adoption of legal terminology and legal assumptions in technically nonlegal settings-a striking pattern of the translation of law into lawlike norms. ${ }^{259}$ Thus, early in the nineteenth century, the decline of the technical law of insult was accompanied by the rise of a kind of quasi-legal substitute: the duelist's "code" of behavior. Dueling remained a widespread and widely defended practice in the nineteenth century. Its mores were regulated by an 1836 text, by the Comte de Chatauvillard, whose prescriptions were internationally accepted. ${ }^{260}$ Chatauvillard presented his rules as a law outside the law:

If the code of the duel stands outside the law, if there can be no code but that sanctioned by statute, let us not hesitate, nevertheless, to give that name to the rules imposed by the rules of honor, for the rules of honor are a thing no less sacred than governmental laws. ${ }^{261}$

259. In order to avoid confusion among European readers, I should note that the term "norms" is used differently in American legal writing from the way it is typically used in France especially. "Norms," to an American scholar, are non-legal, whereas in French writing, "norms" refers specifically to legal rules.

260. For a discussion of the general acceptance of the text in France, see NYE, supra note 119, at 137-38; in Germany, see MCALEER, supra note 114, at 46. For the pre-19uh-century tradition, see, for example, SUIIE DE LA CIVILITE FRANCOISE, OU TRATTE DU POINT-D'HONNEUR \& DES RÉGLES POUR CONVERSER \& SE CONDUIRE SAGENENT AVEC LES INCIVILS \& LES FÂCHEUX (Paris, Chez Helie Josset 1676).

261. Chatauvillard, supra note 108, at 5 ("Si le code du Duel est en dehors des lois, s'il ne peut y avoir de code que celui sanctionné par la loi, n'hésitons pas, cependant, à donner ce nom aux règles imposées par l'honneur, car l'honneur n'est pas chose moins sacrée que les lois gouvemementales."). 
It was Chatauvillard who produced the tripartite analysis of "insults" that I quoted above in Part III of this Article. ${ }^{262}$ His nonlegal law of dueling, as I suggested above, became the basis of what is still the law in Germany. In a sense, it became the law in France, too. In a remarkable tale of the interaction of social and legal norms, the French courts of the nineteenth century accepted the validity of Chatauvillard's code, acquitting duelists who had lived up to the demands of Chatauvillard. ${ }^{263}$ Thus, though the duelist's definition of insults was never technically part of the statutory law, it nevertheless became a kind of law in the courts. The courts are not what matter most, though: Presumably, most cases of dueling never found their way there at all. What matters is that Frenchmen who shared the widespread duelists' culture lived according to Chatauvillard. In this way, the extralegal "law" of dueling became a kind of everyday "law" of insult, which survived through the nineteenth century.

Elsewhere too, the old law of insult found new homes away from the courts of law. As the law of insult declined in the nineteenth century, we can trace the rise of rules against insults in the clubs and associations that proliferated in France. The rules of one small 1880 club, for example, managed to pick up all the technical terms of the law of insult:

31. Members of the society must respect each other mutually and make every effort to insure that tranquillity does not cease to reign between them. ....

33. Every name that a member of the society is called, every coarse epithet, every insult [injure] or direct threat to a member of the society or to any other person who has come to a meeting in the company of a member of the society shall be punished by a fine of not less than one franc.

34. Every physical assault [voie de fait] upon a member of the society while in the bosom of the society shall be punished by exclusion from full participation in membership.

35. Exclusion from the society will be pronounced upon any member who is guilty of an affront to the honor of the society or to one of its members [qui aura porté atteinte à l'honneur de la société ou de l'un de ses membres]. ${ }^{264}$

262. See supra note 108 and accompanying text.

263. See NYE, supra note 119 , at 133-35, 140-42, 145-47. Repeated efforts to introduce special legislation on the duel failed in France; unlike German law, French law simply treated dueling as part of the general law of homicide and assault. See id. at 134. Over the course of the 19th century, however, courts made it their practice to acquit "honorable" duclists. See id.

264. RẺGLEMENT DE LA SOCIÉTÉ DE LA RUE-DU-GUÉ, FOUGERÉ 1880, reprinted in JEANLUC MARAIS, LES SOCIÉTÉs D'HOMMES: HISTOIRE D’UNE SOCIABILITÉ DU $18^{8}$ SIËCLE À NOS JOURS 69 (1986). 
Such regulations prohibiting " 'epithets,' verbal 'injuries,' 'menace,' or rude gestures" were extremely common. ${ }^{265}$ Here again we witness the transplantation of the regulation of insult from the courts into lesser social institutions.

The "social" norms of France thus did not simply arise outside the law; they developed by adopting and transmuting the terms and assumptions of the law, making for a characteristically French codification of everyday behavior. We can detect this pattern of adoption and transmutation of the law in the sphere of education as well. Education is, indeed, the most important sphere of all: It is in education, not in the law, that we see the post-Revolutionary French state hardest at work to establish norms of civility. Here, again, we have to look to an old history to understand French practice today. The tradition of associating schooling with the teaching of "good manners" goes back to the sixteenth century in France. As scholars like Jacques Revel and Roger Chartier have shown, the "good manners" that were taught in French schools through most of the early modern period came to be closely associated with aristocratic norms of behavior. ${ }^{266}$ By the latter part of the eighteenth century, though, an Enlightened style of antiaristocratic thought had established itself, one that rejected many of the "artificialities" of aristocratic politesse. When those "artificialities" reasserted themselves in the early nineteenth century, they largely became the possession of a new style of bourgeois life, revolving around a carefully inculcated practice of the outward show of respect. As the republican tradition achieved its slow triumph over the course of the nineteenth century, those old "artificialities," once firmly associated with the royal court, won a place in the newly evolving republican school system.

Indeed, even as the law of insult faded over the course of the nineteenth century, French governmental efforts to inculcate norms of politesse in the schools gathered momentum, and the program of education in the schools,

31. Les sociétaires se doivent respecter mutuellement et faire tous leurs efforts pour que le bon accord ne cesse de régner entre eux. ....

33. Tout surnom donné à un sociétaire, toute épithète grossière, toute injure ou menace directe envers un sociétaire ou toute autre personne venute à la Réunion en compagnie d'un sociétaire seront punis d'une amende qui ne pourra être moindre de un franc.

34. Toute voie de fait envers un sociétaire au sein même de la socićț, sera punic de l'exclusion de plein droit de la société.

35. L'exclusion sera prononcée contre tout sociétaire qui aura porté altcinte à l'honneur de la société ou de l'un de ses membres.

265. NYE, supra note 119 , at $130-32$.

266. See Roger Chartier, Lectures et lecteurs daNS La France d ANCien Regime 45-86 (1987); Jacques Revel, The Uses of Civility, in A HISTORY OF PRIVATE LIFE 167-20S (Roger Chartier ed. \& Arthur Goldhammer trans., 1989). On the formative importance of carly modern civility manuals in the making of French education, see also MAURICE CRUBELLIER. L'ECOLE RÉPUBLICAINE, 1870-1940, at 78-84 (1993). 
especially toward the end of the nineteenth century, always included an emphasis on training in norms of politeness. The strongly republican government that took charge of France in $1880^{267}$ was responsible, not only for the liberal 1881 law on freedom of the press, but also for the 1881 law on compulsory primary education. That law was intended to substitute "moral and civic" education for religion in the schools, ${ }^{268}$ in practice, this turned out to mean, in large part, teaching good manners-both rules of decency and rules of civility. As one of the founding fathers of French republican primary education described it in 1880 , pupils learned both good manners and the classically Cartesian style of French reasoning: "on the one hand, habits of personal cleanliness, order, self-respect, justice, and mutual benevolence; on the other, habits of lucid, clear, precise thinking, and well-considered and firm judgment." 269

The program of inculcating good manners was particularly important in the countryside, as part of the effort to transform, in Eugen Weber's famous phrase, "peasants into Frenchmen." The republican school was supposed

to improve manners and customs, and soothe the savage breast. The polite forms that were inculcated "softened the savagery and harshness natural to peasants." ... Schools set out to "modify the habit of bodily hygiene and cleanliness, social and domestic manners, and the way of looking at things and judging them." Savage children were taught new manners: how to greet strangers, how to knock on doors, how to behave in decent company. ${ }^{270}$

It is not surprising that, in the teaching in these republican schools, we can discover the same phenomenon we find in private associations: the transmigration of the vocabulary of the law. Thus, the 1891 "morals" curriculum for the elementary schools of one French département aimed to inculcate the basics of the law-including the law of insult as well as of dueling. In their third trimester, pupils were to learn:

1. Application and development of the idea of justice. Justice is absolute, without exception. It obliges us:

267. See generally KATHERINE AUSPITZ, THE RADICAL BOURGEOISIE: THE LIGUE D'ENSEIGNEMENT AND THE ORIGINS OF THE THIRD REPUBLIC (1982).

268. For the growth of the ideal of moral education out of the older civility literature, see the elegant treatment by FRANÇOIS JACQUET-FRANCILLON. NAISSANCES DE L'ECOLE DU PEUPLE. 1815-1870, at 248-57, 250-52 (1995) ("De civiliser à moraliser").

269. F. PÉCAut, L'EduCATION PUBLIQUE ET LA VIE NATIONALE 5 (Paris, Librairic Hachette 1897) (" d'une parte, des habitudes de propreté corporelle, d'ordre, de respect de soi, de justice, de bienveillance mutuelle; et de l'autre, des habitudes de pensée lucide, claire, précise, de droit et ferme jugement"). On Pécaut as a founding father, see CRUBELLIER, supra note 266, at 77.

270. Eugen Weber, PEASANTS into Frenchmen: THE Modernization of Rural FRANCE, 1870-1914, at 329-30 (1976). 
(a) To respect human life. Homicide, legitimate defense (death penalty), duelling.

(b) To respect human freedom. Inviolability of the person; freedom, a condition of morality; slavery (slave trade), serfdom.

(c) To respect property. Property is sacred; it is a right founded on individual freedom and work. Theft (various kinds: fraud, poaching, etc.). Donation and transmission of property, inheritance.

(d) To respect the honor and reputation of others. Calumny, defamation, ill-gossip, insult, indiscretion, envy, ingratitude are counter to the idea of justice. Benevolence towards others. What is meant by public opinion.

(e) To respect the given word (see above, under Soul) $\ldots{ }^{271}$

The law of insult may have been demoted to a mere "police" offense in the criminal code, but in the schools of the département of the Somme, it stood ranged in full glory alongside the law of property, the law of homicide, and all the rest.

Why this emphasis on teaching good manners? As Weber's argument suggests, the republican government lavished such attention on the teaching of politesse because generalizing politesse served the purpose of integrating all Frenchmen, rural and urban, into a single republican culture. Teaching everybody correct manners was necessary, as leading educators of the Third Republic stressed, for the making of a true social democracy: Teaching politeness meant teaching respect for others, and so teaching all Frenchmen to behave respectfully was part of creating a society founded not on honor but on human dignity-a society in which everyone was entitled to respect. Schools were to inculcate "the dignity of the person in every human being, true foundation of democracy and of free institutions, from which flows self-respect, and the respect for others, for women, and for children." 27 After all, the Republican ideal ran, "the little Frenchman has the privilege of belonging to the nation that was the first to proclaim before the face of the world the rights of man and the citizen," and his "moral and civic" education was to educate him accordingly. ${ }^{273}$ Universal politesse meant universal membership in a society of dignity for all.

271. Department of the Somme, Morals Curriculum 1891 (Aug. 1, 1891), in PHYLLS STOCKMORTON, MORAL EDUCATION FOR A SECULAR SOCIETY 184 (1988). For the idea of using education to combat crime, see JACQUET-FRANCILLON, supra note 268, at 255-57.

272. PÉCAUT, supra note 269 , at $x$.

273. CRUBELLIER, supra note 266, at 86 (“ (L]e petit Français a le privilìge d'appartenir a la nation qui, la première, a proclamé à la face du monde les droits de l"homme el du citojen."). 
This tendency survives in French education down to this day. ${ }^{274}$ The official prescription for teaching in the French schools-which are of course still subject to tight national control-still includes teaching the "rules of politesse." ${ }^{275}$ This is not entirely easy to interpret, of course: Every Western school system includes some form of training in "good manners." Nevertheless, the teaching of "rules" of politeness in the French schools sits very comfortably with a larger French tendency - the tendency to speak, as so often in quasi-legal terms, of codes of politeness in everyday life, to understand politesse as a set of ordered and learnable norms. For that reason it seems not unreasonable to guess that the teaching of those rules is more seriously meant and more formative in France than in a country like the United States.

For indeed, the tendency to speak of codes of politesse, just as one once spoke of the code of the duel, is remarkably widespread in France. ${ }^{276}$ Here at last we pass beyond formally stated institutional rules to consider what undoubtedly matters most for the maintenance of French civility: social enforcement. The observation that formalized courtesy plays a peculiarly

274. A recent memoir of a French upbringing still touches all the 19th-century republican chords. Learning fine French manners means learning to be a lover of all mankind in a distinctly courtly way:

Un gentleman est courtois, un Français plus encore: il est en outre beau parleur, subtil et humoriste, son esprit est orné comme le sont sa livrée et ses gestes. Accueillir ses invités, s'entretenir avec eux: tel est l'usage de la vie, une sociabilité faite d'intérêt pour les autres et pour les questions fondamentales .... Nous avons appris à nous intéresser à notre prochain, à l'écouter et à le mettre en valeur. Elever un enfant, c'est l'introduire dans le monde magnifique de l'humanité. L'éducation consiste à apprendre la beauté morale.

A gentleman is courteous, a Frenchman even more so: What is more, he speaks beautifully, subtly, and humorously; he has an elegantly omamented wit, just as he has elegantly ornamented dress and elegantly ornamented gestures. To welcome his guests, to converse with them: This is how life is lived, with a sociability founded in the practice of taking an interest both in other persons and in fundamental questions [of philosophy and the like].... We have learned to take an interest in our neighbor, to listen to him, and to value him. To raise a child is to introduce him to the magnificent world of humanity. Education consists in learning moral beauty.

ODILE MARCEL, UNE ÉDUCATION FRANÇAISE 35 (1984).

275. See Ministère de l'éducation nationale, de la recherche et de la technologic, Programmes de l'école primaire, Cycle des approfondissements (visited Dec. 3, 1999) <http://www.education. gouv.fr/prim/progec/inextens/acitoyen.htm>.

276. One 19th-century author could even call his guide to politesse the "Code Civil." Se' Horce A. Raisson, CODE CIVIL. MANuEl COMPLET DE la POLITESSE, DU TON, des MANIEKHS DE LA BONNE COMPAGNIE (Paris, B. Renault 14th ed. 1853), cited in NYE, supra note 119, at 267 n.11. Raisson, it should be noted, called almost every one of his many books a "code." For an interesting early example of the French law-ification of honor, see DISCOURS DE MORALE, SUR L'HONNEUR, L'OPINION, LES DEVOIRS, LES PASSIONS, LE BONHEUR \& les PlaisiRs, \&C., ADRESSÉS À UN JEUNE SEIGNEUR 5 (Cambridge, Chez de Senne 1788): "L'honneur consiste dans la constante habitude, \& l'inébranlable volonté de faire le bien selon sa charge \& ses moyens." This echoes the famous definition of the law in DIG. 1.1.10 (Ulpian. libro primo regularum), "Justice is the constant and unwavering determination to give unto each his due." "Codes" of politesse were preceded by "codes" of dueling conduct. On the importation of these from Italy. see NYE, supra note 119 , at 25. 
important roie in the organization of French society is, of course, a commonplace. ${ }^{277}$ Foreigners often speak of this aspect of France: "The polite tradition is considered a rampart of French civilization, a code of behavior that makes life in society possible." ${ }^{278}$ Foreigners also often note that French politesse is thought of as peculiarly artificial, just as its critics used to say in the late eighteenth century: "The whole of society rests on a bogus politeness, on courtesies that no one practises except to mask their real thoughts." 279 To outsiders, France seems a society of appearances, a place where the outward show of respect dominates to a strange excess. French authors, for their part, also frequently note the centrality of politesse in French society, although rather than emphasizing its "artificiality," they often like to focus on its "codified" character. As Proust, the most elegant witness, described it, the "code" of good behavior had a "jurisprudence," a body of case law. ${ }^{280}$ This "[p]oliteness" is, as another French author puts it, "the cornerstone of bourgeois behaviour .... How one greets people, how one introduces oneself, how one says thank you, and how one expresses feelings form a cultural concentrate that balances proximity against the distance that must be maintained in relation to other people." 281 It is, I think, in this widespread social commitment to the codes of politeness that we really come to the heartland of the French culture of civility.

For the French do have a culture of civility. This is something that deserves to be emphasized, since Americans often perceive the French to be rude. No surprise: Americans in France bring a species of what seems like rudeness down upon themselves. French codes of civility require outward shows of respect that Americans typically, and egregiously, neglect. American tourists frequently charge into French encounters without offering even the minimally polite formulas that educated French persons expect-without even beginning by saying, "Bonjour, Madame" or "Bonjour, Monsieur." Inevitably, such Americans are perceived as rude; inevitably, they are snubbed in response. On a deeper level, perhaps, Americans take offense at the very toleration for "artificiality" that lies at the heart of French politesse; the French practice of artificiality does not sit well with an American taste for authenticity. All of this opens a gulf of

277. On its formality, see W.L. WILEY. THE FORMAL FRENCH (1967).

278. SANCHE DE GRAMONT. THE FRENCH: PORTRAIT OF A PEOPLE 305 (1969).

279. THEODORE ZELDIN, THE FRENCH 55 (1983): cf. GRAMONT, supra nole 278, at 305 ("Politeness in the French sense is not natural but contrived. It is preciscly because it is antificial that it is recognized as a mark of special attention. It is, as Montesquicu remarked, an embellishment.").

280. MARCEL PROUST, LE Cóté DE GUERMaNTES II (Thierry Lager \& Brian Rogers eds.), in 2 A LA RECHERCHE DU TEMPS PERDU 882 (Jean-Yves Tadié ed.. Gallimard 1988) (1922) ("IE]lle ne voyait rien dans le code des convenances que lui indiquât la jurisprudence à suivre ....").

281. BÉATRIX LE WITA, FrenCH Bourgeols Culture 81 (J.A. Underwood trans., Cambridge Univ. Press 1994) (1988). 
cultural incomprehension that leaves Americans too little aware of the strength of the French culture of civility.

Yet that culture of civility is strong; and it is, once again, full of the memory of an aristocratic past. Such has indeed been the burden of some of the most widely discussed, and (for the most part) ${ }^{282}$ well-received sociological writing on France of the last decades, including Norbert Elias's Civilizing Process ${ }^{283}$ and Pierre Bourdieu's Distinction ${ }^{284}$ Both authors, and many others as well, ${ }^{285}$ emphasize the same point: The culture of politesse that is such a marked feature of French social life is an historically aristocratic culture that has been generalized throughout French society. As Elias classically put it: " $[\mathrm{B}]$ ourgeois society, in everything that concerns social conduct, [has taken] over the ritual of courtly society without developing it with the same intensity." ${ }^{286}$ The sense of this courtly background to everyday interaction is so powerful that when French witnesses describe the French pattern of courtesy, they are rarely satisfied with the observation that politesse is highly codified. They generally find it important to add observations about the history of social conflict in France: Politesse is associated, in French commentary, with the old French aristocracy; and the wide extension of patterns of politesse is associated

282. Important doubts are raised about Elias's argument in DANIEL GORDON, CITIZENS WITHOUT SOVEREIGNTY: EQUALITY AND SOCIABILITY IN FRENCH THOUGHT, 1670-1789, at 8691 (1994); and EMMANUEl LE ROY LADURIE. SAINT-SIMON app. (1997). Gordon questions whether courtly forms of politeness were really the only ones at large in French carly modern culture, and takes particular pains to emphasize the egalitarian coloration of salon interaction already present in the 17th century, see GORDON, supra, at 93, and certainly in the 18th century. See also JeROEN DUINDAM, MYTHS OF POWER (Lorri S. Granger \& Gerard T. Moran trans., 1994) (attacking Elias's picture of court society).

Gordon's argument is fundamentally incompatible with my own, and it is important to say a word about it. The strength of at least a narrow version of Elias's claim-a version holding that there was a generalization of aristocratic values in the late 18th and 19th centuries-is. I think. clear on the strictly legal-historical evidence I offer here. Within the history of the law of insult. there is no escaping the aristocratic heritage. This is, however, only a point about law; it says nothing about the more elusive and complex social practices that are Gordon's subject.

At the same time, I agree entirely with Gordon's claim that the forms of civility are not necessarily hierarchical-not even, as Duindam has argued, in monarchical courts. On the contrary, as I argue infra text accompanying note 363 , civil interaction is often egalitarian. As I also argue below, however, a hierarchical image of society does belong to the Vorverstindinis underlying even egalitarian relations; and to that degree, something like Elias's claim makes sense.

283. EliAS, supra note 24.

284. Pierre Bourdieu, Distinction: A Social Critique of the Judgement of TASte (Richard Nice trans., Harvard Univ. Press 1984) (1979).

285. See, e.g., NYE, supra note 119, at 8 (" [A] male code of honor... survived the destruction of the Old Regime in 1789 by accommodating its practices and usages to the unique sociability and legal arrangements of bourgeois civilization .... [A] code that sustained a military and landowning race (the term used by nobles themselves) ... appeal[ed] to their bourgeois successors ...."); see also MARCEL, supra note 274, at 145 n. B ("[L]a bourgeoisie ... n'existe pas comme telle et ne peut surgir financièrement, socialement et économiquement qu'en s'identifiant à l'ancienne noblesse ....").

286. ElIAS, supra note 24, at 504. 
with a peculiar pattern of French egalitarianism that has extended historically aristocratic styles of behavior throughout society. ${ }^{287}$

To speak of this "egalitarianism" is not to say, to be sure, that there is no sense of social hierarchy left in French politesse. Quite the contrary: Like the German law of insult, the French social regulation of civility is strongly oriented toward rank and respect. Here, for example, is how one French author describes the Franco-American contrast in one of the aspects of French politesse that is most baffling to foreigners, the salutation in letters:

When a correspondent writes me from the United States, his letter ends with the one-size-fits-all formula used in Oregon as well as in New England: "Sincerely yours." Sincerely what, I ask you. But no matter! The Americans have always had a flair for not getting tied up in knots over the forms of aristocratic society, which they have never known.

By contrast, like all of my compatriots, at the end of every letter I am led to a self-interrogation. Should I write: "Veuillez, Monsieur, recevoir l'expression de mes sentiments distingués" ["Be so kind, Sir, as to receive the expression of my distinguished sentiments"]? Shouldn't my sentiments, in this instance, really be "respectful"? Should I write "recevez" [ordinary form of "receive"] or "agréez" [elevated form of "receive"]? Would it be appropriate that I speak of my "consideration," and should my consideration declare itself to be "high" or merely "distinguished"? And the "compliments"? And the "sentiments empressés" ["fervent sentiments"]? You have to wrack your brain over the adjective "devoted," dip your pen ten times in addressing a woman, a colonel, an archbishop. All of this has been coded [codé]; one must absolutely not lose one's bearings, and the democratic professor that I believe myself to be is always astounded when one of his students offers him his "cordial thoughts." 288

As this passage suggests, the norms of politesse that are so central in French life, and that foreigners absorb only after occasionally painful struggles in everyday interaction, by and large call for a show of differential

287. For a rich collection of examples, tracing a wide range of aspects of current French politesse to their old regime routes, see Well, supra note 218 . For a 19th-century example, see NYE, supra note 119, at 166 (" [O]ur bourgeois fin-de-siècle cedes nothing 10 old regime nobles in courtesy, correctness, and probity." (quoting Daniel Cloutier)).

288. MICHEL WINOCK, PARLEZ-MOI DE LA FRANCE 84 (1995). For a guide to closing salutations, graduated according to the "distance" between the comespondents, see WHO'S WHO IN FRANCE 1993-1994, at 1801 (1994). 
respect for other persons. ${ }^{289}$ (It goes without saying, once again, that they also involve certain highly effective methods of cutting and snubbing: being polite and being pleasant are not the same thing.)

Nevertheless, the French tendency to generalize respect throughout the population is powerful. The French emphasis on maintaining a high level of respect at all times is particularly marked in the practice of forms of address. French persons remain, despite changing mores, ${ }^{290}$ much slower than persons of almost any other European nationality to use the "thou" form, maintaining the formal "you" even with persons they know quite well. This practice of showing a sort of stiff equal respect to everybody is, in the eyes both of the French and of observant foreigners, a decidedly republican practice. Stefan Zweig, for example, made a point of emphasizing the egalitarianism of French courtesy:

Once, when I was in an elegant restaurant-it was Larue, near the Madeleine-in came some rich farmers from Normandy, who had been to a baptism; they thundered in in heavy shoes that beat the floor like horsehooves, in village costumes, their hair so thick with pomade you could smell it in the kitchen. They talked loud, and got louder the more they drank, and merrily slapped their fat wives on the thighs without a moment's embarrassment. It didn't bother them in the least to be honest-to-god country people sitting between white dinner jackets and elegant make-up jobs, but even the waiter, shaven smooth as a mirror, didn't turn up his nose, as he would have done with such bumpkin guests in Germany or in England. He served them with the same politeness and irreproachability that he served the ministers and excellencies, and it even gave the Maître d' pleasure to offer a particularly hearty welcome to these fractious guests. Paris was a place where there was simply a coexistence of contraries, not a higher and a lower .... ${ }^{291}$

The same point is to be found in French commentators: As one author of a guide of politesse put it in 1821, "All men should be equal before $l a$ politesse as they are before the law." 292 Others said similar things in the nineteenth century as well. ${ }^{293}$ Contemporary etiquette books continue to

289. Of course, it has to be said that "showing respect for other persons" is not a selfexplanatory phrase; in fact, some of them are ways of showing respect that are pecular to French practice.

290. On these, see WEIL, supra note 218 , at 70-71.

291. STEFAN ZWEIG, Die Welt VON GeStern: ERINNERUNGen EINES EUROPAERS 125 (1955).

292. NYE, supra note 119, at 129 (quoting LOUIS-DAMIEN EMERIC, NOUVEAU GUIIDE DE LA POLITESSE 23 (Paris, Roret \& Roussel 1821)).

293. As another, more cynical, French author-or at least, one more conscious of the artificialities of the outward show of respect-wrote in 1837, "La politesse is the simulacrum of love for one's neighbor; it is a tacit truce between men consumed by self-love, the silence of egotism, an involuntary respect for human dignity. It has been invented to re-establish in this 
speak in exactly the same terms. ${ }^{294}$ It remains an ideal of French politesse, if only an aspirational one, that all persons should be able to act like Zweig's LaRue Maître d', treating all with an irreproachable equality.

What we thus see in the French case, taken all in all, is much the pattern of leveling up that we saw in the German law of insult, though principally on the social rather than the legal plane. Reaching back into the seventeenth century, and perhaps further, a style of courteous behavior that had been the characteristic of a courtly culture was gradually diffused throughout French society. Everyone who masters the "artificialities" of French politesse has thus become, to a certain extent, a participant in aristocratic society. The story is not just a social one, though; it is important to emphasize that it has both legal and political aspects as well. The law mattered in the formation of French politesse, for the "code" of French norms was at least partly formed on the template of the law. As for politics, the French state, especially through the educational system, has made the general extension of courteous forms a central element in the republican ethos since the nineteenth century. More broadly, there is a kind of republicanism in French politesse whose importance should not be minimized. The fact that everybody can expect to be called vous has something to do with the kind of republic that France is.

world the appearance of equality." Id. (quoting I EDOUARD ALLETL DE LA DEMOCRATIE NOUVELLE. OU DES MOEURS ET DE LA PUISSANCE DES CLASSES MOYENNES EN FRANCE 107 (Paris, F. Lequieu 1837)). For another example, see id. at 155 (quoting JEAN MACE. LES VERTUS DU RÉPUBLICAIN (n.p. 1848)) (“[P]ositive law is never exhaustive and politesse must make up for the gaps in the code ... [supplying] fraternal love .... reciprocal cgalitarianism .... universal suffrage.").

As Heinrich Heine put it, the goal of the French Revolution was to abolish bourgeois inequality and to substitute aristocratic equality for all. See HEJNRICH HENE. ENGLSCHE FRAGMENTE (1828), reprinted in REISEBILDER 499 (1993) ("[W]enn die Canaille roturière sich die Freiheit nahm, jene hohe Noblesse zu köpfen, so geschah dieses vielleicht weniger um ihre Güter als um ihre Ahnen zu erben, und stat der bürgerlichen Ungleichheit cine adlige Gleichheit einzufuihren.").

294. See, e.g., SABINE DeNuelle, LE SAVOIR-VIVRE: Guide des REgles et des USAGes D'AUJOURD'HUI 9 (1999):

À la politesse des apparences-tenue, aisance. maintien. gestes-se juge le degró de culture et d'éducation de quelqu'un, indépendamment de son rang social et de son niveau de fortune; les coutumes peuvent varier d'une région ou d'une classe sociale a l'autre, mais la délicatesse de la personne et l'aisance des manières ne connaissent pas de frontières.

A person's degree of culture and education is judged by the politesse of appearancesphysical bearing, ease and assurance of manner. gestures-independently of that person's social rank and level of fortune; dress may vary from one region or social class to another, but the délicaresse of a person and the ease of manners know no borders. 


\section{THE AMERICAN CASE}

Clearly enough, there is much in these societies that sets them apart from the American republic. Before trying to analyze the differences among French, German, and American societies, though, it is important to sketch, if only rapidly, the state of American civility and American law.

A word of methodological caution first. My goal in this Part is to show that the United States displays a relative lack of civility, both in its social practices and in its law. Showing such relative differences is the great strength of comparative law; showing such differences does not, of course, imply that the United States has any absolute lack of civility. To readers to whose minds exceptions spring, let me therefore emphasize: This is a comparative study!

Seen in comparative perspective, then, the lack of civility in the United States-at least outside the American South-is as proverbial as the presence of civility in France. The very intensity of the pro-civility campaign suggests that American society displays fewer of the forms of respectful interaction than do French and German societies. And indeed, just that has been said about American society for many generations. Norms of politesse are much less generally shared and idealized among Americans than among French, at least outside the American South and some nonurban areas. Everyday interaction in the United States has long had a more freeform character, patterns of deference having begun to vanish noticeably by the late eighteenth century. ${ }^{295}$ "Excess of ceremony," Noah Webster already instructed schoolchildren in 1789, "shews want of breeding. That civility is best which excludes all superfluous formality." ${ }^{296}$ Americans know how strongly this attitude has survived into the present. Forms of address vary considerably, and the use of first names, often regarded as an English-language equivalent of the "thou" form, is common. ${ }^{297}$ This tendency is one part of a larger phenomenon that has evocatively been called "pseudo-Gemeinschaft"; 298 European visitors have long observed that American interaction is characterized by a kind of obligatory camaraderie that non-Americans experience as a deliberate general rejection of norms of politesse-and that Europeans can experience as

295. See the survey of developments in CMIEL, supra note 9, at 40-45. For the growing informality even in the prescriptions of American etiquette books since World War I, see ARTHUR M. SCHLESINGER, LEARNING How To BeHAVE: A Historical STUdy or AMERICAN ETIQUETTE BOOKS 49-61 (1946).

296. Webster's advice is quoted and discussed in CMIEL, supra note 9, at 45 . For the antiaristocratic bent of Webster, see also id. at 52-53.

297. On the use of first names, and on slang undercutting hierarchy generally, sec $i d$. at 128 29.

298. ERving Goffman, The Presentation of SElf in Ever yday Life 50 (1973). 
"barbarism," in Robert Wiebe's phrase. ${ }^{299}$ As one French visitor to the United States said of an 1864 political rally, it was a

"strange scene," far removed from French rural gatherings "where some elegant gentleman addresses our worthy peasants in that dignified ... style" or even from meetings of the French proletariat where "decency" and "civilized manners" ruled more often than not.... "These people [the Americans] deal and wish to deal only with their equals; one has to speak their language, to be even more vulgar than they are." 300

Arthur Schlesinger thought that this American pattern should be traced to the social origins of our first settlers in "the peasant and working classes." ${ }^{301}$ It is certainly possible to quarrel with Schlesinger's book on various counts, but it is true that our civility culture looks like a thing of peasants in contrast to that of France. No generalization of aristocratic norms to the lower orders here has taken place; if anything, as Kenneth Cmiel has shown in his book Democratic Eloquence, American culture has put pressure on everyone operating in the public sphere to dumb it down, to talk on the lowest social level.

To be sure, the tale is not one of wholly unmixed "barbarism." The United States belongs, in some limited ways, to the same Western tradition as do Germany and France. It is true, for example, that dueling, and its associated cult of honor, existed for a very long time in the American South. ${ }^{302}$ During the early Republic, it existed in the North as well. ${ }^{303}$ Particularly in colonial Virginia, there was a culture of politeness that could

299. WIEBE, supra note 9, at 47-54.

300. CMIEL, supra note 9, at 72 (quoting and discussing Emest Duvergier de Hauranne).

301. SCHLESINGER, supra note 295, at 1 .

302. See Edward L. Ayers, Vengeance and Justice: Crime and PUNiShMeNt IN the 19TH-CENTURY AMERICAN SOUTH 9-33 (1984); KENNETH S. GREENBERG. HONOR AND SLAVERY 4-23 (1996); WYATT-BROWN, supra note 39, at 350-61. For colonial Virginian ideas of honor, see GREENBERG, supra, at 96-97. For the aristocratic origins of much of Virginia's elite, See DAVID HACKETT FISCHER, ALBION'S SEED: FOUR BRITISH FOLKWAYS IN AMIERICA 212-16 (1989). For the origins of Massachusetts setulers in the "sturdy middle class of England," sec $i d$. at 27. For William Penn's doubts about the value of dueling, see id. at 458 . For endemic violence in colonial backcountry, see id. at 765-71. The reluctance to go to law was there as well. Compare the advice given to Andrew Jackson by his mother: "Always setlle them cases yourself." quoted in id. at 765. Cf. GREENBERG, supra, at 21-22 (describing eyewitness accounts of Jackson's defenses of his honor against insult). Nevertheless. Americans have tended to describe their variety of the duel itself as an egalitarian institution: "We are all parvenus. pretenders or snobs." WYATT-BROWN, supra note 39, at 355 (quoting William J. Grayson).

303. See AYERS, supra note 302, at 19-20, 23-24; WYATT-BROWN, supra note 39, at xv (discussing persistence of honor norms in early-19th-century New England); Joanne Barrie Freeman, Affairs of Honor: Political Combat and Political Character in the Early Republic $11 \mathrm{n} .16$ (1998) (unpublished Ph.D. dissertation. University of Virginia) (on file with The Yale Law Journal). For social rules of deference that hung on in Massachusents into the carly 19th century, see FISCHER, supra note 302, at 180 . For a discussion of deference education in colonial Virginia. see id. at 314-16, 321-22; WYATT-BROWN, supra note 39, at 161-62. 
look very European: The young George Washington wrote a book of Rules of Civility and Decent Behavior for himself that advised emulating "persons of quality" and not the "vulgar." 304 The first Federalist presidencies had an often-remarked air of the aristocratic about them. ${ }^{305}$ Styles of a kind of "aristocratic" decorum dominated American language until the mid-nineteenth century as well. ${ }^{306}$ Into the present, moreover, a "culture of honor" has survived in the American South, as Richard Nisbett and Dov Cohen have argued in a remarkable recent study. ${ }^{307}$ In fact, Nisbett and Cohen document both psychological and physiological responses to insults among Southerners-physiological responses that include such markers as increased testosterone levels. ${ }^{308}$ Insults clearly play something like the social role in the South that they play in the honor culture of Germany-though with an important difference: Southern insults lead to high rates of violence that we do not see in German society. Within the present-day African-American subculture, too, there is literature identifying a strong. and often violent, propensity to react to insults. ${ }^{309}$ Honor culture is thus not entirely absent in the United States.

Indeed, our tradition has even included a certain measure of the same law that we find in Germany and France. Thus, many American states passed insult and anti-dueling statutes in the nineteenth century, ${ }^{310}$ and three Southern states still have dueling statutes on the books. ${ }^{311}$ Within the common law, too, there are remains of the age of dueling to be found, in the

304. See CMIEL, supra note 9 , at 28.

305. On this aristocratic air and the conflicts over it, see Freeman, supra note 303, at 24-73.

306. See CMIEL, supra note 9, at 14 ("By the mid-nineteenth century ... the very decorum that 'gentlemen of the old school' saw as essential to principled behavior was viewed by large segments of the democratic public as 'aristocratic."'); id. at 57, 91-92, 202-03.

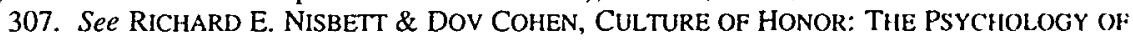
VIOLENCE IN THE SOUTH (1996).

308. Sec id. at 41-55.

309. See Eluah Anderson, THE Code of the Street: DeCEncy, Violence ANd the MORAL LIFE OF THE INNER CITY 66-106 (1999).

310. For anti-dueling statutes, see ALA. DIG. LAwS 134 (D. Woodruff 1836); 2 CONN. DiG. LAws 334 (Durrie \& Peck 1823); N.J. PUB. LAwS 237 (Josiah Harrison 1833); 2 N.Y. RkV. STAT. pt. IV, chap. 1, tit. 1, \$6 (Packard \& Van Benthugsen 1829): 1 OHIO STAT. 441 (Corey \& Fairbank 1833); and PA. DIG. LAwS 334 (James Kay, Jr. \& Bro. 1852). For a discussion of the high rates of defamation suits in the early years of the settlement of British North America, sec WYATT-BROWN, supra note 39, at 447.

On Georgia's repeal of its dueling statute, see also 22 AM. JUR. 468 (1834); and Livingston's Draft Code of Offences and Punishments for Louisiana, tit. 19, ch. 6, p. 133 (B. Levy \& Co. 1822). For Mittermaier's rejection of the American practice of rendering duelists incligible for public office, as an unacceptable defaming punishment, see MITTERMAIER, BEITRAGE ZUR LEHRE: VOM DUELL, ARCHIV DES CRIMINALRECHTS 379 n.f. (n.p. 1834).

311. These are Mississippi, Virginia, and West Virginia. For these statutes and their "origin as part of an anti-dueling code," see W. PAGE KEETON ET AL., PROSSER AND KEETON ON Tilt: LAW OF TORTS $\$ 12$, at 60 (5th ed. 1984). See also FLYNN, supra note 26, at 76-79 (noting cases of the heightened sensitivity of Southern courts to insults as justifying violent acts as late as the 1930s, and especially the persistence of the Texas "paramour" law, which until 1971 treated a husband's murder of his wife's lover, if caught flagrante delicto, as justified). For dueling and honor, see Post, supra note 7, at 704-05. 
doctrine of assault and battery. The familiar tort-law principle that any "touching" may qualify as a battery sounds a lot like the old German and French doctrines of the Tätlichkeit and the voie de fait; touchiness, as it were, is characteristic of the duelist's ethos. As the standard dueling manual of the nineteenth century put it, "Quiconque touche, frappe" - "To touch a person is to hit him." 312 It is unsurprising, then, that the common-law doctrine of battery dates precisely to the late seventeenth and early eighteenth centuries-the high era of early modern dueling. ${ }^{313}$ This doctrine made its way into the United States too, in a period when dueling was still common, as the earliest American case on the doctrine of battery makes clear. ${ }^{314}$ It hangs on today, an odd relic of an aristocratic age.

Moreover, if there are traces of an aristocratic tradition within American law, there are traces of what we can think of as an antiaristocratic tradition too. Some historically low-status populations in the United States-especially racial minorities, most especially African Americansdisplay, of course, a strong sense that America is a place with a history of social hierarchy. That sense is close in spirit to the sense of historic social hierarchy that helps shape legal culture in Germany and France. It is accordingly no surprise if among commentators on race matters we find the most determined insistence on the need for hate-speech legislation: Many African-American authors show something akin to the European sense that, after centuries of distinctions in dignity, honor ought now somehow be generalized throughout the population. The same is true of at least some commentators on the place of women in American society, who have also tried to grasp at whatever there is in the American legal tradition that would permit the construction of a law of generalized dignity.

Yet all this does not make the United States European. Those who would like to see a law of generalized dignity here have not found much to grasp; for the fact is that our dominant legal tradition has developed in a

312. CHATAUVILLARD, supra note 108 , at 9.

313. For the early history (though without reference to the culture of dueling) see 8 W.S. HOLDSWORTH, A HISTORY OF ENGLISH LAW 422-23 (1922), which traces the shift from a medieval concept of battery as "the infliction of physical injury" to the modern concept of a touching importing an insult; and FREDERICK POLLOCK. THE LAW OF TORTS 218-19 (13th ed. 1929). The leading statement of the modern rule is Cole v. Tumer, 6 Mod. 149 (Q.B. 1705) (Holt. C.J.) ("[T]he least touching of another in anger is a battery."). See also Regina v. Cotesworth, 6 Mod. 172 (Q.B. 1705) (Holt, C.J.) (holding that spitting is a battery).

314. The Supreme Court of Pennsylvania stated.

As to the assault, this is, perhaps, one of that kind, in which the insult is more to be considered, than the actual damage; for, though no great bodily pain is suffered by a blow on the palm of the hand, or the skir of the coat, yet these are clearly within the legal d[e]finition of Assault and Battery, and among gendemen. 100 often induce duelling, and terminate in murder.

Respublica v. De Longchamps, 1 U.S. (I Dall.) 111, 114 (Pa. 1784) (McKean, CJ.). For continuing citation of this case, see 1 THOMAS ATKINS STREET. THE FOUNDATIONS OF LEGAL LIABILITY 6 (1906). 
way that sets it sharply apart from the dominant traditions of Continental Europe. If we have our bit of quasi-aristocratic tradition lying somewhere in our past, the fact is that honor has, effectively, not survived as a cognizable value in our law. Thus, the early American tradition of dueling and insult law never evolved into anything like the German law of insult, or even the French law of insult. Even in the American South, the law has comparatively little to say about rude behavior. ${ }^{315}$ There is, to be sure, some criminal law of "abusive language" in the United States. This law differs from what we see in Europe, though. First and foremost, the American law of abusive language is a law of fighting words, both by its own terms and under the limitations of First Amendment jurisprudence. A mere show of disrespect, without an immediate threat of violent breach of the peace, is not punishable in the United States. ${ }^{316}$ Moreover, and strikingly, the American criminal law of abusive language focuses heavily on the use of obscenities. ${ }^{317}$ In this regard, the American law of abusive language often looks more like a law of decency than a law of civility. ${ }^{318}$ (Indeed, in other respects too, the United States has more law of decency than France and Germany do; we are, for example, much more resistant to public nudity than either of those countries. Perhaps the best statement of the contrast is to say, not that the Europeans have a law of civility where we do not, but that where the Europeans tend to have a law of civility, we tend to have a law of decency.) Like French and Germans, Americans make special provisions to protect police officers from abusive language, but American defendants in such cases are very frequently acquitted. ${ }^{319}$ As for the three Southern anti-dueling statutes, to the extent they are invoked at all, they have been assimilated into the mainstream of American jurisprudence. ${ }^{320}$

315. See, e.g., Cushing v. General Time Corp., 549 F. Supp. 768, 770 (N.D. Ala. 1982) (holding that "insults" and "indignities" do not give rise to a cause of action in Alabarna).

316. See, e.g., R.A.V. v. City of St. Paul, 505 U.S. 377 (1992); 4 Charles E. TorCIA. WHARTON'S CRIMINAL LAW $\$ 511$ (15th ed. 1996).

317. See, e.g., Hooks v. State, 660 N.E.2d 1076, $1077-78$ (Ind. Ct. App. 1996) (upholding the conviction of the defendant for shouting obscenities at officers, where obscenities could be overheard by neighbors). A much discussed recent Michigan case, which ended in the conviction of a canoeist who had used obscenities within the hearing of children, deserves to be cited here. See A Canoeist Who Cursed Draws His Punishment, N.Y. TIMES, Aug. 24, 1999, at A13.

318. For cases involving sexual solicitation and obscenities, see 4 STUART M. SPEISER ET AL., THE AMERICAN LAW OF TORTS $\S 16: 5$, at 982-83 (1987). By Doering's count, $31.2 \%$ of the insults used by German women had sexual content-mostly involving women calling each other "whores" because of their sexual activity-and only $15.3 \%$ of the insults used by German men had sexual content. See DOERING, supra note 45 , at 25,116 . For women as the only partics calling their spouses' lovers "whores" or "adulterers," see id. at 35.

319. See 4 TORCIA, supra note 316, $\$ 511$, at 131-32; see also Michael G. Walsh. Annotation, Insulting Words Addressed Directly to Police Officer as Breach of Peace or Disorderly Conduct, 14 A.L.R.4th 1252, 1270-73 (1982).

320. In Mississippi, the statute seems to have dropped from litigation. The most recent case I can find is Tattis v. Karthans, 215 So. $2 \mathrm{~d} 685$ (Miss. 1968). See also Henry v. Pearson, 158 So. 2d 695 (Miss. 1963), rev'd sub nom. Henry v. Collins, 380 U.S. 356 (1965). Henry was a civil-rightsera case in which a Mississippi official brought a successful defamation suit; the verdict in favor 
Statutory law is not all we have, of course. There is also the common law of torts. The limits on American tort law, though, are stark. The United States does have one tort-law tradition of penalizing insulting language that looks a bit like what we find in Europe. This is the practice, very vigorous once upon a time, of requiring common carriers, innkeepers, and public utilities to show courtesy to all comers. Especially in the late nineteenth century, American courts often held common carriers liable when their agents used just the sorts of epithets that show up in the European law of insult: "deadbeat," "swindler," "lunatic," "big fat woman." 321 This cause of action has largely vanished from American tort practice, though, even if it is occasionally relied upon by courts today. ${ }^{322}$ Even in its heyday, it had features that made it look quite different from the German or French law of insult. It never extended to cover "mere discourtes[ies]" of the kind sometimes actionable in Germany. ${ }^{323}$ Like other corners of American law, this law of insult was always something of a law of decency, focusing on "profane or indecent" language. ${ }^{324}$ Most of all, of course, the setting of the common carrier is worlds away from the duelist's encounters that informed European insult law. Where European law has always aimed to guarantee respect for honorable persons in all their daily doings, American law has aimed more at guaranteeing access in certain broadly commercial contexts. ${ }^{325}$ The difference is a sharp and continuing one: Down to this day, Americans can see a sign that reads "No Turks Allowed" as fundamentally

of the plaintiff was later reversed by the Supreme Cour. The scanty Virginia jurisprudence makes the statute essentially one of the ordinary fighting-words type. See Sanderson v. Colonial Williamsburg Found., [no docket number in original] 1990 Va. Cir. LEXIS 65 (Va. Ct. App. May 1990). But see, e.g., Pulliam v. Allen, 466 U.S. S22. 525 (1984): Old Dominion Branch 496 v. Austin, 418 U.S. 264, 282-87 (1974) (reversing the application of Virginia's statute in a defamation action in which federal labor law protected abusive language used against "scabs"): Wallace v. Chrysler Credit Corp., 743 F. Supp. 1228, 1231-34 (W.D. Va. 1990) (concerning the use of abusive language in repossession); Allen v. Burke, CIV. A. No. $81-00+0-A$, 1981 U.S. Dist. LEXIS 18456 (E.D. Va. June 4, 1981) (concerning an arrest under the Virginia statute); Zayre of Va., Inc. v. Gowdy, 147 S.E.2d 710, 713 (Va. 1966). West Virginia has the liveliest jurisprudence, but it too remains scanty, and involves causes of action familiar under the ordinary lor law of other states. See Estep v. Brewer, 453 S.E.2d 345, 346-50 (W. Va. 1994) (involving a defamation suit); Crump v. Beckley Newspapers, 320 S.E.2d 70, 75-92 (W. Va. 1984) (conceming privacy). But see Mauck v. City of Martinsburg, 280 S.E.2d 216, 219 (W. Va. 1981) (characterizing an insulting-word statute as punishing "vituperative epithets or traditional racial slurs").

321. KEETON ET AL., supra note $311, \S 12$ at $58 \mathrm{nn} .31-32$ (quoting from cases in which agents of common carriers used these insults, for which the carriers were found liable). For a recent discussion, see Cohen v. Varig Airlines, 380 N.Y.S.2d 450, $459-60$ (Civ. Ct. 1975). In one interesting case, Reed v. Maley, 74 S.W. 1079 (Ky. 1903), the court considered and rejected the extension of the reasoning in the common-carrier jurisprudence to cover a sexual approach to a woman of the kind covered by the German law of Sexualbeleidigung. See Jcan C. Love, Discriminatory Speech and the Tort of Intentional Infliction of Emotional Distress, 47 WASH. \& LEE L. REV. 123, 136-37 (1990). On Sexualbeleidigung, see supra notes 78-81.

322. See, e.g., Ricci v. American Airlines, 544 A.2d 428, 430-33 (N.J. Super. Cr. App. Div. 1988) (relying on the liability of common carriers for insults).

323. KEETON ET AL., supra note $311, \S 12$, at 58 n.31.

324. Id. $\S 12$, at 58 .

325. Though not generally speaking in shops. See id. $\$ 12$, at $58 \&$ nn. 38-39. 
offensive in a way that German jurists do not. ${ }^{326}$ Even when Americans have had a living tort law of insult, that law has presupposed the open marketplace as its setting.

In the rest of tort doctrine, the only sorts of nonviolent attacks that are commonly thought to call for a legal response in the United States are ones that damage reputation: defamatory and libelous statements. The classic account of Prosser includes some charming American huffiness over the very idea that mere incivility might give rise to tort liability:

[Outside the context of common-carrier liability,] defendants are not liable for mere insult, indignity, annoyance, or even threats, where the case is lacking in other circumstances of aggravation. The reasons are not far to seek. Our manners, and with them our law, have not yet progressed to the point where we are able to afford a remedy in the form of tort damages for all intended mental disturbance. Liability of course cannot be extended to every trivial indignity. There is no occasion for the law to intervene with balm for wounded feelings in every case where a flood of billingsgate is loosed in an argument over a back fence. The plaintiff must necessarily be expected and required to be hardened to a certain amount of rough language, and to acts that are definitely inconsiderate and unkind. There is still, in this country at least, such a thing as liberty to express an unflattering opinion of another, however wounding it may be to the other's feelings . . . . ${ }^{327}$

In the employment context in particular, Regina Austin notes that there is little restraint, under American law, on the use of abusive language. ${ }^{28}$ There are, it is true, a few egregious forms of misbehavior that may fall under the common-law category of "intentional infliction of emotional distress." But that tort, and the related tort of outrage, ${ }^{329}$ clearly cover

326. Contrast the German law discussed supra notes 200-201 and accompanying text.

327. KEETON ET AL., supra note $311, \S 12$, at 59 .

328. See Regina Austin, Employer Abuse, Worker Resistance, and the Tort of Intentional Infliction of Emotional Distress, 41 STAN. L. REV. 1, 1 (1988); see also KEETON ET AL.. supra note 311, $\$ 12,62$ (Supp. 1988) (discussing workplace regulations). But see 4 SPEISER ET AL., supra note $318, \S 16: 21$, at 1096-97 \& nn.86-91 (citing cases). Unsurprisingly, the German law is different. Section 193 of the Criminal Code instructs courts to take account of "justified interests" where workplace superiors are accused of insulting their subordinates. Nevertheless, the sense that dignity must be preserved applies to workplace subordinates in practice as it does to others. For the duty of persons of authority in the workplace to speak respectfully to their subordinates, in a way that respects their "Ehre" and "Menschenwürde," see, for example, BVerwG 1. Disziplinarsenat, Oct. 23, 1974, 1 D 28.74, JURIS ref. no. WBRE002558400; and compare BVerwG 1. Disziplinarsenat, Sept. 8, 1988, 1 D 70/87, JURIS ref. no. WBRE310098401. See also DOERING, supra note 45 , at 37 . Doering guesses that there are many unreported workplace cases. Nevertheless the tendency in Germany to regulate workplace interaction through addressing "mobbing" is powerful and represents a dramatic contrast with the United States.

329. For the proposition that the torts of outrage and intentional infliction of emotional distress are basically identical, see the cases cited in 4 SPEISER ET AL., supra note $318 . \$ 16: 13$, at 1016 n. 10 . 
behavior that is far more grievous than are the piddling shows of disrespect that can be sanctioned under the German law of insult, or even than those that can be sanctioned under French "policing" rules. ${ }^{330}$ We require considerable grievousness before any legal liability arises. ${ }^{331}$ If our doctrine of battery is something of a duelist's doctrine, the rest of the code of dueling never established itself in the common law: "[T]he trespass action for assault, which was a remedy designed to keep the peace, never was extended to words which were more insulting, unendurable, and generally provocative than blows." ${ }^{332}$ There are certainly cases in which the law of battery is used to impose liability for disrespectful behavior-notably cases with a tinge of racial conflict. ${ }^{333}$ Racial and ethnic insults, 100 , occasionally give rise to successful claims for intentional infliction of emotional distress. ${ }^{334}$ But those cases hardly amount to a developed body of civility law.

The general American resistance to creating a law of civility has also, and not least, marked American constitutional law. As all commentators on comparative hate-speech law have noted, our constitutional law makes free

330. See KeETON ET AL., supra note 311 . 12 , at 56:

The most cogent objection to the [law of intentional infliction of emotional distress] lies in the "wide door" which might be opened, not only to fietitious claims. but to litigation in the field of trivialities and mere bad manners. It would be absurd for the law to seek to secure universal peace of mind, and many interferences with it must of necessity be left to other agencies of social control. "Against a large part of the frictions and irritations and clashing of temperaments incident to participation in a community life, a certain toughening of the mental hide is a better protcetion than the law could ever be."

The drift of the law of intentional infliction of emotional distress has been to drop the historical requirement that there be some physical injury before recovery may be granted. See 4 SPEISER ET AL., supra note 318, § 16:5, at 968-70; Michael A. DiSabatino. Annotation, Civil Liabiliny for Insulting or Abusive Language, 20 A.L.R.4th 773-812 (1993). Nevertheless, even the cases that can be adduced to show that this shift has taken place fit within the American pattem. See, e.g., Hart v. O'Brien, 127 F.3d 424 (5th Cir. 1997), cert. denied. 119 S. Cl. 868 (1999) (holding that, under Texas law, liability for intentional infliction of emotional distress does not extend to mere insuits, indignities, threats, annoyances, or petty oppressions): Van Stan v. Fancy Colours \& Co., 125 F.3d 563 (7th Cir. 1997) (same under Illinois law): Dove v. PNS Stonss. 982 F. Supp. 1420 (C.D. Cal. 1997) (same under California law); Griswold v. Fresenius USA, 978 F. Supp. 718 (N.D. Ohio 1997) (same under Ohio law); Waldon v. Covington. 415 A.2d 1070 (D.C. 1980) (holding that physical consequences must be not unlikely to result or the defendant must enjoy a special relationship to the plaintiff such as that of common carrier or debtor-creditor): Tuggle v. Wilson, 282 S.E.2d 110 (Ga. 1981) (focusing on obscene language): S \& W Seafoods Co. v. Jacor Broad., 390 S.E.2d 228 (Ga. Ct. App. 1989) (involving incitement to violence); Harris v. Jones, 380 A.2d 611 (Md. 1977) (holding that emotional distress must be severe); Ford v. Hutson, 276 S.E.2d 776 (S.C. 1981) (requiring extreme outrage): Samms v. Eccles, 358 P.2d 344 (Utah 1961) (involving indecent behavior). Similar standards apply in the few cases in which recovery for ridicule is permitted. See 4 SPEISER ET AL., supra note 318. § 16:5, at 985-86.

331. See Love, supra note 321, at 137-38, 139 (discussing a case involving repealed solicitations to have sex and repeated verbal abuse).

332. KEETON ET AL., supra note 311 \& 12, at 57.

333. See, e.g., Fisher v. Carrousel Motor Hotel, 424 S.W.2d 627 (Tex. 1967) (holding a motor hotel club liable for battery for offensive treatment of African Americans).

334. See Love, supra note 321, at 128-35. 
speech a supreme value in a way that the law of Continental Europe does not. $^{335}$ The Supreme Court has indeed, after some decades of doubt, come close to saying that it is unconstitutional to make rudeness actionable. This was perhaps not always so. Chaplinsky v. New Hampshire ${ }^{336}$ is often cited as a decision that would have allowed regulation of rudeness, and it may be that it did. ${ }^{337}$ Even with respect to Chaplinsky, it is important not to let our attention wander too far from the facts. Chaplinsky partook of two very peculiar types of insult cases. It was a case in which the defendant called a city marshal a "damned Fascist." This means that it was, first of all, an exception of a very common type: a case involving police officers. Insulting police officers is a distinctive kind of offense-one that is much more commonly punished throughout the world than are other kinds of insults. ${ }^{338}$ Second, Chaplinsky, with its use of the epithet "Fascist," belongs within the special category of political-insult cases. Political-insult cases, especially ones involving accusations of Fascism, are common in Germany and France too. ${ }^{339}$ They have to do, it seems to me, less with the management of civility than with the governance of political debate. It is not at all obvious that the two sorts of problems are identical.

Whatever tendency toward permitting a law of civility there may have been in the Chaplinsky case, subsequent Supreme Court decisions have clearly taken a different turn, at least outside the schoolroom setting. ${ }^{300}$ One of these is, of course, Cohen v. California, ${ }^{341}$ known to everyone as the " $\mathrm{f}$ _ _ the draft" case. Cohen, decided in an era as politically troubled as the era of Chaplinsky, forbade California to criminalize a public utterance of obscenities. ${ }^{342}$ It is often viewed as marking the constitutional death of civility law in America. Here again, though, it is not clear that the case was really about civility. As I have emphasized throughout, public utterance of obscenity raises very different issues from disrespectful statements or gestures directed at an individual: Cohen is not about the law of civility, but

335. See, e.g., GEORG NOLTE, BELEIDIGUNGSSChUTZ IN DER FREIHEITLICHEN DEMOKRATIE (1992) (contrasting German and American treatments of free speech).

336. 315 U.S. 568 (1942).

337. See, e.g., Note, The Demise of the Chaplinsky Fighting Words Doctrine, 106 HARv. L. REV. 1129, 1131 (1993).

338. For a sample of cases in Germany, see HOHNEL, supra note 45, at 38-46; HAMBURGER ABENDBLATT, supra note 45. For collective insult of the police, see BayObLG [Bavarian Court of Appeals], NJW, 43 (1990), 921 (922) (F.R.G.). For France, see supra note 240. For current U.S. law, see supra note 319 and accompanying text.

339. See, e.g., DOERING, supra note 45, at 97 ("typischen SS-Mann" ["typical SS man"1); HOHNEL, supra note 45, at 12 ("alter Nazi" ["old Nazi"]). For France, see supra notc 246 and accompanying text. For "insulting" accusations of communism as common in the 1950s in West Germany, see DOERING, supra note 45, at 25.

340. On the permissibility of inculcating civility in the schools, see Bethel School District $v$. Fraser, 478 U.S. $675,681,683$ (1986).

341. 403 U.S. 15 (1971).

342. See id. 
rather about the law of decency. ${ }^{343}$ Nevertheless, it surely tells us something revealing about American culture that Cohen should have been read as a case about the law of civility. It was decided at a time, not only when longstanding restraints on obscenity were falling away, but also when everyday civility was in secular decline in many parts of the United States. In whatever way we read Cohen, it is clear that, with Hustler Magazine v. Falwell, ${ }^{344}$ the Supreme Court has taken a position that would make the German protection of personal honor-or even the French protection of personal honor-difficult to institute in America. As Justice Rehnquist said, proclaiming what is really the classically American view, citizens must tolerate insulting and even outrageous speech in order to provide adequate "breathing space" to the freedoms protected by the First Amendment. ${ }^{3+5}$ There is Gooding v. Wilson, ${ }^{346}$ another case from the politically charged 1960s, which invalidated the breach-of-peace statute under which an antidraft protester was convicted for using threatening language against police officers. Under Gooding, even statutes aimed at penalizing fighting words must face constitutional scrutiny. Not least, there is R.A.V. v. City of St. $\mathrm{Paul}^{347}$ the much-cited case striking down a hate-speech statute. There is, when you add all this up, a very great difference indeed between American and Continental European legal traditions.

The difference can perhaps best be captured by saying that we Americans balance different values than those balanced in Germany and France. Where German and French law balances the value of free speech against the value of honor, our law balances the value of free speech against nothing at all-unless it is the value of the suppression of violence (and sometimes the value of the suppression of indecency). The question of violence, indeed, does sometimes play something of the role in America that the question of honor plays in Europe. This tendency is implicit in the American "fighting words" doctrine, which limits liability for spoken words to cases likely to lead immediately to violence. The same tendency to look for a threat of violence shows in the comparison between our law of battery and assault and its German and French equivalents. The doctrines of Tätlichkeit and voie de fait that we have seen in German and French lawdoctrines that bear a common dueling-era origin with our doctrines of

343. Indeed, the willingness to regulate questions of decency shows up in a number of leading United States cases. See, e.g., Fraser, 478 U.S. at 675: City of Renton v. Playtime Theaters, 475 U.S. 41 (1986); FCC v. Pacifica Found., 438 U.S. 726 (1978); Young v. American Mini Theatres, 427 U.S. 50 (1976); cf. R.A.V. v. City of St. Paul, 505 U.S. 377, 385-88 (1992) (discussing permissible speech regulation revolving around "obscenity").

344. 485 U.S. 46 (1988). The contrast with French jurisprudence has been nicely drawn by Hauch, supra note 36, at 1219.

345. See Falwell, 485 U.S. at 52-55.

346. 405 U.S. 518 (1972).

347. 505 U.S. 377 (1992). 
assault and battery - form only one relatively minor part of the German and French laws of civility. ${ }^{348}$ In America they are practically all that we have. Even in the law of intentional infliction of emotional distress we still have a strong tendency to look for physical injury before we will impose liability. ${ }^{349}$ Lacking a category of honor as a protectable interest, Americans are led to penalize only behavior that threatens to assail bodily integrity.

For honor is truly absent from our legal thought-world. By contrast with Germany and France, American law has, it must be emphasized, remarkably little to say about norms of hierarchical respect. As we have seen, German law revolves around the showing of "lack of respect or disrespect" in ways that assume that the fundamental problem of human relations involves the assertion of hierarchical superiority by one person over another in the outward show of respect. That is, indeed, what makes the German law a law of civility and not a law of decency. American law is just different. The difference can be nicely captured by means of the sociology of Erving Goffman, whose accounts of the social psychology of personal interaction are widely cited. As Goffman presents it, everyday "civil" interaction is heavily informed by our sense of social hierarchy. Everyday interaction is a compound of "deference and demeanor," closely tied to social rank and social standing: "Deference images tend to point to the wider society outside the interaction, to the place the individual has achieved in the hierarchy of this society. Demeanor images ... pertain ... to the way in which the individual handles his position [in rank-ordered society] ...."350

To Goffman, all interpersonal interaction is, in the end, largely about rank-about relative status differences between the persons involved. ${ }^{351}$ This idea that there is a consciousness of rank in everyday interpersonal relations is easy to apply to the sorts of rudeness that we see in the case law on insult, and it can help us grasp what is going on in the German law I have described. Calling another person $d u$ can indeed be understood as a rank-oriented offense-as a refusal to show respect. French norms of politesse are also largely concerned with the showing of rank-oriented

348. According to Doering's figures, insults involving a Tätlichkeit alone amounted to only about five percent of the cases he surveyed, and ones involving both a Tätlichkeit and some verbal abuse amounted to only about three percent. See DoERING, supra note 45 , at 22. Presumably. those figures considerably exaggerate the percentage of cases involving Tätlichkeiten, since such cases undoubtedly end up in court in greatly disproportionate numbers.

349. See supra note 330 and accompanying text.

350. GOFFMAN, supra note 30 , at $82-83$.

351. To be sure, only largely: Goffman distinguished between "symmetrical" and "asymmetrical" interaction. See id. at 52. Nevertheless, the common impression that Goffman analyzed society in fundamentally hierarchical terms is not false: His strong emphasis was indeed on the "asymmetrical" style of interaction. 
respect in just the same way. ${ }^{352}$ Nothing of the kind is to be found in American law-pace Professor Post. ${ }^{353}$

352. See supra notes $288-289$ and accompanying text.

353. I think it is imporzant to state my disagreement both carefully and strongly. Post has written a number of admirably argued papers in which he has tried to demonstrate that a variety of intentional torts, especially defamation, effectively incorporate norms of civility into the law. Post points to the recurring appeals to "community norms" that feature in the adjudication of these torts. See, e.g., Post, supra note 7, at 120. These community norms, he argues, are inevitably norms of "civility." See id. at 55-56, 58, 81-84, 116, 127-29. 132-33. 136, 151. "Civility." in tum, Post describes by reference to the same sociology of Erving Goffman that I have employed in this Article. See id. at 54-55, 62-63, 72-73. Adjudication of the tort of defamation and of like torts, must, he concludes, represent efforts to maintain intact the "chain of deference and demeanor," to safeguard the integrity of the fabric of civility in socicty.

Post makes some superb arguments. See, e.g., id. at 73-74 (analyzing the mystery of the rebroadcast of private facts in privacy tor litigation). He is by no means extreme in the views he presents. He does not deny that American law requires a high degree of offensiveness before intervening. See id. at 65-66. Nevertheless, his argument is misleading. and indeed wrong. in ways - that must be brought out. A comparison with Germany and France shows. I think, what societies that are organized around "deference and demeanor" look like and highlights how different the United States is. Strikingly enough. Post adopts the sociology of Elias. which was developed to account for Continental European civility, and applies it to his account of the United States. See Post, supra note 7, at 716. Yet, of course, it is the burden of my Article to show that such casual application of European sociology to American circumstances is misguided.

The contrast between Post's America and the Europe that I have described here shows most dramatically, perhaps, in his acknowledgment that Goffman's sociology cannot easily be used to describe the American law of defamation. Post writes:

A preliminary objection to this concept of reputation as dignity is that defamation law

will not impose liability for breach of a civility rule unless there has been a

"publication to a third party," whereas Goffman makes clear that rules of deference

and demeanor are especially characteristic of face-to-face interactions .... .

Id. at 710. Post tries to deal with the difficulty in a characteristically elegant way, arguing that the presence of third parties allows for a social judgment of whether. in effect. the act of incivility in question was justified by the "unworth[iness]" of its target. See id. at 711. Yet I think Post is simply trying too hard; a close look at Germany and France shows that there are societies that comprehend the legal significance of face-to-face interaction in a way that fits into Goffman's analysis much more comfortably. Post is really misapplying Goffman to the American case.

That Post can do so, I suggest, is the result of circularity in his argument: He defines "community" as made up of norms of civility, only to conclude that where there is "community." there is civility. This circularity shows paricularly in his use of Goffman's sociology. Goffman. when he spoke of deference and demeanor, offered a definition of civility. Post takes this definition and uses it as though it were a description of a feature present in equal degree everywhere. Yet nothing in Goffman's definition of civility implies that there must be equal degrees of civility in all social settings. My survey has suggested the contrary. Gofrman's may be the right way to talk about civility, but there is a lot more civility. as defined by Goffman. in other societies than there is in the United States. Even supposing Post is right when he says that our tort law incorporates American norms of civility, he will prove little until he can demonstrate that there are American norms of civility. Citing Goffman's definition demonstrates no such thing.

Moreover, the direct comparison with Germany shows us another weakness in Post's account of how norms of civility are incorporated into American law. Even if there are widespread norms of civility, as defined by Goffman, in America, they are by no means so directly incorporated into legal doctrine as German norms are. As I have shown. the logic of the German doctrine of the law of insult is notable for its resemblance to the logic of civility as described by Goffman. Civility is about Achrung for Goffman, about showing respect. The German law of insult is about Nichtachtung oder Mißachtung. "lack of respect or disrespect." see supra text accompanying note 45 . German doctrine meshes directly with the dynamic of civility. The same simply cannot be said about American legal doctrine, and to the (considerable) extent that doctrine reflects underlying social norms, that is a revealing fact. It may be the case, as Post 
To say that America has absolutely no law of civility is to say too much. But to say that in general America has no law of civility-especially as compared with a country like Germany-is to make the right generalization.

\section{LEVELING UP/LEVELING DOWN}

That generalization, in turn, rests on a larger one. Standing behind both German and French attitudes toward the regulation of civility is something else: a commitment to the broad distribution of "honor" or "dignity" throughout society. This is a commitment, it deserves emphasizing, that goes far beyond the civility problem that I touch on in this Article. Continental European law is characterized by a very wide-ranging tendency to assert the importance of maintaining "a minimum of honor" 354 for all.

It is this tendency, deeply rooted in cultural tradition, to guarantee a "minimum of honor" that has established the conditions for hate-speech legislation as it exists in France and Germany. In both countries, the development of a body of hate-speech regulation has proven relatively easy because in both countries the regulation of hate speech fits comfortably into the longstanding tradition of the law of insult. The law of both countries retains the marks of an old body of doctrine aimed at providing legal protections for aristocratic honor; and the presence of that tradition has meant that, as the problems of accommodating foreign populations have grown, the law of both France and Germany has found a natural rubric ${ }^{35 s}$ for the protection of the honor of what are perceived to be outsider populations as well. That is not to say that hate-speech regulation as it has

suggests, that finders of fact in America apply norms of respect when they look to "community norms." But it surely remains important, and revealing, that American legal doctrine has never developed the Goffman-like forms of legal argument that Germany's has. The contrast suggests very strongly that norms of respect simply do not matter as much in the American legal world as they do in Germany-a conclusion borne out by a comparison of many facets of American and German law.

Pace Professor Post, then, I say again that the right generalization is that America has, for all practical purposes, no law of civility comparable to the German law of insult.

354. STARK, supra note 14, at 26. For European provisions sanctifying "honor" or "dignity," see, for example, Cost. an. 3, 1 (Italy). For more recent examples in the constitutional corpus, see BANGL. CONST. art. 31; BELG. CONST. art. 23; PORT. CONST. art. 26; CONSTTTUCIÓN [C.E.] art. 18 (Spain) (right to honor); TURK. CONST. art. 27; LEY ORGÁNICA DE 5 MAYO 1982 (Spain); CODE DE DROIT CANONIQUE 1983 can. 220; U.S.S.R. CONST. art. 14; European Convention for the Protection of Human Rights and Fundamental Freedoms, Nov. 4, 1950, 213 U.N.T.S. 222; and UNIVERSAL DECLARATION OF HUMAN RIGHTS, G.A. Res. 17, U.N. GAOR, 3d Sess., at 71, U.N. Doc. A/810, art. 12 (1948). These examples are assembled and discussed in BERNARD BEIGNIER, LE DROIT DE LA PERSONNALITÉ 78-79 (1992); and BEIGNIER, supra note 13. at $90-91$.

355. Quite fittingly, indeed, a "rubric." "Rubrics" were the red-letter subject headings for the various texts in the Roman legal corpus in the Middle Ages. As with those rubrics, the rubric of "honor" has provided a natural category for reasoning about dignity. 
developed in these countries is flawless. As I have tried to show, the practice of civility in these countries remains rooted in forms of the show of respect that can seem quite incongruous when translated into contemporary legal norms. The point is only that dignity, as a value, pervades these postaristocratic systems so much that dignitary law of some kind is more easily fashioned in France and Germany than it is in the United States. ${ }^{336}$

This pervasiveness of dignitary values also shows, it is worth noting (if only in passing), in the French and German approaches to sexual harassment. Sexual harassment law, which can also be thought of as law for the accommodation of an outsider population, is in its infancy in Europe. But, to the extent that it exists, it has been framed in distinctly dignitary terms in northern Europe. ${ }^{357}$ Once again, that does not mean that European sexual harassment law is likely to be flawless. European traditions of sexual respect, as we have seen, are not likely to appeal to many feminists; ${ }^{338}$ and at least one German feminist has already argued passionately against the idea that sexual harassment law should revolve around "dignity." 339 The practice of speaking in dignitary terms is, however, very deep-seated in Continental Europe, and the contrast with the United States is very strong. It is, I suggest, a contrast that shows once again how powerful is the Continental tendency to accommodate outsiders by according them "social honor." These Continental systems, in short, have human "dignity" today largely because they had personal "honor" in the past.

Let me try to frame this claim as clearly and carefully as possible. In particular, I would like to make three points clear: First, by saying that

356. For observations that are in some ways parallel, see PHILIPPE D' IRIBARNE, LA LOGIQUE DE L'HONNEUR: GESTIONS DES ENTREPRISES ET TRADITIONS NATIONALES (1989), which argues that pattems of behavior in French factories reflect old regime traditions of honor that are absent in the United States.

357. The German sexual harassment statute is framed in expressly dignitary terms. See Beschäftigtenschutzgesetz [Employee Protection Law], v. 24.4.1994 (BGBl. I S.1412-13) (F.R.G.) (Art. 10 of the 2. Gleichberechtigungsgesetz [Second Law Guaranlceing Equal Rights]) (grounding the law of sexual harassment in dignity). So, notably, is the European Union directive on the subject. Compare MICHAEL RUBENSTEIN. THE DIGNITY OF WOMEN AT WORK (1988), the report that provoked European Union activity. Although the French sexual harassment statute is not framed in dignitary terms, it is striking that French case law has introduced. in an almost instinctive way, consideration of dignity into the jurisprudence. See RUS 8-9/93 no. 842 ("comportement ayant pu affecter la pudeur ou la dignite") ("behavior that may have had an effect on the sense of shame or dignity"): Thierry Garé. Séduction ou Harcèlement. LA SEMAINE JURIDIQUE EDITION GÉNERALE, Mar. 11, 1998, at 445 ("ni indecents, ni humiliants, ces actes n'ont pu porter atteinte à la dignité de la plaignante") ("neither indecent nor humiliating, these acts cannot have constituted an affront to the dignity of the plaintiff'): Françoise DekeuwerDefossez, Le harcèlement sexuel en droit français: discrimination ou atteinte à la liberté?. JURIsClasseUR PERIODIQUE, 1993 I 3662, at 137, 138 (1993) ("En celte fin de XXe siècle. le harcèlement sexuel est apparu insupportable parce que contraire a la dignire humuine ....”) ("Here at the end of the 20th century, sexual harassment has come to seem unacceptable because it is contrary to human dignity ....").

358. See supra notes $80-82$ and accompanying text.

359. See generally BAER, supra note 81 (arguing that the American antidiscrimination model. with its focus on equality, is preferable). 
modern European civil dignity grows largely out of premodern aristocratic honor, I do not mean to suggest that Germany and France are still aristocratic or hierarchical societies. To be sure, there are still aristocrats in Continental Europe, and Germany in particular remains a society that impresses all Americans as quite hierarchical in spirit. Nevertheless, the old regime is truly dead and gone in both Germany and France, and a commitment to egalitarianism has truly established itself. What has happened is not that the old world has survived, but that a grammar of honor and dignity still undergirds both the German and French law of interpersonal respect. Dignity became the stuff of the law of respect during an era of aristocratic ascendancy. It remained the stuff of that law even during the Fascist era, and it has remained the stuff of that law down to the present, as the aristocratic coloration of the law has faded. It is not that there has been a literal "persistence of the old regime," to borrow Arno Mayer's famous phrase; ${ }^{360}$ rather, it is that there has been a persistence of old assumptions about what matters most in the social world. When Germans and Frenchmen reasoned about the law 150 or 200 years ago, they started from the assumption that honor mattered. They have, in effect, never stopped reasoning that way. ${ }^{361}$

Second, I do not mean to endorse the view that "civil" interaction always somehow involves hierarchical status-competition. This is the view associated with Erving Goffman, who often wrote as though all human interaction involved some effort at one-upmanship-that we are always trying to elbow each other out of the way in a race for honor. Such a picture of human interaction is, I believe, false: There is such a thing as authentically egalitarian interaction. Indeed, on both sides of the Atlantic, we observe a great deal of authentically egalitarian interaction. What matters, though, is that even the most unimpeachably egalitarian interaction takes place against the background of a notional scale of hierarchical ordering. Two persons may interact as equals at a high level of status, or as equals at a low level of status. In either case, they operate against the

360. ARNo J. MAYER, THE PERSiStenCE Of THE OLd REGIME: EuROPE tO tHe GREAT WAR (1981).

361. This is a pattern that can be nicely captured by borrowing the language of the phenomenologist and sociologist Alfred Schütz. As Schütz presented it, interpersonal interaction in every society drew on the "stock of knowledge" of the society in question. This meant that social roles and patterns and behavior were inevitably informed by certain "taken-for-granted" pieces of knowledge, acquired first in the family setting, and later from a whole host of institutions that trained and coaxed the individual: "For in [historical societies| the transmission of socially relevant knowledge is ... to a great extent independent of subjective relevance structures ... and constitutes a taken-for-grantedness [Selbstverständlichkeit] firmly anchored in the social structure ...." 1 ALFRED SCHUTZ \& THOMAS LUCKMANN, THE STRUCTURES OF THE: LIFE-WORLD 293, 293 (Richard M. Zaner \& H. Tristran Engelhardt, Jr. trans., 2d ed. 1973). Germany and France are no longer aristocratic societies. But certain patterns of respectful behavior that were "taken for granted" in earlier centuries are still taken for granted today. Thıs has had, as I have tried to show, great shaping force in the law. 
background assumption that human society tends toward hierarchy. The hierarchical element in interpersonal interaction lies in that background assumption, not in the actual dynamic of any particular interaction. Hierarchy belongs to the Vorverständnis, the unspoken taken-forgrantedness ${ }^{362}$ of a given interaction, not to the character of particular acts performed in the course of that interaction. Thus, it is my claim that there is an authentic egalitarianism in European dignitary cuiture, but that it is a high-status egalitarianism, played out against a background assumption that human society falls naturally into the high and the low. Thus, current European egalitarianism is, once again, reminiscent of the old world of dueling. A century ago, only status-equals would duel-and it goes without saying that they were high-status-equals. ${ }^{363}$ Today, it is the deep ambition of European dignitary thinking to make all persons high-status-equals in just the same way.

Third, by focusing on the aristocratic sources of the law of interpersonal respect, I do not mean to claim that all honor, in the European tradition, is aristocratic in origin. Historically, members of European craft guilds also had a sense of their honor, as did, for example, the recipients of academic degrees. Guild honor in particular has clearly survived in Europe; ${ }^{364}$ and indeed, I believe that the proper analysis of European economic regulation still must begin with a grasp of the tradition of guild honor-of Weberian "Standesehre." 365 A full-scale description of European societies as honor cultures would thus go beyond the problem of aristocracy. Nevertheless, within the narrow realm of "respectful" interpersonal relations, it is indeed the aristocratic tradition that matters most in Europe.

And it is the relative absence of an aristocratic tradition that lies at the heart of the American divergence from the European pattern. "Politeness from arrogance" has vanished too thoroughly in the United States. The consequence is that the United States, on the one hand, and France and Germany, on the other, have followed divergent paths of development in their march toward social egalitarianism as we see it today: Germany and France have leveled up; the United States has leveled down.

362. See Hans-Georg Gadamer. TRUTH AND Method 262 (Gamell Barden \& John Cumming trans., Crossroad Publishing Co. 1986) (1960):

[U]nderstanding means, primarily, to understand the content of what is said, and only secondarily to isolate and understand another's meaning as such. Hence the first of all hermeneutic requirements remains one's own foreunderstanding [Vonverständnis]. which proceeds from being concerned with the same subject....

Thus the meaning of the connection with tradition... in our historical. hermeneutical attitude, is fulfilled in the fact that we share fundamental prejudices [Vorurteile] with tradition.

363. See supra note 208 and accompanying text.

364. See, e.g., D'IRIBARNE, supra note 356, at 85-94.

365. See WEBER, supra note 91, at 534-35. 
Strikingly enough, we can find language in the great tradition of social thought that describes each of these paths, the American and the Continental European, separately. What we cannot find is any account that describes both.

Thus, the path that we see the United States taking, the path of leveling down, is one that has often been identified as the only possible one. Hume, Tocqueville, Proust, Marshall, and others have imagined that all modern egalitarian societies must be societies without any developed forms of politesse. As Hume put it:

Where power rises upwards from the people to the great, as in all republics, [thè] refinements of civility are apt to be little practised, since the whole state is, by that means, brought near to a level, and every member of it is rendered in a great measure, independent of another.... But in a civilized monarchy, there is a long train of dependence from the prince to the peasant, which ... is sufficient to beget in every one an inclination to please his superiors.... Politeness of manners, therefore, arises most naturally in monarchies and courts ... ${ }^{366}$

Tocqueville, too, associated politeness with aristocratic society and did not think it could survive in a democratic world:

Veritable dignity of manners consists in showing oneself always to be in one's place, neither too high, nor too low; this is what the peasant aims for as much as the prince. In democracies, all places seem doubtful, and in consequence manners in a democratic society, while they are often proud, are never dignified. Moreover, they are never well regulated or truly cultivated [ni bien réglées $n i$ bien savantes]. ${ }^{367}$

Proust employed his own kind of elegiac salon wit in asserting the same point, with ironic reservations:

[I]t seems that, in an egalitarian society, politeness would disappear-not, as is commonly believed, for lack of education, but because certain persons would abandon the deference which is

366. David Hume, Of the Rise and Progress of the Arts and Sciences, in 1 ESSAYS, MORAL. POLITICAL, AND LiTERARY 109 (London, T. Cadell 1772) (1742).

367. 1 ALEXIS DE TOCQUEVILle, DÉMOCRATIE EN AMÉRIQUE 269 (J.P. Mayer \& Max Lerner eds. \& George Lawrence trans., Easton Press 1966) (1835). Compare also the reflections of James Fenimore Cooper while

posing as a European visitor in Notions of the Americans .... "There has been so singular a compound of intelligence, kindness, natural politeness, coarseness and even vulgarity, in many of these persons, that I am often utterly baffled in the attempt to give them a place in the social scale."

CMIEL, supra note 9 , at 66. 
owed to prestige, and which must have an element of fancy about it if it is to be effective, and above all because other persons would abandon the graciousness which one gives liberally and which one refines when one senses that that graciousness is of infinite price to the person who receives it-a price which however would suddenly fall to nothing in a world founded on equality, like the price of everything that is founded merely on relations of trust. But this disappearance of politeness in a new society is not certain, and we are sometimes too disposed to believe that existing conditions are the only ones possible.... After all, politeness in an egalitarian society would not be a greater miracle than the success of railroads and of the military employment of the airplane. ${ }^{368}$

Marshall and Bottomore, too, in their Citizenship and Social Class, thought that real democracy could be achieved only through the elimination of status differences. ${ }^{369}$ All of these men described something like what the United States has progressively experienced. ${ }^{370}$

What France and Germany have experienced, by contrast, is better described by a different line of interpretation, one we can find in Rudolf von Jhering, Max Weber, Norbert Elias, and the many followers of Elias today. All of these spoke of leveling up. ${ }^{371}$ To Jhering, writing in the 1880 s,

368. PROUST, supra note 280 , at $746-47$.

369. See T.H. MARSHALI \& TOM BOTTOMORE, CITIZENSHIP AND SOCIAL Class 33 (1992). They write,

Equality of status is more important than equality of income. Even when benefits are paid in case, this class fusion is outwardly expressed in the form of a new common experience. All learn what it means to have an insurance card that must be regularly Id. stamped ... or to collect children's allowances or pensions from the post office.

370. See William IAN MHLer, The ANatomy OF Disgust 206-34 (1997). This work, with its treatment of contempt in "democracy" tout cour, belongs perhaps to the same camp. Democracies, as I have tried to show, differ.

371. The same idea is also to be found among sociologists of fashion. who (like Jhering in the passage cited in the following note) have seen the basic dynamic of fashion as involving imitation of the higher orders by the lower. For critical discussion of this line of argument, see ALAN HUNT. GOVERNANCE OF THE CONSUMING PASSIONS: A HISTORY OF SUMPTUARY LAW $49-57$ (1996). I cannot discuss here the subtle observations of Edward Shils, but they deserve to be quoted. Shils commented on Elias:

The phenomenon of das sinkende Kulturgut was noticed by German writers on late medieval society, and a parallel phenomenon was observed by Max Weber in his studies of Indian society. He called it "brahmanization." This theme has been treated by Professor M.N. Srinivas in his studies of "sanskritization." This assimilation of elements of the value systems of higher classes and castes by lower strata is not. however, identical either in quality or extent with the growth of the sense of fundamental affinity which characterizes modem society.

EDWARD SHIIS, CENTER AND PERIPHERY 14 n.5 (1975). Explaining this "fundamental affinity," he continued:

To a greater extent than ever before in history the mass of the population in modern Westem societies feel themselves to be part of their socicly in a way in which their ancestors never did. Just as they have become "alive" and hedonistic. more demanding of respect and pleasure, so, too, they have become more "civilized." They have come to be parts of the civil society with a feeling of attachment to that sociery and a feeling 
the drama of shifting civility norms was the drama of the "mad rush of class vanity and class jealousy":

The other classes have never rested until they have succeeded, as far and as well as they are able, in getting possession of whatever the higher classes have invented for themselves. Just as a new fashion in dresses, which first pops up among duchesses, finally works its way down to the wives of craftworkers, so it is also with the forms of politeness. ${ }^{372}$

Or as Elias carefully put it: "[P]rofessional bourgeois society, in everything that concerns social conduct, takes over the ritual of courtly society without developing it with the same intensity." ${ }^{373}$ Neither author was concerned with the law of civility - not even Jhering, who did not really regard civility as properly regulable by law. But what both describe captures quite nicely what has gone on in France and Germany.

These two lines of sociological argument-the line, we might say, of Hume, and the line of Elias-seem irreconcilable. On the one hand, we have the claim that egalitarianism destroys civility; on the other, the claim that egalitarianism generalizes civility. They are not irreconcilable, however. Different as the leveling-down and leveling-up interpretations of the course of the development of civility in egalitarian societies sound, the truth is that these different authorities are simply describing what have turned out to be different paths of social development. ${ }^{374}$ The error is in claiming that there can be only one egalitarianizing tendency. In fact, in the post-Revolutionary Western world, there have been at least two.

of moral responsibility for observing its rules and sharing in its authority... Nonetheless, this greater incorporation carries with it also an inherent tension. Those who participate in the central institutional and value systems-who feel sufficiently closer to the center now than their forebears ever did-also feel their position as outsider, their remoteness from the center, in a way in which their forebears probably did not feel it. The modern trade union movement . . . illustrates this development.

Id. at 14-15. These are observations that open the way to much more wide-ranging discussion than I can undertake here, as are Shils's accounts of deference as reflecting the "central" ideas and institutions of a given society. See id. at 239-55.

372. 2 JHERING, supra note 25 , at 524.

373. EliAS, supra note 24, at 504. For doubts about this "trickle-down" theory of culture, sec Peter Burke, Popular Culture Between History and Ethnology, 14 EthiNologia EuRopalia 5 (1984).

374. It is odd how few commentators speak of the possibility that there are simply differences in the ways different societies have developed. There is Weber, who treats status-oriented sociely and market-oriented society as existing in fundamental tension with each other. For an attempt-I think an erroneous one-to distinguish different patterns of development in different societies, see WEBER, supra note 91, at 639. See also WEBER, supra note 205, at 270. Among more clegant writers, there is also Heine. See HEINE, supra note 293, at 499-501 (denying that the French pattern applied in either England or Germany). 


\section{EXCURSUS ON VIOLENCE AND MODERN HONOR CULTURES}

Personal honor has survived the process of democratization in northern Continental Europe-at least so far. Enough so that it is not wrong, in contrasting them with the United States, to describe Germany and France as modern honor cultures-although, to be sure, old-style "personal honor" has been undergoing a gradual and partial transformation into new-style dignity. To speak of Germany and France as honor cultures, though, is to raise a troubling paradox involving the place of violence in these societies. This is not a paradox that this Article can fully resolve, but it is one that it is too important not to be addressed at least briefly.

The troubling paradox is simply this: Our literature on traditional honor cultures assumes that a sensitivity to questions of honor goes hand in hand with a propensity to do violence. People who care about their honor are quick to explode. Correspondingly, honor cultures are, we usually think, violent cultures. This is a connection that has been made in analyses of the American South, where, down to this day, we see both high rates of civility and high rates of violence. ${ }^{375}$ It is also a connection that has been drawn in familiar analyses of such societies as those of medieval Iceland ${ }^{376}$ or of the contemporary Rif ${ }^{377}$-places where the love of honor has been connected with the practice of violence. ${ }^{378}$ There is, furthermore, a psychological literature that sees an abiding link between anger, violence, and the sense of having been shown disrespect. ${ }^{379}$ The literatures of anthropology, sociology, and psychology would lead us to expect that rates of violence in the Germany and France I have described should be comparatively high.

Yet the opposite is the case. Indeed, it is a datum of major importance in comparative law that rates of violence are low in northem Europe compared with those in the United States, or indeed in most of the world. ${ }^{380}$ How can this be?

375. For high rates of violence in the South, see FISCHER, supra notc 302, at 889-90; WYATT-BROWN, supra note 39, at 366-71; and Sheldon Hackncy, Southern Violence, 74 AM. HIST. REV. 906 (1969). See also Elliott Gom, "Gouge and Bite. Pull Hair and Scratch": The Social Significance of Fighting in the Southern Backcountr, 90 AM. HIST. REV. 18 (1985). For low rates of violence in 17th-century New England compared to the Chesapeake colonies, ste FISCHER, supra note 302, at 191. For the culture of violence in Virginia, see id. at 400-05.

376. See William IaN MILLER, BloOd-Taking aNd PEACEMaking (1990).

377. See Raymond Jamous, From the Death of Men to the Peace of God: Violence and Peace-Making in the Rif, in HONOR AND GRACE IN ANTHROPOLOGY 167 (J.G. Pcristiany \& Julian Pitt-Rivers eds., 1992).

378. See FLYNN, supra note 26, at 21-24, 47-49, 76-79, 116-20 (discussing the connection between insult and violence in various societics).

379. See AARON T. BECK, PRISONERS OF HATE: THE COCNITIVE BASIS OF ANGER, HOSTILITY AND VIOLENCE (1999); Jan Smedslund, How Shall the Concept of Anger Be Defined?, 3 THEORY \& PSYCHOL. 5, 13 (1993) ("Everyone has a right to . . be treated . . respectfully, and when this right is violated, there is anger.").

380. Indeed, the greater presence of viulence in American socicty has left its mark on the very legal doctrine that I have described in this Article. As we have seen. American tort doctrine 
This is a question that is too vast to be answered in this Article; answering it adequately would involve developing a full-scale explanation for northern Europe's pattern of violence. Nevertheless, the problem of the link between honor and violence is too important to be completely ignored. Accordingly, in this brief Part, I want to say a very general word about how European historical development produced the unexpectedly peaceable honor cultures that I have described. (I also want to reject one familiar answer-that of Norbert Elias-whose argument I address in the notes. $)^{381}$

displays a strong tendency to let conflicts slide into violence before it allows the law to intervene. Our "fighting words" doctrine demands that the threat of violence be palpable. Perhaps something similar can also be seen in the high profile of our torts of battery and assault. These too are torts in which, as their names indicate, we think of the possibility of violence as rising close to the surface; "quiconque touche," we still say in American law, "frappe." "to touch somebody is to hit him." Even our law of intentional infliction of emotional distress is a law that in practice tends to look for physical injury. It is American law, in short, that is framed by the expectation that the threat of violence is ever-present; we have the law that assumes that the great social problem is that people are likely to explode into acts of violence. German law, by contrast, secms to assume that questions of honor can be peaceably litigated-that persons with a keen sense of their personal honor will bring private prosecutions rather than immediately lash out.

381. In his much-admired work on "the civilizing process," Elias tried to explain the history of good manners in Europe by combining, in effect, Weber's theories with Freud's. Elias agreed with Weber that the tale of modem social history has largely been the tale of the decline of everyday violence. He departed somewhat, though, from Weber's emphasis on the political conflict between the state and its rivals to power. There had to be, Elias insisted, more to the successful suppression of violence than the mere promulgation of laws forbidding violent acts. Widespread social violence ends only when ordinary persons internalize norms of self-control. It is only when people have been trained to suppress their own violent affect that violent encounters become less prevalent in society at large.

This means, he thought, that the sociology of violence must rest on a knowledge of the history of human psychology, and it is just such a history that Elias tried to develop. Focusing on rules of decency-rules of table manners, rules requiring that we hide our bodily functions from others-Elias argued that the rise of "good manners" is a chapter in the history of the decline of violent behavior. The rules of good manners, he maintained, revolve largely around some of the most animalistic features of human existence: They forbid us, typically, to indulge publicly in acts associated with sexual desire and bodily functions. Their purpose is to encourage norms of selfcontrol by cutting at the root of our most violent animal instincts. Such rules, he claimed, first established themselves in the aristocratic societies of the 17th and 18th centuries. These werc societies in which learning self-control was indispensable for aristocrats who had to pursuc their advancement in court without resorting to violence. The kind of self-control that Weber had attributed to the bourgeoisie in his Spirit of Capitalism was thus in fact first to be found in the aristocracy. Only after the rules of decency had established themselves in aristocratic society werc they adopted among the bourgeois, especially of the 19th century, who needed to master selfcontrol for their own purpose, the purpose of capitalist accumulation.

At first blush, Elias's argument does seem to offer some basis for explaining the shape of modern European honor: Elias, of all sociologists, is the one who believed he could demonstrate that a heightened sensitivity to "civility" would bring with it a diminished susceptibility to violent impulses. Yet on close inspection, Elias's argument proves frayed and revealingly incomplete.

This is true, first of all, because Elias did not bring enough nuance to his account of good manners. Elias never distinguished between decency and civility, speaking in an undifferentiated way about "good manners." In fact, he drew essentially all of his examples from the realm of decency, leaving civility rules fundamentally undiscussed in his oeuvre. For my purposes here. this omission weakens Elias's study almost irremediably. Rules of decency, of the kind Elias discusses, do indeed aim to patrol the border between the human and the bestial; and to the extent that the bestial and the violent run together in human society, the history of decency can indeed be the sort of psychological history of the monopolization of violence that Elias set out to writc. It is 
Germany and France do indeed differ from the traditional honor cultures that are commonly discussed in our social science literature. This is not because violence was never a problem in these countries. Quite the contrary: The dueling aristocracy presented a much-deplored problem until 1914, and even after; honor did go along with violence in northern Europe for a very long time. Indeed, low-status Europeans participated in a culture of honor-obsessed violence too-often enough through their own forms of the duel, such as the knife fight. ${ }^{382}$

Much of what set these countries apart from traditional honor cultures, though, was something that emerges from the very story I have traced in this Article-something long ago identified by Max Weber: the commitment of European states to the monopolization of the legitimate use of violence. The monopolization of violence was a preoccupation of the European Continental monarchies from a very early date. What must be emphasized, though, is that this was a preoccupation, not because violence as such seemed objectionable. Premodern societies did not typically imagine that violence was anything other than an ordinary condition of life. The violence that European monarchies primarily sought to suppress was, first and foremost, violence that threatened to shake the monarchies' own grip on power. The monopolization of violence was not the product of some grand universal social-evolutionary tendency to guarantee peace and bodily integrity for all; it was the product of many centuries of European history during which the state's weak hold on power was frequently challenged by well-armed potentates. A monarchy like that of France, in the late Middle Ages and the first part of the early modern period, had to be deeply concerned with disarming rival claimants to authority; and consequently it developed what was at first a limited program of suppressing violence among the powerful-a program only much later extended throughout all of

relatively easy to write a history of human psychology that relates the problem of decency to the problem of violence. Rules of civilin, on the other hand, have to do, as I suggested earlier, with hierarchical ordering within human society. It is not nearly so easy to argue that rules of civility help clamp down on violent affect as it is to argue that rules of decency help clamp down on violent affect. Indeed, all of our psychological literature suggests the opposite. See supra notes 371-374 and accompanying text. If Elias has correctly identified the psychological mechanisms at work in the decline of European violence, how can we possibly account for Mississippi or Montenegro?

The answer, I would suggest, is that Elias was wrong in imagining he had identified universally operative psychological mechanisms. What he identified, as I suggest in the main text of this Part, were certain peculiar patterns of political development. It is not the case that encouraging civility discourages violence. It is the case that European monarchies both encouraged civility, as part of a larger effor to control the distribution of honor in their societies. and clamped down on aristocratic violence, as pan of a larger effort to guarantce their own hold on political power. See ELIAS, supra note 24, at 447-53, 518-24.

382. See Daniele Boschi, Homicide and Knife Fighting in Rome, in MEN AND VIOLENCE: GENDER, HONOR, AND RITUALS IN MODERN EUROPE AND AMERICA 128 (Pieter Spicrenburg ed. 1998); Pieter Spierenburg, Knife Fighting and Popular Codes of Honor in Early Modern Amsterdam, in MEN AND VIOLENCE, supra, at 103-27. 
society. Indeed, as historians of the duel have observed, dueling itself arose largely because sixteenth- and seventeenth-century aristocrats, who had long been strong and independent potentates, had progressively been denied the more threatening forms of violence that they had practiced in the late Middle Ages. Having been stripped of their private armies, walled castles, and military way of life, sixteenth-century aristocrats turned to dueling as a tamer form of violence.

I suggest that the low rates of violence we see in northern Europe today have to be traced, at least partly, to this long tradition of the monopolization of violence. The northern European states of the late twentieth century are the products of many centuries of efforts to monopolize the legitimate use of violence against challenges by (especially though not exclusively) an aristocratic class. One consequence of this history is an ingrained tradition of suppressing violence. Another effectively independent consequence is a tradition of bringing honor into the courts: Old insult rules designed to bring honor-conscious aristocrats into court have persisted and indeed given birth to new dignitary rules. In these modern honor cultures, generations of governmental efforts have succeeded in uncoupling honor from violence.

Elsewhere the same pattern is not to be found. Other societies-most especially American society-are just different. This arguably reflects, in the last analysis, nothing more complex than the relative absence of a Weberian monopolization of violence here. That absence, in turn, reflects the fact that the American state has never faced the kind of authentic challenges to its rule that have shaped its Continental European counterparts. While there has always been plenty of violence in the United States, that violence has rarely represented any significant challenge to the legitimate rule of the American state. Well-armed potentates are not part of our experience. It is, I propose, partly a consequence of the fact that we have never developed the full-scale commitment to the monopolization of violence that we see in northern Continental Europe.

Where traditional honor culture is to be found in the United States, it tends, accordingly, to display its traditionally high rates of violence. Indeed, if the account that I have sketched out in this Part is right, there is little reason to suppose that more civility in the United States would produce anything like northern Europe's low rates of violence. Those low rates of violence are, in large part, the result of a pattern of the monopolization of violence that our country has simply never seen.

\section{CONCLUSION}

All of this does not give us any certain information about the prospects for a law of civility in the United States. There is no reason to believe that any single social pattern is behind the success of a law of civility in various 
societies. Certainly there is no reason to believe that an aristocratic past must lie in the background of any modern regulation of civility, simply because such an aristocratic past lies in the background of the law of our near western European neighbors. As Proust said, in a world with railroads and military aircraft, who knows what else may come to pass? ${ }^{383}$ The comparative study that I have offered here does, however, show the centrality of social preconditions for the making of values like "respect," whatever those preconditions may be. Northern European societies do not just have pieces of dignitary legislation whose provisions can be meaningfully retailed in law review articles. They have deeply rooted social traditions of respect. Accounts of European law that are barren of description of those social traditions will never be correct.

Moreover, the strength of such social traditions is, in ways we would often prefer to forget, at odds with some of our philosophical ambitions. No amount of philosophy—no amount of Kant or Rawls—can make the clay of human society easy to work, and, dishearteningly, the clay of one place is often not much like the clay of another. Thus what one recent philosophical advocate of civility writes may be true, as far as it goes:

My point about manners ... is that whatever we must do in order to accommodate our ends to the ends of others, we must do something more in order to acknowledge the intrinsic value of others. Acknowledging a person's intrinsic value-treating her with respect-also requires that one treat her politely (considerately, respectfully). If we treat someone rudely, then we fail to treat her with respect .... ${ }^{384}$

This is admirable stuff, and people who live according to such norms are to be cherished. But in trying to understand the law, we must remember that such people will always be exceptions. If we want to talk practical sense about respect in society, we have to talk about human beings as they are, not about human beings as Kant would like them to be. The values of respect have established themselves in some societies and not in others. Where we find those values, they can be traced to social traditions that have little to do with high Kantianism.

By the same token, the values of respect, where we find them, can be traced to social traditions that have little to do with the high ideals of tolerance that have grown up since the Holocaust. European hate-speech

383. See supra note 368 and accompanying text.

384. Buss, supra note 3 , at 797 . Elsewhere. Buss is careful to make the argument that the sources of codes of civility in past hierarchy do not bear on the intrinsic merits of those codes. See id. at 809-10. True enough. I would maintain, though, that, whatever their merits. those codes are less likely to establish themselves in societies that do not have a comparatively strong tradition of social hierarchy. 
legislation is, indeed, as Friedrich Kübler carefully and correctly says, "largely a product of the second half of the twentieth century." 385 More broadly than that, the European legal culture of human dignity is largely a product of the second half of the twentieth century. But if we focus too exclusively on the last fifty years-on the era, so to speak, of European Reconstruction-we are likely to deceive ourselves about how such a dignitary culture became possible. The history of European dignity is much older than the post-Fascist era, and the underlying assumptions of European dignity have to do with grimmer matter than the great ideals of post-Fascist reform. Indeed, the Fascists themselves contributed significantly to the making of the honor cultures that we see in Continental Europe today. Today, meaningful dignitary practices are being wrought in Europe, but they are being wrought from the clay of human society, and it is coarse matter. What is more, the clay of American society is, as I have tried to show, different.

That does not mean that we can learn nothing from the study of places like France and Germany. At the very least, studying the Continental tradition does give us a somewhat richer sense of what is at stake in our debate over the regulation of civility. After all, what is at stake? One thing we might suppose to be at stake is the prevalence of violence in society. Mayor Giuliani's civility campaign in particular raises the hope that better everyday behavior will mean less violent crime. This is a hope that I have addressed only in the briefest way in Part IX, but it deserves emphasizing that what I have been able to say is not encouraging. Germany is indeed a place in which there is a link between law of civility and the suppression of violence. Elsewhere, too, there may really be a connection between rough manners and outbreaks of violence, and it is possible that non-German legal systems that are committed to cracking down on rough manners could also be legal systems that succeed more broadly in limiting violence. It is essential to recognize, though, that Germany is the product of many centuries of conflict between state and aristocracy-and many painful centuries at that. It is also essential to recognize that, in most societies we know, teaching people to believe in their right to respect is likely to make them more violent, and not less. The case of the American South, in particular, is not encouraging. For the South, it seems, is a region where people care about civility because they care about honor, but it is also a region where they explode into violence because they care about honor. Even if we could easily crack down on rough manners, we are not entitled to assume that we would thereby make America into Germany.

What is more, even if we could simply decide to abolish rudeness, I think this comparative study reminds us that there is something else at stake

385. Kübler, supra note 16, at 366 (emphasis added). 
that might make us hesitate to do so-something that was perhaps obviously there all along, but that is nevertheless easily forgotten: Our tradition of incivility is bound up with our peculiar form of egalitarianism. The American refusal to show respect to anybody is not just, as it were, a social refusal; it belongs to our sense of the political constitution of our form of egalitarian society. It is important to us, as political actors in everyday life, to refuse to show respect-to refuse to participate in what we perceive, more strongly than Europeans do, to be the hypocrisy of manners. In this sense we are the heirs of the great disrespecters of Antiquity, the Cynics, ${ }^{386}$ and some of the early Christians; ${ }^{387}$ and of the Quakers, too, who played such an important role in the formation of American social egalitarianism. ${ }^{388}$ And our free speech, to adopt a term from ancient cynic philosophy, tends to express itself as "parrhesia" - as speech that is not just about the sober expression of opinions, but also about the free and aggressive display of disrespect. ${ }^{389}$ I think the deep association between our incivility and our style of egalitarianism is perfectly obvious to every American, at least outside the American South. It is an association that somehow fails to rise to the surface, though, in our many discussions of the civility problem.

Part of what the comparison with France and Germany can do is underline this association between the politics of egalitarianism and the reach of the regulation of civility. What we see in these Western European neighbors is precisely a different political tradition of egalitarianism. France and Germany are countries that have experienced more or less violent

386. Diogenes, of course, by masturbating in public and refusing to defer even to Alexander the Great, is reported to have flouted rules both of decency and of civility. See A.A. Long. The Socratic Tradition: Diogenes, Crates and Hellenistic Ethics, in THE CYNICS 29, 33-38 (Bracht Branham \& Marie-Odile Goulet-Cazé eds., 1996) (masturbation); id. al 35 n.20 (encounter with Alexander the Great).

387. For early Christian rejection of the values of honor and deference, see WAYNE A. MEEKS, THE ORIGINS OF CHRISTIAN MORALITY: THE FIRST TwO CENTURIES 46-47, 62-63, 8687, 96 (1993). For New Testament passages calling for a rejection of practices of honor in the ancient Mediterranean world, see, for example, Marthew 5:11, 5:39 (tuming the other cheek): Matthew 23:1-12 (cultivating modesty); Mark 12:38-39 (distrusting the scribes); Luke 11:43 (cursing the Pharisees); Luke 14:7-11 (taking the lowest seat at a feast); and Luke 20:46 (avoiding the scribes). For the contrary, see Romans 13:7, which enjoins Christians to honor the honorable. Within Christian discourse, much of this problem is characterized under the New Testament

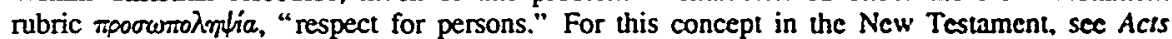
10:34; Romans 2:11; Colossians 3:25; James 2:1; and James 2:9.

388. For Quaker use of the "metoric of impoliteness," deliberately eschewing courteous forms, as an instrument of egalitarianism, see RICHARD BAUMAN, LET YOUR WORDS BE FEW: SYMBOLISM OF SPEAKING AND SILENCE AMONG SEVENTEENTH CENTURY QUAKERS (I983), cited and discussed in FISCHER, supra note 302, al 474.

389. On parthesia among the cynics, see Bracht Branham \& Maric-Odile Goulet-Caze. Introduction to THE CYNICS, supra note 386, at 13,17; and Long. supra note 386. at 35. For the wider range of meaning of this and other concepts of free specch in antiquity. sec Amaldo Momigliano, Freedom of Speech in Antiquity, in 2 DICTIONARY OF THE HISTORY OF IDEAS 253. 259-60 (Phillip P. Wiener ed., 1973). In the context of classical Athenian law in particular, see Stephen Halliwell, The Uses of Laughter in Greek Culrure, 41 CLASSICAL Q. 279, 288-89 (1991). 
egalitarian revolutions, just as we did. They have emerged differently from their revolutions, though. The French and German legal traditions were formed in societies in which visible and powerful aristocracies were the target of egalitarian movements, and they are both societies whose egalitarianism, in different ways, has involved extending membership in the aristocracy, in effect, to everybody. They are societies built on revolutionary redistribution of honor. This is true not only of the law, but also in what we may think of as the main arena of French civility regulation-education. ${ }^{390}$ This history has laid the groundwork for French and German hate-speech regulation, and it may yet lay the groundwork for a French and German law of sexual harassment that is dignitary in orientation. ${ }^{391}$ We have had, all in all, no visible and powerful aristocracy of the same kind in the United States, and our egalitarianism has taken a different turn. This has had many consequences outside the law of civility, my narrow topic here. But within that narrow topic it does have a consequence we should not forget: We are not going to find it easy to generalize respect in the United States; our incivility is not just an aspect of a rough social life that can be casually disengaged from the political traditions of our country. American incivility is woven into the cloth of the American egalitarian tradition. At the very least, this makes the campaign for more civility a difficult one.

390. Indeed, if we hoped to regulate civility through schooling, we would likely find it difficult to imitate the French example directly.

391. See supra notes 357-359 and accompanying text. 